\title{
EXAMINING THE 4G MOBILE STANDARD CONVERGENCE TO THE LTE STANDARD
}

\author{
by \\ Gurpreet Saini \\ A thesis submitted to the Faculty of Graduate Studies and Research \\ in partial fulfillment of the requirements for the degree of \\ Master of Applied Science in Technology Innovation Management \\ Department of Systems and Computer Engineering, \\ Carleton University \\ Ottawa, Canada, K1S 5B6 \\ September 2009
}

CCopyright 2009 Gurpreet Saini 


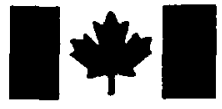

Library and Archives

Canada

Published Heritage

Branch

395 Wellington Street

Ottawa ON K1A ON4

Canada
Bibliothèque et

Archives Canada

Direction du

Patrimoine de l'édition

395, rue Wellington

Ottawa ON K1A ON4

Canada
Your file Votre référence
ISBN: 978-0-494-60230-0
Our file Notre référence
ISBN: $978-0-494-60230-0$
NOTICE:

The author has granted a nonexclusive license allowing Library and Archives Canada to reproduce, publish, archive, preserve, conserve, communicate to the public by telecommunication or on the Internet, loan, distribute and sell theses worldwide, for commercial or noncommercial purposes, in microform, paper, electronic and/or any other formats.

The author retains copyright ownership and moral rights in this thesis. Neither the thesis nor substantial extracts from it may be printed or otherwise reproduced without the author's permission.
AVIS:

L'auteur a accordé une licence non exclusive permettant à la Bibliothèque et Archives Canada de reproduire, publier, archiver, sauvegarder, conserver, transmettre au public par télécommunication ou par l'Internet, prêter, distribuer et vendre des thèses partout dans le monde, à des fins commerciales ou autres, sur support microforme, papier, électronique et/ou autres formats.

L'auteur conserve la propriété du droit d'auteur et des droits moraux qui protège cette thèse. Ni la thèse ni des extraits substantiels de celle-ci ne doivent être imprimés ou autrement reproduits sans son autorisation.
In compliance with the Canadian Privacy Act some supporting forms may have been removed from this thesis.

While these forms may be included in the document page count, their removal does not represent any loss of content from the thesis.
Conformément à la loi canadienne sur la protection de la vie privée, quelques formulaires secondaires ont été enlevés de cette thèse.

Bien que ces formulaires aient inclus dans la pagination, il n'y aura aucun contenu manquant.

\section{Canadä}


The undersigned hereby recommend to

the Faculty of Graduate Studies and Research acceptance of the thesis

\title{
EXAMINING THE 4G MOBILE STANDARD CONVERGENCE TO THE LTE STANDARD
}

\author{
Submitted by \\ Gurpreet Saini
}

In partial fulfillment of the requirement for the degree of

Master of Applied Science in Technology Innovation Management

Howard Schwartz, Department Chair

Stoyan Tanev, Thesis Supervisor

Thomas Kunz, Thesis Supervisor

Carleton University

September 2009 


\section{Abstract}

The mobile communication service providers have been using different digital mobile communication standards. As a result, the market has been geographically fragmented by the deployment of one of the two dominant families of standards, (i) the Global System for Mobile communication (GSM), or (ii) the Code Division Multiple Access (CDMA). Such fragmentation persisted in both second and third generation networks. However, the last few years have witnessed an unprecedented change in this pattern - major service providers have committed to a single standard known as Long Term Evolution (LTE). Within a very short period of time LTE has emerged as the fourth generation network choice for almost all providers.

This research study examines the phenomenon of the decisive convergence to a single mobile communication standard using a multi-level longitudinal case study of the LTE standard to explore the context, process and content of change associated with all relevant events and the stakeholders involved in them. The research produces a set of constructs that can be used to describe the convergence to LTE as well as applied to other similar phenomena in emerging information and communications technology open standards. The key contributions of the research are: i) validating a methodology that was previously used to study the adoption of an open standard to involve the phenomenon of technology convergence, ii) develop a set of constructs describing the evolution of LTE by taking into account the convergence phenomena, iii) provide insights that are relevant to top management teams of firms willing to engage in the development and adoption of emerging open standards in order to align their competitive and product development strategies. 


\section{Acknowledgements}

I would like to express my gratitude to my supervisors Professor Stoyan Tanev and Professor Thomas Kunz, for their guidance, support, patience and encouragement throughout this research. I am also thankful to Professors Tony Bailetti, Michael Weiss and Douglas King for their valuable feedback and constructive suggestions at various stages of the research.

I would like to take an opportunity to thank my family, friends and colleagues for their constant support and source of encouragement though out this journey. 


\section{Table of Contents}

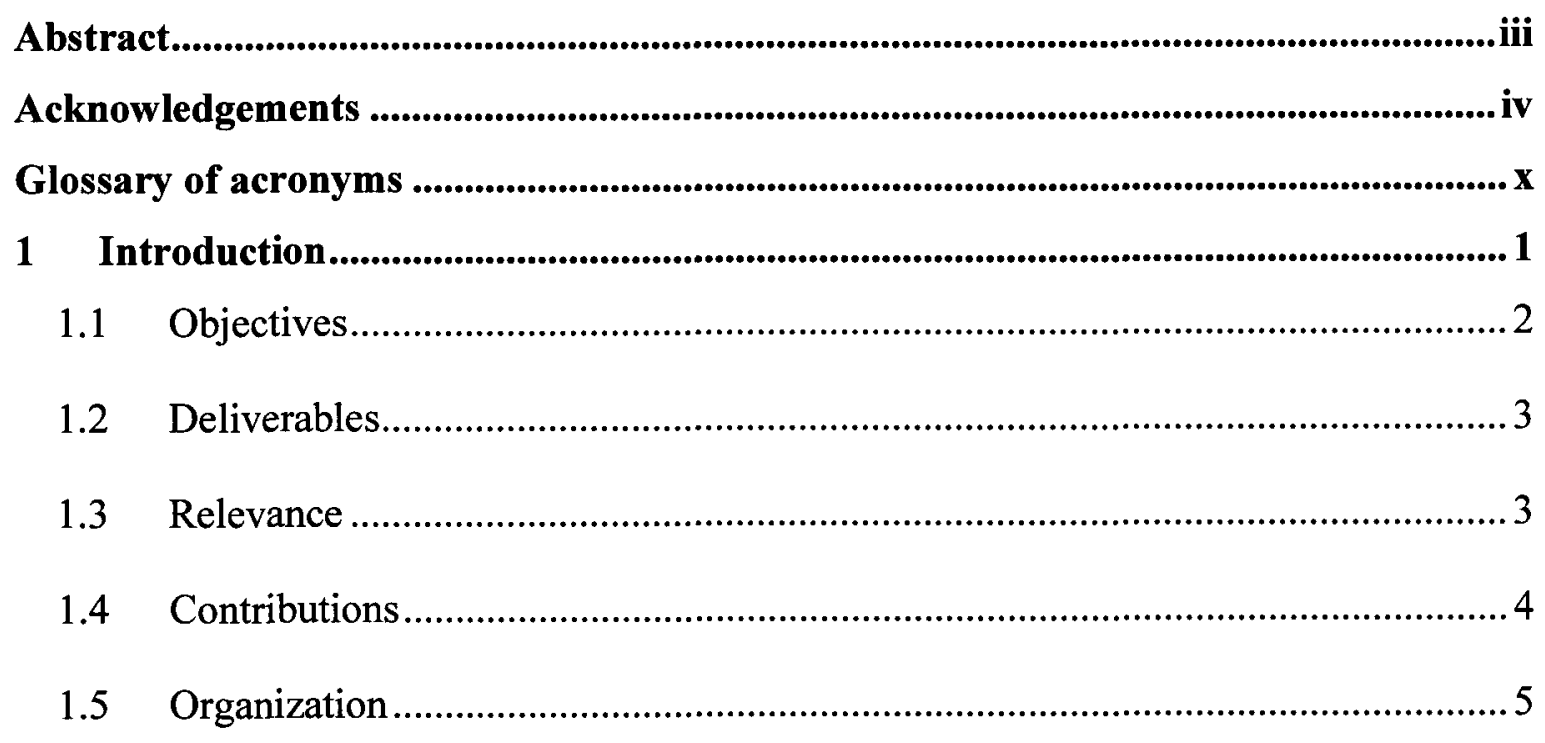

2 Literature review ..........................................................................................................6 6

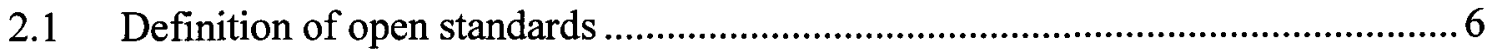

2.2 Standard development process and stakeholder analysis ............................... 11

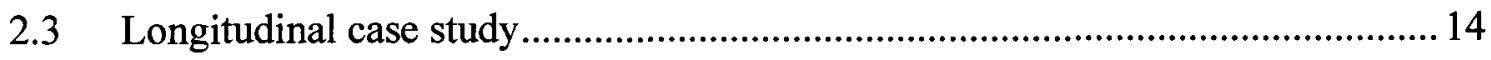

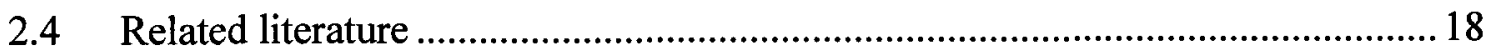

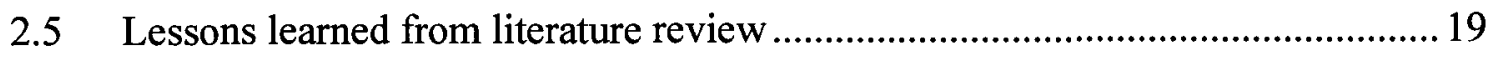

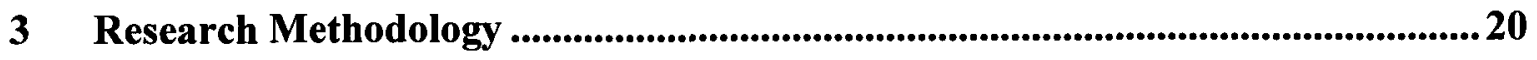

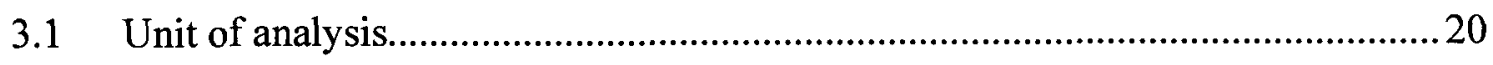

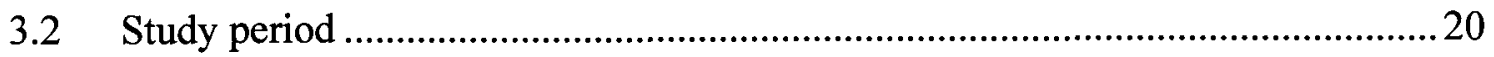

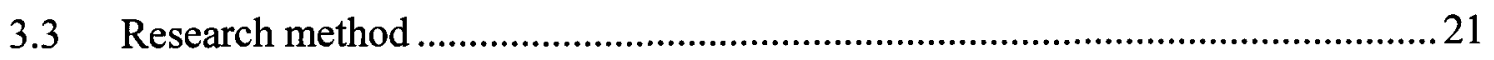

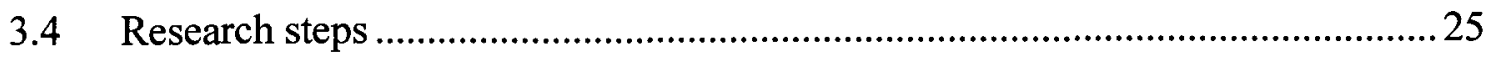

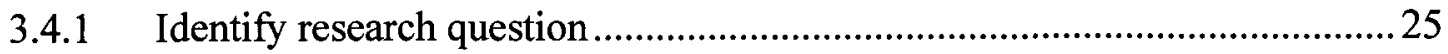




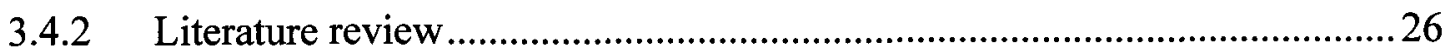

3.4.3 Research framework selection ...............................................................26

3.4.4 Data collection and preparation of the case study .......................................2

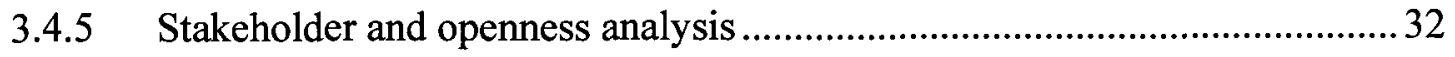

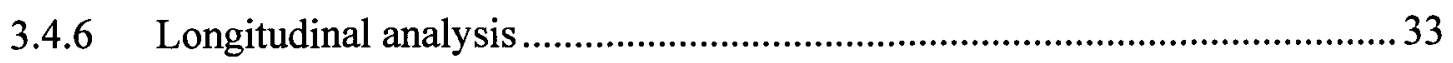

3.4.7 Identification of constructs ....................................................................... 38

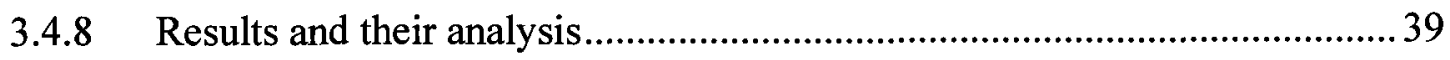

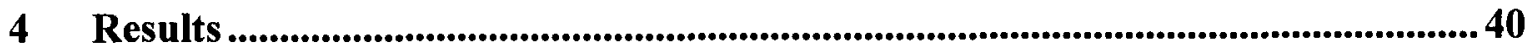

4.1 A brief description of the 3GPP LTE standard ...................................................40

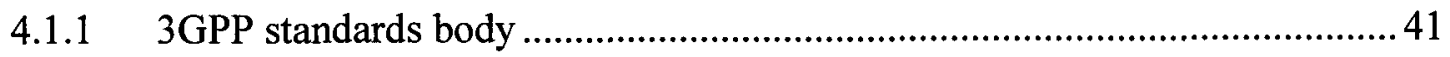

4.1.2 Next Generation Mobile Network (NGMN) alliance .................................... 41

4.1.3 LTE/SAE Trial Initiative (LSTI) .............................................................. 42

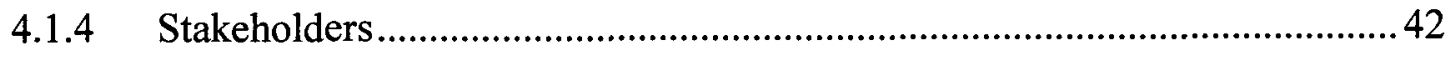

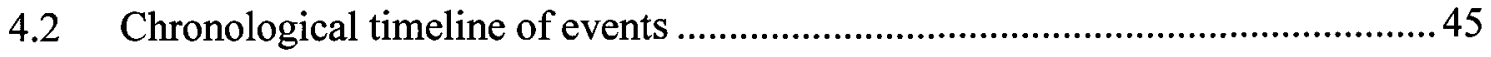

4.2.1 Chronological timeline of events in the 'NGMN activities' layer.................45

4.2.2 Chronological timeline of events in the stakeholders layer ...........................52

4.2.3 Chronological timeline of events in the 'LSTI activities' layer ....................67

4.2.4 Chronological timeline of events in the 'LTE standard release' layer ..........71

4.3 Analysis of cross layer linkage of events ............................................................ 75

4.4 Constructs to describe the convergence to the LTE .............................................8

$5 \quad$ Discussions of Results .......................................................................................................8

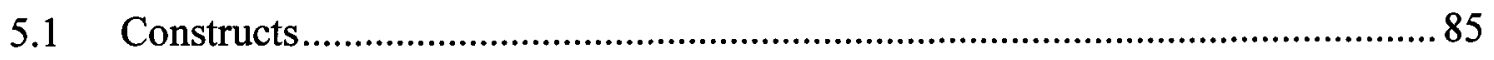

5.1.1 Common technology assets................................................................... 85 


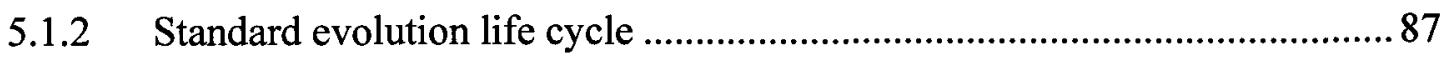

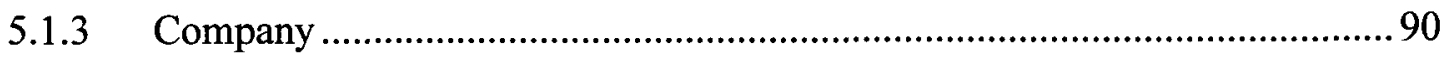

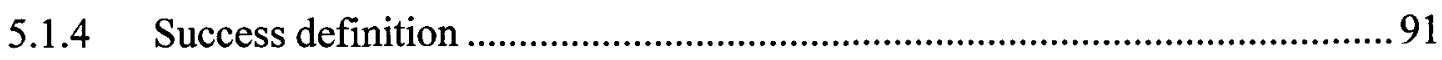

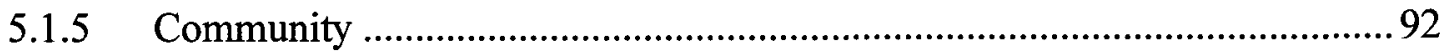

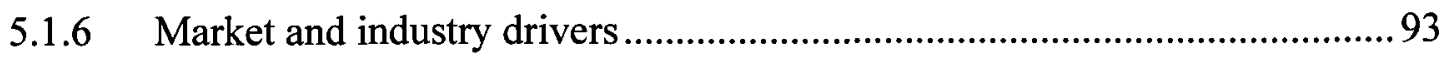

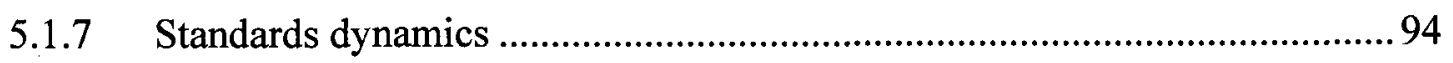

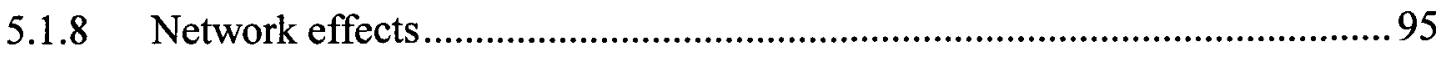

5.2 Comparison of identified construct to those identified by $\mathrm{Xu}(2007) \ldots \ldots \ldots \ldots \ldots . . . . . .96$

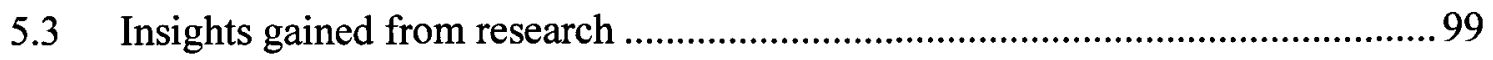

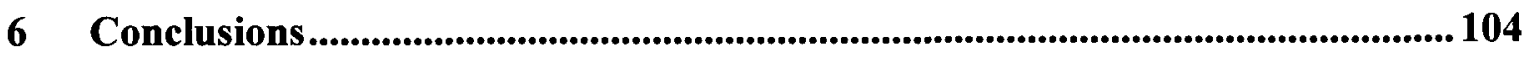

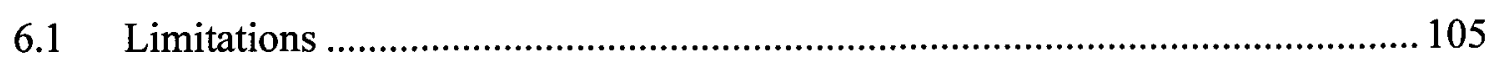

Suggestions for future research .......................................................... 106

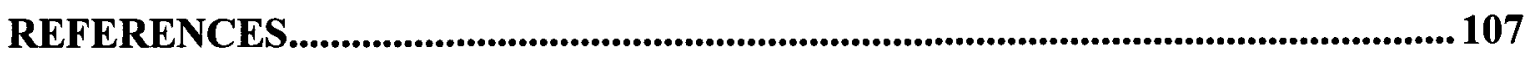

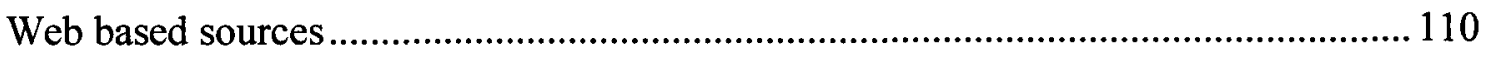

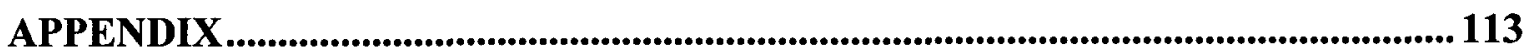

Appendix A: Case study of the 3GPP Long Term Evolution standard ..................... 113 


\section{List of Tables}

Table 2.1: Constructs describing the OpenAccess standard evolution ............................ 18

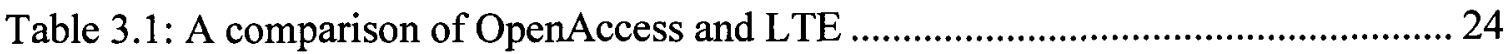

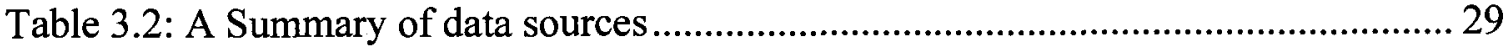

Table 3.3: List of Stakeholders included in case study ................................................ 29

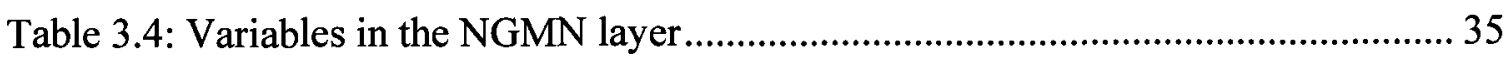

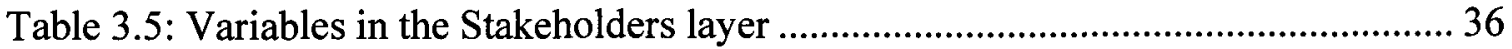

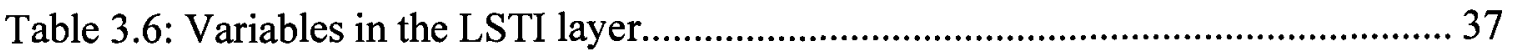

Table 3.7: Variables in the 3GPP LTE standard layer................................................ 37

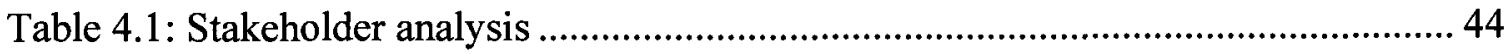

Table 4.2: Description of the events in the NGMN activities layer.............................. 46

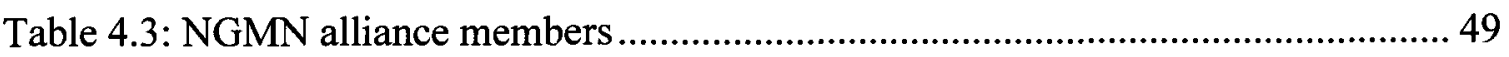

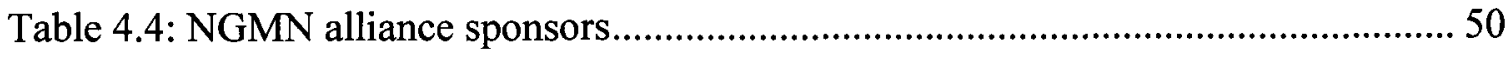

Table 4.5: Description of the events in the stakeholder: service provider layer............... 53

Table 4.6: Description of the events in the stakeholder: Network equipment vendors sub-

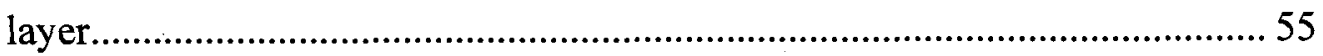

Table 4.7: Description of the events in the stakeholder: UE/chipset vendors sub-layer .. 56

Table 4.8: Service providers' commitment to LTE .......................................................58

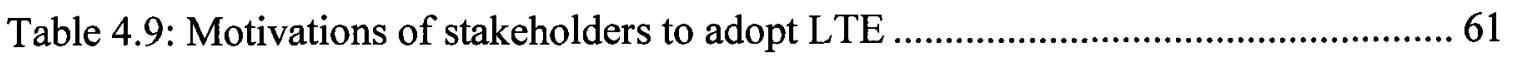

Table 4.10: Description of the events in the LSTI activities layer .................................67

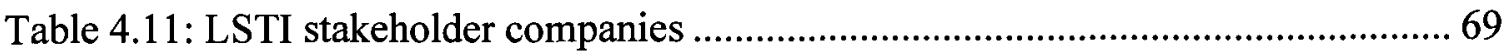

Table 4.12: Description of the events in the LTE standard release layer ....................... 71

Table 4.13: Openness analysis of LTE standard......................................................... 74

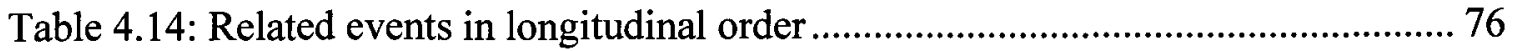

Table 4.15: Linkage among the events in various layers............................................. 79

Table 4.16: Constructs drawn from the LTE case study............................................ 81

Table 5.1: Comparison of constructs describing the LTE and OpenAccess................... 96 


\section{List of Figures}

Figure 4.1: Chronological timeline of events in the NGMN activities layer................... 45

Figure 4.2: Chronological timeline of events in the stakeholder: service provider sub-

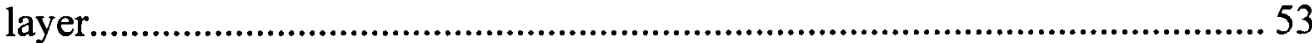

Figure 4.3: Chronological timeline of events in the stakeholder: Network equipment vendors sub-layer...

Figure 4.4: Chronological timeline of events in the stakeholder: UE/chipset vendors sublayer. 56

Figure 4.5: Chronological timeline of events in the LSTI activities layer.......................67

Figure 4.6: Chronological timeline of events in the LTE standard release layer ............ 71

Figure 4.7: Chronological timeline of all events in the 4 layers.................................... 75

Figure 4.8: Chronological timeline of related events................................................... 78

Figure 5.1: The pedigree of the LTE standard development ........................................ 86

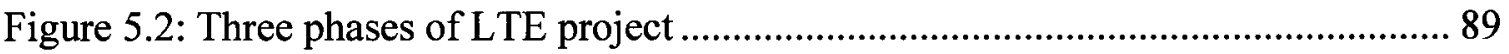




\section{Glossary of acronyms}

1xDO Rev0 - Data Optimized Revision 0 is an evolution of the CDMA IS-2000 standard and supports higher data rates of $2.4 \mathrm{Mbps}$ (downlink) and 153kbps (uplink).

1xDo RevA - Data Optimized Revision A is an enhancement of the 1xDO Rev0 standard and supports higher data rates of 3.1Mbps (downlink) and 1.8Mbps (uplink).

2G $-2 \mathrm{G}$ is short term for second generation mobile communication networks. These systems were the digital mobile communication systems introduced in the 1990's. GSM and CDMA are examples of $2 \mathrm{G}$ systems.

3G $-3 \mathrm{G}$ is short term for third generation mobile communication networks. These systems, introduced in the mid 2000 's, were created to handle demand for more data and higher bandwidth. UMTS and 1x DORev0/RevA are examples of 3G systems. 3GPP - Formed in 1998, the Third Generation Partnership Project fosters the development of $3 \mathrm{G}$ standards that descended from GSM.

3GPP-2 - Formed in 1998, the Third Generation Partnership Project 2 fosters the development of $3 \mathrm{G}$ standards that descended from CDMA. 4G $-4 \mathrm{G}$ is short term for fourth generation mobile communication networks, a system that will supersede the $3 \mathrm{G}$ systems. These systems are going to be all-IP networks providing very high throughput and innovative services. LTE, UMB and WiMAX are examples of $4 \mathrm{G}$ systems. 
ANSI - American National Standards Institute is a private non-profit organization that oversees the development of voluntary consensus standards for products, services, processes, systems, and personnel in the United States.

CAPEX - Capital expenditure are the expenditures towards purchase of new assets, technology or systems.

CDMA - Code Division Multiple Access is a radio access scheme used by IS-95 (aka cdmaOne) and IS-2000 (aka CDMA2000) standards.

De-facto standards - De-facto standard is a product or system that has achieved a dominant position by public/customer acceptance or market forces.

De-jure standards - De jure standards are those that emerge through industry consensus. This consensus may be informal, formally expressed through an industry standards body, or ratified by a standards organization.

EDA - Electronic Design Automation is the category of tools for designing and producing electronic systems ranging from printed circuit boards to integrated circuits. EDGE - Enhanced Data rates for GSM Evolution is an extension of GSM systems with higher data transmission rates.

ETSI - The European Telecommunications Standards Institute is the official European telecommunications standards organization recognized by the European Union. FDD - Frequency Division Duplexing refers to a transmission scheme that encompasses the transmitter and receiver operation at different carrier frequencies.

GSA - Global mobile Suppliers Association represents leading GSM/WCDMAHSPA/LTE suppliers worldwide. 
GSM - Global System for Mobile communication is a $2 \mathrm{G}$ digital mobile communication standard.

HSDPA - High Speed Downlink Packet Access is an enhanced 3G (also known as 3.5G or $3 \mathrm{G}+$ ) mobile communication standard for enhanced data rates for network to device transmission.

HSUPA - High Speed Uplink Packet Access is an enhanced 3G (also known as 3.5G or $3 \mathrm{G}+$ ) mobile communication standard for enhanced data rates for device to network transmission.

HSPA - High Speed Packet Access denotes a combination of HSUPA and HSDPA. HSPA+ - An evolution of HSPA with data rates enhancements.

IEEE - Institute of Electrical and Electronics Engineers is a non-profit professional association for the advancement of technology.

IETF - The Internet Engineering Task Force is a large open international community of network designers, operators, vendors, and researchers concerned with the evolution of the Internet architecture and the smooth operation of the Internet.

IPR - Intellectual Property Rights are a bundle of exclusive rights over creative work and give the copyright holder exclusive right to control reproduction or adaptation of such works for a certain period of time.

LSTI - LTE/SAE Trial Initiative is a global, collaborative technology trial initiative focused on accelerating the availability of commercial and interoperable LTE mobile broadband systems.

LTE - Long Term Evolution is a the $4^{\text {th }}$ generation mobile communication technology 
designed to increase the capacity and speed of mobile networks. LTE is standardized by $3 \mathrm{GPP}$ in its release 8.

NGMN - Next Generation Mobile Networks is an initiative by a world-wide group of leading mobile operators to provide a coherent vision for the mobile network technology evolution beyond $3 \mathrm{G}$ for the competitive delivery of mobile broadband wireless services. OPEX - Operational expenditure is the on-going cost for running a product or system. OSS - Open Source Software is a computer software for which the source code and certain other usage rights are provided under a software license to end user.

RAN - Radio Access Network is a component of the mobile communication network that sits between user equipment (handset) and core network. It encompasses a number of base transceiver stations.

SAE - System Architecture Evolution is the core network architecture of the LTE standard. SAE is simplified and based on an all-IP network. SAE can support mobility between radio access networks of legacy 3GPP standards. SAE also supports non-3GPP radio access networks as well.

SON - Self Organizing Networks is a set of requirements published in the form of use cases to enable automation in the operation of LTE radio access network. TDD - Time Division Duplex refers to a transmission scheme that encompasses an asymmetric transmitter and receiver operation at the same carrier but using different time slots.

UE - User Equipment is the term used for mobile terminals in LTE standard. UMB - Ultra Mobile Broadband was the project to define a 4G mobile communication standard by 3GPP2. The project was halted in November 2008 . 
UMTS - Universal Mobile Telecommunications System is the 3G mobile communication system developed by $3 \mathrm{GPP}$

W3C - The World Wide Web Consortium is an international consortium where member organizations, a full-time staff, and the public work together to develop Web standards. W3C's mission is to lead the World Wide Web to its full potential by developing protocols and guidelines that ensure long-term growth for the Web. WiMAX - Worldwide Interoperability Microwave Access is a IEEE packet radio access standard.

WCDMA - Wideband Code Division Multiple Access is a radio access scheme for the air interface in $3 \mathrm{G}$ mobile communication networks (e.g. UMTS) 


\section{Introduction}

The Long Term Evolution (LTE) standard is the evolutionary step towards achieving the Fourth Generation (4G) mobile communication systems. The Third Generation Partnership Project (3GPP) family of standards devised the foundation for this new standard. Some of the major benefits for this evolution are higher throughput and lower latency for data access. Lowering the cost per bit of traffic is another point in the value proposition of the standard. LTE enables a richer mobile service environment and provides for the efficient usage of limited available spectrum. A detailed case study of LTE is presented in Appendix A.

The majority of mobile communication service providers are operating the networks using two different families of standards: (i) 3GPP based (i.e. Global System for Mobile communication (GSM), Enhanced Data rates for GSM Evolution (EDGE), Universal Mobile Telecommunications System (UMTS), High Speed Downlink Packet Access (HSDPA), High Speed Packet Access (HSPA+)), and (ii) 3GPP-2 based (i.e. (Code Division Multiple Access (CDMA IS-95), CDMA IS-2000, 1x Data Only Revision 0 (1xDO Rev0), 1x Data Only Revision A (1xDO RevA)). Both families of standards were set to evolve to separate fourth generation technologies; the 3GPP family to LTE and the 3GPP-2 family to Ultra Mobile Broadband (UMB). In addition, a brand-new wireless 
communication standard, Institute of Electrical and Electronics Engineers (IEEE) 802$16 \mathrm{e}^{1}$ was proposed by IEEE in 2005.

Instead, the majority of the service providers has been participating in the development of LTE and have committed to adopting the LTE technology. With no adoption, work on UMB has been halted and mobile WiMAX has seen very little adoption by mobile communication service providers. Therefore, there is an ongoing convergence of mobile communication standards after many years of diverse standards deployed in various geographical locations (most of the North American networks are based on the 3GPP-2 standards and Europe has deployment of networks that are based on the 3GPP standards). This research describes the convergence process as the continuous commitment to the adoption of a single standard (i.e. LTE) by both, 3GPP based and non-3GPP based, service providers.

\subsection{Objectives}

The objective of this research is to answer the following research question and produce insights:

- What are the constructs that could be used to describe the convergence to the LTE mobile communication standard?

\footnotetext{
${ }^{1}$ IEEE $802-16 \mathrm{e}$ is popularly known as mobile Worldwide Interoperability Microwave Access (or WiMax)
} 


\subsection{Deliverables}

Deliverables of this research are:

- A visual representation of the longitudinal case study using context layers showing the timelines of key events describing the LTE evolution and acceptance

- A set of constructs describing the convergence to LTE with a comparison to constructs previously used to describe the OpenAccess standard (Xu, 2007)

- Insights generated from an analysis of the constructs developed to describe the convergence to LTE standard

\subsection{Relevance}

This research is relevant to at least three categories of individuals. One outcome of the research is the identification of additional areas of research and suggestions to extend the work. Therefore students and academic researchers will be interested in pursuing those areas of research. In addition, the longitudinal study in combination with stakeholder analysis is lacking a body of research literature.

Top management teams of new product and solution development firms will be interested in this research because it will provide them the insights about capturing value by being part of an open standardization process. They will learn the factors that affect the adoption of open standards, thereby allowing them to make better decisions to choose standards in relation to their product development strategies and, in doing so, they could 
become part of an emerging business ecosystem. Being part of an ecosystem, they could create value for and with customers and capture the value back for themselves.

Adopters and buyers of solutions can learn from this research because the adoption of open standards brings vendor independence, cost benefit, interoperability, seamlessness, scalability and reusability.

\subsection{Contributions}

This research makes contributions to the emerging literature on the convergence to open standards.

First, this research adopts a methodology enabling the development of insights about open standard convergence.

Second, it provides a set of constructs (with their constituent dimensions) that were found sufficient in describing the evolution of and the convergence to an emerging open standard.

Third, this research formulates research insights helping managers make better decisions in aligning their product development strategies with emerging open standards. 


\subsection{Organization}

The rest of this thesis is organized into five chapters. Chapter 2 provides the literature review and identifies the lessons learned from it. Chapter 3 describes the research method. Chapter 4 presents the results of the research. Chapter 5 discusses the results. Chapter 6 provides the conclusions, limitations, and suggestions for future research. 


\section{Literature review}

This chapter is organized into four sections. Section 2.1 reviews the literature on open standards. Section 2.2 reviews the literature on standard development process and stakeholder analysis. Section 2.3 examines the literature on longitudinal case study. Section 2.4 identifies the lessons learned from the literature review.

\subsection{Definition of open standards}

Standards represent a common agreement that enable communication, directly in the case of IT standards and indirectly in case of all other standards (Krechmer, 2006). Applying this definition of standards to the open standards makes their purpose to support communication in an open manner. There is no one complete definition of open standards and requirements that a standard must meet to qualify to be "open". Some definitions of open standards and associated principles as suggested in literature are compiled in this section.

The American National Standards Institute (ANSI) defines open standards as "A publicly available set of specifications describing the characteristics of a hardware device or software program. Open standards are published to encourage interoperability and thereby help popularize new technologies" (Arnold, 2005). Further, Arnold (2005) argues that open standards have the following properties:

- It is accessible and free of charge to all 
- It remains accessible and free of charge

- It is accessible free of charge and documented in all its details

The author of the open source definition, Bruce Perens ${ }^{2}$, presents six principles that make a standard open.

1. Availability - Open Standards are available for all to read and implement.

2. Maximize End-User Choice - Open Standards create a fair, competitive market for implementations of the standard. They do not lock the customer in to a particular vendor or group.

3. No Royalty - Open Standards are free for all to implement, with no royalty or fee. Certification of compliance by the standards organization may involve a fee.

4. No Discrimination - Open Standards and the organizations that administer them do not favor one implementer over another for any reason other than the technical standards compliance of a vendor's implementation. Certification organizations must provide a path for low and zero-cost implementations to be validated, but may also provide enhanced certification services.

5. Extension or Subset - Implementations of Open Standards may be extended, or offered in subset form. However, certification organizations may decline to certify subset implementations, and may place requirements upon extensions (see Predatory Practices).

\footnotetext{
${ }^{2}$ Open standards: principles and practices, http://perens.com/OpenStandards/Definition.html, last accessed
} Aug $9^{\text {th }} 2009$. 
6. Predatory Practices - Open Standards may employ license terms that protect against subversion of the standard by embrace-and-extend tactics. The licenses attached to the standard may require the publication of reference information for extensions, and a license for all others to create, distribute, and sell software that is compatible with the extensions. An Open Standard may not otherwise prohibit extensions.

Krechmer (2006) discusses the open standards requirements from the perspectives of creators, implementers and users of standards to depict what it means to them. Expectations of these stakeholders translate into ten requirements that enable open standards:

1. Open Meeting - all may participate in the standards development process.

2. Consensus - all interests are discussed and agreement found, no domination.

3. Due Process - balloting and an appeals process may be used to find resolution.

4. Open IPR - how holders of IPR related to the standard make available their IPR.

5. One World - same standard for the same capability, world-wide.

6. Open Change - all changes are presented and agreed to in a forum supporting the five requirements above.

7. Open Documents - committee drafts and completed standards documents are easily available for implementation and use.

8. Open Interface - supports proprietary advantage (implementation); each interface is not hidden or controlled (implementation); each interface of the implementation supports migration (use). 
9. Open Access - objective conformance mechanisms for implementation testing and user evaluation.

10. On-going Support - standards are supported until user interest ceases rather than when implementer interest declines.

Krechmer (2006) also maps these open standards requirements to the six open standards principles proposed by Perens. He suggests that the six principles proposed by Perens map fully into eight of the ten requirements of open standards. Perens does not directly address in the six principles the desire for or against One World or the end user requirements of on-going support.

Krechmer (2006) suggests that an implementer of an existing standard would call the standard open when it serves the market they wish, it is without cost to them, does not preclude further innovation (by them), does not obsolete their prior implementations, and does not favor a competitor. He describes that the user of an implementation of the standard would call a standard open when multiple implementations of the standard from different sources are available, when the implementation functions in all locations needed, when the implementation is supported over the user-planned service life, and when new implementations desired by the user are backward compatible to previously purchased implementations. 
The US Department of Defense defines ${ }^{3}$ open standards as "Standards that are widely used, consensus based, published and maintained by recognized industry standards organizations".

Tiemann (2006) discusses the benefits of open standards and proposes four distinguishing levels of open standards:

- Open Standard 0: The standard is documented and can be completely implemented, used, and distributed royalty free (just as the World Wide Web Consortium (W3C) requires of any standards submitted to them). Implementations of the standard may be extended, or offered in subset form. However, certification organizations may decline to certify subset implementations, and may require that extensions also satisfy the criteria of an Open Standard. Anything less than this is not an Open Standard, period.

- Open Standard 1: There is specified Open Source Software (OSS) that can interoperate with the standard. Moreover, if there is an interoperability issue between a product claiming Open Standard 1 and the specified OSS product, it means that the vendor of the Open Standard 1 product will be responsive to interoperability questions or issues raised by developers of the specified OSS product.

- Open Standard 2: There is an OSS reference implementation of the standard.

\footnotetext{
${ }^{3}$ Open systems defined, terms \& definitions, http://www.acq.osd.mil/osjtf/termsdef.html, last accessed Aug $9^{\text {th }} 2009$.
} 
- Open Standard 3: This implementation of the standard is an OSS implementation.

West (2007) examines the economical perspective of standards and argues against the simplified view that there is a single model of an open standard, as well as the assumption that a fully open solution is always an optimal (or even a feasible) outcome. Existing research literature focuses chiefly on the specification of the standards and overlook the technology convergence. Although showing recent signs of advancement, the literature of standard convergence still seems fragmented. Most of the academic literature on standards is concerned with the economic analysis of network externalities and compatibility, the role of standards as tools of competitive strategy, and the determinants of the use and supply of standards (Bailetti \& Callahan, 1995). A major reason is the lack of a consistent framework to unify various factors that may affect standard convergence.

\subsection{Standard development process and stakeholder analysis}

Knowledge of the standards development process and motivation of the stakeholders in that process is very important in this research. Dargan (2005) specifies that open system standards are defined by formal standards bodies and vendor consortia. There are standards bodies that operate at a national level and there are standards bodies that operate at the international level. Dargan (2005) specifies that IEEE, ANSI and Internet Engineering Taskforce (IETF) have been designated as formal standards setting bodies in the United States. European Telecommunications Standards Institute (ETSI) is a 
telecommunication standards body that operates at the European level. Dargan (2005) further defines the vendor consortia as organizations primarily composed of companies from industry that have a vested interest in defining standards for their own commercial products and who work together to achieve consensus on standard services and interfaces. Bailetti \& Callahan (1995) argue that a standards strategy is a plan to achieve consistency between product development and public standards evolution. The focus of the plan is the alignment of the purpose of the firm's participation in standards development, the identification of the activities to be undertaken, and the structure required to implement these activities.

The IEEE standards training website ${ }^{4}$ describes a simplified version of their standards process:

- Idea: The idea for a standard is usually developed by a group of people, and the responsibility for the idea is assumed by the sponsor. The sponsor is usually a society or an existing standards committee.

- Project Approval Process: This idea is then transferred onto a form called the Project Authorization Request (PAR) and submitted to the New Standards Committee (NesCom) for approval. A working group is formed that owns the development of standard.

\footnotetext{
${ }^{4}$ Overview of the standards process, http://standards.ieee.org/faqs/train-list.html\#Overview, last accessed on Aug $9^{\text {th }} 2009$.
} 
- Develop draft standard: The draft is then developed and revised by the working group.

- Ballot draft: When the draft work is finalized, the sponsor forms the balloting group and ballots the standard.

- Standards Board Approval: After a ballot has achieved consensus, the draft then goes to the Review Committee (RevCom) and the Standards Board for approval. The amount of time from PAR to Board approval is at most 4 years (an extension can be made if absolutely necessary).

- Publish Standard: The draft is then edited and formatted by an IEEE Project Editor and published.

- The standard is valid for 5 years before it must be reaffirmed, revised, or withdrawn.

Dargan (2005) describes the vendor consortia standards definition process. This process is very similar to the formal process followed by standards bodies. Further, the author lists information like inception date, purpose, history, membership details of various standards bodies and vendor consortia.

Kazi (2006) argues that member organizations are motivated to come together to reach common objectives in order to create and develop new markets whose evolution depends on the interoperability of the systems produced by different vendors and the interconnection of the networks of different operators. It is the drive of this common goal to move technology forward and create demand for the products or services in the 
market. Choi et al. (2004) assert that the participants in a standards body may have divergent goals and may exhibit strategic behaviour. Each participant in standards bodies behaves in 'goal-directed' ways to achieve its own goal(s). Participants in standards bodies prefer a standard to no standard, but each prefers its own standards to the alternative.

The analysis of stakeholder identification, interdependence, relevance and positioning is a component of this research. De Vries et al. (2003) present a method for stakeholder identification and classification that can be applied to information technology standardization processes. The authors suggest using nine different search dimensions for the identification of stakeholders: production chain, end users and related organizations, designers, value chain members associated with the development of the physical system, inspection agencies, regulators, researchers \& consultants, educators and other representative organizations. Their approach to the consequent analysis includes stakeholders' positioning along three dimensions: power $(\mathrm{P})$, legitimacy $(\mathrm{L})$ and urgency (U). This provides eight possible types of stakeholders based on the combinations of $\mathrm{P}, \mathrm{L}$ and $\mathrm{U}$ : dormant $(\mathrm{P})$, discretionary $(\mathrm{L})$, demanding $(\mathrm{U})$, dominant $(\mathrm{P}, \mathrm{L})$, dangerous $(\mathrm{P}, \mathrm{U})$, dependent $(\mathrm{L}, \mathrm{U})$, definitive $(\mathrm{P}, \mathrm{L}, \mathrm{U})$ and non-stakeholders.

\subsection{Longitudinal case study}

The case study is a research strategy which focuses on understanding the dynamics present within single settings (Eisenhardt, 1989). Yin (2003) suggests that a case study is 
an empirical enquiry that investigates a contemporary phenomenon within its real-life context, especially when the boundaries between phenomenon and context are not clearly evident and it relies on multiple sources of evidence. This strategy is ideally utilized when a rounded and detailed investigation is necessary.

Yin (2003) describes that there can be single-case or multiple-case applications in exploratory, explanatory, and descriptive types of case studies. Selecting between multiple or single cases is a critically important choice (Yin, 2003; Eisenhardt \& Graebner, 2007). A single-case study may be used to confirm or challenge a theory, or to represent a unique or extreme case. It is also ideal for revelatory cases where an observer may have access to a phenomenon that was previously inaccessible (Yin, 2003).

Siggelkow (2007) argues that if a single-case study methodology is used, the research cannot just focus on description, but also has to provide conceptual insight. Siggelkow (2007) suggests that there are at least three important uses for single-case studies: to motivate a research question, to inspire emerging theory, and to be employed as illustration.

Eisenhardt \& Graebner (2007) describe that the case studies is a research strategy that involves using one or more cases to create theoretical constructs. A key strength of the case study method involves consideration of construct validity, internal validity, external validity, and reliability (Yin, 2003). The author further suggests using multiple sources of evidence as the way to ensure construct validity. Typically, case-study-based research 
uses multiple sources of evidence such as ethnographic observation, in-depth interviews (in particular, oral histories), and historical documents. The specification of the unit of analysis is important for the internal validity as the theories are developed and data collection and analysis are used to test those theories. Both qualitative and quantitative research methods may be used (Yin, 2003). External validity is more difficult to attain in a single-case study. Yin (2003) suggests that external validity could be achieved from theoretical relationships on which generalizations could be made.

Pettigrew (1990) describes that the theoretically sound and practically useful research on change should explore the contexts, content, and process of change together with their interconnections through time. Pettigrew (1990) suggests a form of research which is contextualist and processual in character. A contextualist analysis of a process such as change draws on phenomena at vertical and horizontal levels of analysis and the interconnections between those levels through time. The vertical level refers to the interdependencies between higher or lower levels of analysis of the phenomena. The horizontal level refers to the sequential interconnectedness among phenomena in historical, present, and future time (Pettigrew, 1990).

Although dynamism has been difficult to study, the cross-sectional analysis of sequential static states leads to an understanding of the dynamics of change across time and space (Pettigrew, 1990). To describe the process of change through the evolution of states of events, it is quite common that process is encapsulated in the form of variables. Van de Ven \& Poole (1995) argue that, in the literature on change, the process should refer to a 
sequence of events that describe how things change over time. At the most general level, questions such as what, who, where, when, why, and how are the special features of a process that can help uncover novel theoretical questions and reveal original findings (Pettigrew et al., 2001). Temporal history needs to be understood as events, chronology, structures, and underlying logic (Pettigrew et al., 2001).

Pettigrew (1990) emphasizes three key points in analyzing change in a multi-level, longitudinal contextual research: (i) change should be studied within the context of changes happening at other levels of analysis, (ii) the temporal interconnectedness is very important and is noticeable by locating change in past, present and future time, and (iii) the context and action should be explored, context is a product of action and vice versa.

The research outcome from a longitudinal single-case study may be in one of the following forms: (i) a case as an analytical chronology which tells the story across different levels of analysis, (ii) a diagnostic case which contains the features of an analytical chronology but, in addition, contains a listing and analysis of the organization's current strategic concerns, and (iii) an interpretative/theoretical case which interprets the narrative and links emerging conceptual and theoretical ideas inductively derived from the case both to stronger analytical themes within the case and wider theoretical debates in the literature (Pettigrew, 1990). Siggelkow (2007) argues that the ability to get closer to theoretical constructs is particularly important in the context of longitudinal research that tries to unravel the underlying dynamics of phenomena that play out over time. 


\subsection{Related literature}

A similar study was done by $\mathrm{Xu}(2007)$ to examine the constructs and their constituent dimensions describing the evolution of OpenAccess standard. Chapter 3 describes the similarities in the research methodology between Xu (2007) and this research. Xu (2007) utilizes a multi-level longitudinal case study of the OpenAccess standard to determine the constructs and their constituent dimensions describing the evolution of the standard.

Table 2.1 lists the constructs and their constituent dimensions identified by $\mathrm{Xu}$ (2007).

Table 2.1: Constructs describing the OpenAccess standard evolution

\begin{tabular}{|l|l|}
\hline Construct & Dimension \\
\hline Common asset & Pedigree \\
\cline { 2 - 2 } & Rights \\
\hline Project life cycle & Phase \\
\hline Community & Goals \\
\cline { 2 - 2 } & Member structure \\
\cline { 2 - 2 } & Veto power \\
\cline { 2 - 2 } & Contribution records \\
\cline { 2 - 3 } & User composition and growth \\
\cline { 2 - 2 } & IT support \\
\hline Company & Proprietary asset release \\
\cline { 2 - 3 } & Market offers \\
\cline { 2 - 3 } & Internal use \\
\cline { 2 - 2 } & Direct competition \\
\cline { 2 - 3 } & Standard adoption \\
\hline Success definition & Standard acceptance \\
\cline { 2 - 3 } & Number of OAC members \\
\cline { 2 - 2 } & Top EDA company participation \\
\hline
\end{tabular}




\subsection{Lessons learned from literature review}

There are several lessons learned from the literature review. Following are the key lessons learned:

- There are no single well defined classifications that could be used to evaluate the openness of standards (Krechmar, 2006; Tiemann, 2006; West2007)

- There is little body of literature on dynamics of evolution of emerging standards

- Standards compete for adopters in a way similar to innovations and new technologies (Hovav et al., 2004)

- There is little known about the relationship between level of openness and the adoption of emerging technology systems

- The existing literature does not seem to take into account the impact of the ongoing technology convergence processes in the industry on the adoption of emerging open standards 


\section{Research Methodology}

This chapter is divided into four main sections. Section 3.1 identifies the unit of analysis, Section 3.2 outlines the study period, Section 3.3 stipulates a brief summary of the research method, Section 3.4 identifies the steps involved in this research and Sections 3.4.1 to 3.4.8 provide a brief description of each of the research steps.

\subsection{Unit of analysis}

The unit of analysis is the process of technological convergence towards the 3GPP LTE mobile communication standard.

\subsection{Study period}

The study period is from the fourth quarter of 2004 to the second quarter of 2009. The fourth quarter of 2004 was selected as the starting point in time for the data collection because in November 2004, the 3GPP began the project defining the long term evolution of the GSM/UMTS family of mobile communication technology. In June 2009 the data collection was completed, i.e. June 2009 was identified as the final point in time of the case study. The majority of the case study data is from 2006 onwards, as this was the time when synergy among the service providers and the vendor community started and a collaboration period emerged in an effort to define the LTE technology and its evolution. 


\subsection{Research method}

The research utilizes a multi-level longitudinal case study method to explore the context, process and content of change associated with all relevant events and stakeholders involved in the convergence of the majority of mobile communication standards to the LTE standard.

Studying the process of large scale technology convergence to a single standard poses significant methodological challenges. The process is a complex unit of analysis incorporating activities across multiple levels, multiple industrial contexts and multiple stakeholders. The choice of a single-case study approach was driven by several factors. First, this is due to the radical nature of the convergence to the LTE mobile communication standard where multiple families of standards are converging primarily to a single standard. The technological convergence is radical in nature, scope, degree and speed and this is what makes it a unique phenomenon appropriate for a single-case study approach (Siggelkow, 2007). Second, this is due to the coincidence between the study period and the period of the most radical convergence - by the end of the study period important events were literally happening every week. This coincidence provided the unique opportunity to apply the longitudinal case study method during the times of important change and not post-factum, as it is usually the case. This opportunity enables the formulation of new research insights that are relevant in a dynamically changing context. The inspiration for the formulation of such new research insights was a key motivation for using a single-case study (Siggelkow, 2007) since there is very little knowledge about the nature and the dynamics of technological convergence in mobile 
communication standards. The third reason to choose a single-case study approach was the need for in-depth archival and key informants' data on the context and content of the events as well as the degree of researcher's involvement in the process and access to the data.

The method was designed as an inductive research approach (Christensen \& Raynor, 2003). Public source data describing the actions of various stakeholders (mainly service providers and vendors) around requirement settings, alliance forming, standard development and adoption were collected and an explanatory narrative story was developed following a chronological pattern of presentation. All the collected data was categorized into four main layers following the logic derived from the longitudinal field research method described by Pettigrew (1990). Graphical representations of all relevant events and actions were visually organized for each of the layers. The relationships between events in different layers were identified and preliminary insights were formulated. The initial research phase resulted in a descriptive case containing all of the features of an analytical chronology, a graphical representation and an analysis of links between events along the four different layers and a summary of preliminary insights of relevance for both academics and executive managers. The preliminary formulated insights were then refined and finalized.

The method described above was designed in a way that allowed using all possible insights from a similar approach employed by Xu (2007) to examine the constituent dimensions of constructs describing the evolution of the OpenAccess standard. However, 
there are some key differences between LTE and OpenAccess. First, there is a difference in the scope of the standardization process. Although the need for the OpenAccess standard emerged within the context of clearly defined multiple stakeholders, the initial stage of its evolution was driven by one main stakeholder type - the Electronics Design Automation (EDA) companies. This is different from the case of LTE where the rationale for the evolution is driven by a much broader technological context, by multiple stakeholders across multiple industries. It is therefore necessary to develop the longitudinal analysis by incorporating a detailed identification of all relevant stakeholders (De Vries et al., 2003) involving an analysis of their motivations, concerns, risks and benefits. Second, there is a difference in the nature of the technology which affects the nature of standard openness and the corresponding evolution processes. The technological evolution of the OpenAccess standard was enabled by a private company technology donation and was based on a "quasi" open source reference implementation driven by the governance body - the OpenAccess coalition and the Silicon Integration Initiative. The LTE technology evolution was driven by the formulation of industry-wide requirements by the Next Generation Mobile Networks (NGMN) alliance and supported by the technology contribution, coordination and implementation mechanisms of the LTE/System Architecture Evolution (SAE) Trial Initiative (LSTI). Its level of openness was not defined based on the terms of access to a reference implementation (there was no such implementation at all) but on a set of principles that were set up from the very beginning of the standardization process. This is why the LTE evolution could be better studied and analyzed in terms of technology convergence. A third key difference is found in the degree and speed of the evolution processes. The OpenAccess evolution was driven 
by the logic of technology adoption following the major characteristics of the adoption life cycle (Rogers, 2003; Moore, 2000). The evolution of LTE was driven by the logic of technology convergence including strong network effects, i.e. it was radical in degree and speed. This last difference was another major motivation for applying a methodology similar to the one employed by $\mathrm{Xu}(2007)$ - the LTE case was found to be appropriate for its validation within a broader research context. A comparison of the key differences between the OpenAccess and LTE standards context is depicted in Table 3.1.

Table 3.1: A comparison of OpenAccess and LTE

\begin{tabular}{|l|l|}
\hline \multicolumn{1}{|c|}{ OpenAccess } & \multicolumn{1}{|c|}{ LTE } \\
\hline Relevant to a narrower industrial context & Relevant to multiple industries \\
\hline Analysis of one major stakeholder & $\begin{array}{l}\text { Necessitating the analysis of multiple } \\
\text { stakeholders }\end{array}$ \\
\hline $\begin{array}{l}\text { Technology evolution driven by an initial } \\
\text { free release of private technological assets }\end{array}$ & $\begin{array}{l}\text { No standard technology available at the } \\
\text { beginning, i.e. evolution driven by complex } \\
\text { technology contribution, coordination and } \\
\text { implementation mechanisms }\end{array}$ \\
\hline $\begin{array}{l}\text { Dynamics - incremental adoption driven by } \\
\text { the logic of technology adoption life cycle }\end{array}$ & $\begin{array}{l}\text { Dynamics - a high degree of (radical) } \\
\text { acceptance within a very short period of } \\
\text { time driven by the logic of technology } \\
\text { convergence and network effects }\end{array}$ \\
\hline
\end{tabular}




\subsection{Research steps}

The research proceeded according to the following steps:

- Formulate research question

- Study literature and formulate lessons learned

- Devise the research framework

- Collect data and prepare case study

- Perform stakeholder and openness analysis

- Specify the steps of the longitudinal analysis

- identify layers and organize chronological timeline of events for each layer

- identify the variables both global and by layer

○ identify the linkages between events and variables

- Identify the constituent dimensions of the constructs describing the technology convergence process

- Provide summary of results and their analysis

- Formulate research insights

- Make conclusions

\subsubsection{Identify research question}

The following research question was identified:

- What are the constructs that could be used to describe the convergence to the LTE mobile communication standard? 


\subsubsection{Literature review}

Research involved the review of literature in three major research streams: open standards (Krechmar, 2006; Tiemann, 2006; West2007), stakeholder identification theory and standards development (De Vries et al., 2003; Bailetti \& Callahan, 1995; Dargan, 2005; Kazi, 2006), and longitudinal case study (Eisenhardt, 1989; Siggelkow, 2007; Pettigrew, 1990; Pettigrew et al., 2001; Xu, 2007). Literature on the working of 3GPP was also reviewed using white papers, books and industry reports.

\subsubsection{Research framework selection}

The selection of the specific research framework was critical to appropriately understand and describe the phenomenon of technological convergence to a single mobile communication standard. As the events were still ongoing as the research was conducted, a case study involving analysis of events and actions taken by various stakeholders was deemed appropriate. The insights provided by Pettigrew (1990) were used in devising the key steps in conducting the longitudinal case study based research method. The technology convergence phenomenon involved various stakeholders (e.g. service providers, vendors etc). The longitudinal research method was therefore augmented by a stakeholder identification analysis (De Vries et al., 2003). The degree and nature of standard openness was expected to play a key role in describing the convergence to a single standard. The analysis of LTE openness was conducted based on the analytical 
approach suggested by Krechmer (2006). The details of the research framework are described in Section 3.3.

\subsubsection{Data collection and preparation of the case study}

3GPP is the standard setting body for the LTE mobile communication standard. 3GPP maintains the documentation on the LTE standard and contributions by individual member organization. The 3GPP website provides this documentation freely. The $3 \mathrm{GPP}$ website was one of the main data sources for this research. 3GPP working procedures, internal press releases, archived webinars, stakeholders' news and external press releases were reviewed.

The NGMN alliance website was the source of very helpful material for the case study. NGMN is an alliance among mobile communication service providers to prepare requirements for their next generation networks. These requirements were contributed into standards bodies including 3GPP. NGMN "white papers" on the requirements and news releases were reviewed for the case study.

LSTI is an initiative among service providers and vendors and its mandate is to perform proof-of-concept and interoperability trials of the LTE mobile communication technology. Results from the field trials were fed back into the standard development process to fine-tune the standard so that the final standard is complete. Another reason for the trials was to make sure the technology is ready to be deployed right after the first 
release of the standard. LSTI activities were of the utmost importance for this case study as these activates were a result of collaboration among service providers, various vendors and standards body. Trial results and news releases were reviewed for the research.

LTE-related announcements and press releases from various types of stakeholders were of prime importance. These actions by stakeholders (individually and as part of alliances) helped to formulate a chronological orders of events, required for longitudinal case study research.

Additionally, the Google search engine was utilized to search various industry news papers, magazines and blogs. The search was using stakeholders' names (See Table 3.3 for a list of various types of stakeholders) along with keywords "LTE" and/or "SAE". Table 3.2 summarizes the major data sources for the case study. 
Table 3.2: A Summary of data sources

\begin{tabular}{|c|c|c|}
\hline Data Source & $\begin{array}{l}\text { Period } \\
\text { Covered }\end{array}$ & Description \\
\hline $3 \mathrm{GPP}$ & $\begin{array}{l}\text { Nov. } 2004- \\
\text { Jun. } 2009\end{array}$ & $\begin{array}{l}\text { Internal and external press releases of } 3 \mathrm{GPP} \text { and associated } \\
\text { stakeholders are regularly published on website (www.3gpp.org). } \\
\text { Working procedures and organization structure of } 3 \mathrm{GPP} \text { were also } \\
\text { studied. }\end{array}$ \\
\hline NGMN & $\begin{array}{l}\text { Sep. } 2006- \\
\text { Jun. } 2009\end{array}$ & $\begin{array}{l}\text { Mandate of NGMN, requirement white papers and work program } \\
\text { structure were reviewed from website (www.ngmn.org). Regular } \\
\text { press releases were taken into consideration as well. }\end{array}$ \\
\hline LSTI & $\begin{array}{l}\text { Jan. } 2007- \\
\text { Jun. } 2009\end{array}$ & $\begin{array}{l}\text { Objectives of LSTI and its organizational structure was reviewed from } \\
\text { website (www.lstiforum.org). Regular press releases were taken into } \\
\text { consideration as well. }\end{array}$ \\
\hline $\begin{array}{l}\text { Stakeholder } \\
\text { actions and } \\
\text { press releases }\end{array}$ & $\begin{array}{l}\text { Sep. } 2006- \\
\text { Jun. } 2009\end{array}$ & $\begin{array}{l}\text { LTE technology solutions and press releases from various } \\
\text { stakeholders were reviewed. }\end{array}$ \\
\hline $\begin{array}{l}\text { Major industry } \\
\text { news websites }\end{array}$ & $\begin{array}{l}\text { Nov. } 2004- \\
\text { Jun. } 2009\end{array}$ & $\begin{array}{l}\text { Major trade magazines and news website were searched for LTE } \\
\text { related news items. Major sites include unstrung.com, } \\
\text { telecommagazine.com and lightreading.com. }\end{array}$ \\
\hline
\end{tabular}

Table 3.3: List of Stakeholders included in case study

\begin{tabular}{|l|l|c|}
\hline Stakeholders name & Stakeholder type & Stakeholder website \\
\hline Bell Mobility & Service Provider & www.bellmobilty.ca \\
\hline
\end{tabular}




\begin{tabular}{|c|c|c|}
\hline Telus Mobility & Service Provider & www.telusmobility.com \\
\hline Rogers Wireless & Service Provider & www.rogers.com \\
\hline Verizon & & \\
\hline Communications & Service Provider & www.verizon.com \\
\hline AT\&T & Service Provider & www.att.com \\
\hline Alltel & Service Provider & www.alltel.com \\
\hline Sprint & Service Provider & www.sprint.com \\
\hline t-mobile US & Service Provider & www.t-mobile.com \\
\hline Vodafone & Service Provider & www.vodafone.com \\
\hline t-mobile international & Service Provider & www.t-mobile.com \\
\hline Telia Sonera & Service Provider & www.teliasonera.com \\
\hline KDDI & Service Provider & www.kddi.com/english/ \\
\hline NTT DoCoMo & Service Provider & www.nttdocomo.com \\
\hline SK-Telcom & Service Provider & www.sktelecom.com \\
\hline $\begin{array}{l}\text { Nokia Siemens } \\
\text { Networks }\end{array}$ & $\begin{array}{l}\text { Telecom Equipment } \\
\text { Vendor }\end{array}$ & www.nokiasiemensnetworks.com \\
\hline Ericsson & $\begin{array}{l}\text { Telecom Equipment } \\
\text { Vendor }\end{array}$ & www.ericsson.com \\
\hline Alcatel-Lucent & $\begin{array}{l}\text { Telecom Equipment } \\
\text { Vendor }\end{array}$ & www.alcatel-lucent.com \\
\hline Nortel & $\begin{array}{l}\text { Telecom Equipment } \\
\text { Vendor }\end{array}$ & www.nortel.com \\
\hline Hitachi & Telecom Equipment & www.hitachi.com/products/it/network/index.html \\
\hline
\end{tabular}




\begin{tabular}{|c|c|c|}
\hline & Vendor & \\
\hline Huawei & $\begin{array}{l}\text { Telecom Equipment } \\
\text { Vendor }\end{array}$ & www.huawei.com \\
\hline ZTE & $\begin{array}{l}\text { Telecom Equipment } \\
\text { Vendor }\end{array}$ & www.zte.com.cn/en/ \\
\hline Starent Networks & $\begin{array}{l}\text { Telecom Equipment } \\
\text { Vendor }\end{array}$ & www.starentnetworks.com \\
\hline NEC & $\begin{array}{l}\text { Telecom Equipment } \\
\text { Vendor }\end{array}$ & www.nec.com/global/solutions/nsp/ \\
\hline Motorola & $\begin{array}{l}\text { Telecom Equipment } \\
\text { Vendor }\end{array}$ & www.motorola.com \\
\hline Nokia & UE Vendor & www.nokia.com \\
\hline RIM & UE Vendor & www.rim.com \\
\hline LG & UE Vendor & www.lge.com \\
\hline Apple & UE Vendor & www.apple.com \\
\hline Sony Ericsson & UE Vendor & www.sonyericsson.com \\
\hline Samsung & UE Vendor & www.samsung.com \\
\hline Qualcomm & Chipset Vendor & www.qualcomm.com \\
\hline NXP Semiconductors & Chipset Vendor & www.nxp.com \\
\hline ST-Ericsson & Chipset Vendor & www.stericsson.com \\
\hline Anritsu & $\begin{array}{l}\text { Test Equipment } \\
\text { Vendor }\end{array}$ & www.anritsu.com \\
\hline Agilent & $\begin{array}{l}\text { Test Equipment } \\
\text { Vendor }\end{array}$ & www.agilent.com \\
\hline
\end{tabular}




\begin{tabular}{|l|l|c|}
\hline Rohde \& Schwarz & Test Equipment & www.rohde-schwarz.com \\
\hline Tektronix & Test Equipment & www.tek.com \\
\hline
\end{tabular}

Using the collected data, a descriptive single-case study of the LTE project was written. The case study is provided in Appendix A.

\subsubsection{Stakeholder and openness analysis}

The research methodology required an analysis of the stakeholders and their motivations to provide products and services based on LTE. Stakeholder analysis was performed based on the stakeholder identification process suggested by De Vries et al. (2003). An additional analysis of stakeholders' motivations was conducted to determine emerging patterns in their motivations to converge to the LTE standard.

Convergence to a newly emerging standard (i.e. not a de-facto standard) cannot be discussed without a discussion of the nature of its openness. The LTE standard openness analysis was based on standard openness literature (Tiemann, 2006; Krechmer, 2006; West, 2007). Xu (2007) applied Tiemann's approach to determine the OpenAccess standard openness. The LTE standard was evaluated against level of openness principles suggested by Tiemann (2006) and it was found that the LTE standard requires a different perspective that was better addressed by the criteria for standards openness suggested by 
Krechmer (2006). Insights from West (2007) were also used to gain some additional insights.

\subsubsection{Longitudinal analysis}

Longitudinal analysis was carried out based on the method for conducting longitudinal research on change articulated by Pettigrew (1990). Analysis involved the following steps:

- Identify context, process and content layers and prepare a chronological timeline of events associated with each layer by taking into account all relevant stakeholders

- Identify variables describing the dynamics of change within and across layers from perspectives involving all identified stakeholders

- Identify the linkages between events and variables within and across layers.

\section{Identification of layers}

The case study presented in Appendix A was used as the data repository for the research. The longitudinal research on change methodology suggests using multiple contextual layers of events to study the chronological dynamics of change. The events identified in the case study were organized into four layers: 1) Events associated with NGMN activities, 2) Events associated with stakeholders activities (covering service providers, network equipment vendors and User Equipment (UE)/Chipset vendors), 3) Events associated with LSTI activities, and 4) Events related to LTE standard specification 
releases. Events in each layer were presented in a chronological sequence. The identification of the layers was driven by the need to describe a) context (layer $1 \& 2$ ), b) process (layer 3), and c) content (layer 4). The research captured the events in all layers that were relevant to the studied phenomenon of convergence.

Layer 1 (NGMN activities) involves the events occurring in the NGMN alliance that provides a view of the service provider community in terms of their requirements for the next generation mobile communication networks. Layer 2 (Stakeholders) provides the actions of all relevant stakeholders driven by their economical, technological and business motivations for joining or resisting joining the convergence to LTE in association with their specific product development strategies. These two layers set the overall context for the acceptance and convergence to the LTE standard. Their choice is in agreement with the main criterion for context level selection used in longitudinal research on change suggesting the inseparable role of context and action. The analysis of the events in these two layers is expected to demonstrate how the various aspects of LTE standard adoption and convergence are driven by different stakeholders and groups (i.e. stakeholder alliances) as they seek to obtain outcomes significant to them (Pettigrew, 1990).

Layer 3 (LSTI activities) involves the various trial activities undertaken by the LSTI initiative which is a collaborative effort of various types of stakeholders that includes service providers, network equipment vendors, UE and chipset vendors. LSTI manages the various types of technology trials to prove that the LTE technology is deployable in 
real-world setups and could provide the performance and efficient resource utilization as specified in the standard. Various trial results were fed back to the standard development process to fine-tune the final standard. This layer represents the process aspects of the longitudinal analysis.

The fourth layer (3GPP LTE standard releases) is the outcome of the standardization process and represents the content layer.

\section{Identification of variables}

Variables describing the changes in layer 1 (NGMN) are described in Table 3.4. For each of the variables the study period and a description of variable are presented.

Table 3.4: Variables in the NGMN layer

\begin{tabular}{|l|l|l|l|}
\hline No. & \multicolumn{1}{|c|}{ Variable } & Study Period & \multicolumn{1}{|c|}{ What was determined } \\
\hline 1 & Members & $2006-2009$ & $\begin{array}{l}\text { Number of service providers who have joined the } \\
\text { alliance to define their requirements for next } \\
\text { generation networks }\end{array}$ \\
\hline 2 & Sponsors & $2006-2009$ & $\begin{array}{l}\text { Number of vendors from various types of } \\
\text { industries who are sponsoring the NGMN } \\
\text { activities }\end{array}$ \\
\hline 3 & $\begin{array}{l}\text { Recommendations that } \\
\text { became part of formal } \\
\text { standard }\end{array}$ & $2006-2009$ & $\begin{array}{l}\text { NGMN recommendations and requirements that } \\
\text { were formally accepted as part of the LTE } \\
\text { standard. Their formal acceptance lead to LTE } \\
\text { being adopted by NGMN as first standard } \\
\text { compliant to their requirements. }\end{array}$ \\
& & &
\end{tabular}


Variables describing the change in layer 2 (stakeholders) are listed in Table 3.5.

Table 3.5: Variables in the Stakeholders layer

\begin{tabular}{|c|c|c|c|}
\hline No. & Variable & Study Period & What was determined \\
\hline 1 & $\begin{array}{l}\text { Number of service } \\
\text { providers who have } \\
\text { committed to LTE } \\
\text { adoption } \\
\text { - Existing 3GPP } \\
\text { technology } \\
\text { based service } \\
\text { providers } \\
\text { - Existing non- } \\
\text { 3GPP } \\
\text { technology } \\
\text { based service } \\
\text { providers }\end{array}$ & $2006-2009$ & $\begin{array}{l}\text { Number of service providers, who already have } \\
\text { 3GPP based mobile technologies (i.e. } \\
\text { GSM/UMTS/HSPA), have a clear roadmap to } \\
\text { move to LTE. However this is not true for non- } \\
\text { 3GPP based service providers as their technology } \\
\text { roadmap was leading to UMB. But their } \\
\text { commitment to adopt LTE as next generation } \\
\text { technology depicts a convergence phenomenon. }\end{array}$ \\
\hline 2 & $\begin{array}{l}\text { Number of main service } \\
\text { providers who have } \\
\text { adopted technologies } \\
\text { other than LTE }\end{array}$ & $2006-2009$ & $\begin{array}{l}\text { Number of main service providers who have } \\
\text { adopted technologies other than LTE (i.e. mobile } \\
\text { WiMAX or UMB) }\end{array}$ \\
\hline 3 & $\begin{array}{l}\text { LTE contract winnings } \\
\text { by vendors }\end{array}$ & $2006-2009$ & $\begin{array}{l}\text { LTE product announcements by various vendors } \\
\text { and contract awards by service providers is a key } \\
\text { measure of early success towards convergence to } \\
\text { LTE. }\end{array}$ \\
\hline 4 & $\begin{array}{l}\text { Motivations of } \\
\text { stakeholders to adopt } \\
\text { LTE }\end{array}$ & $2006-2009$ & $\begin{array}{l}\text { Motivations of service providers and various types } \\
\text { of vendors to adopt LTE. }\end{array}$ \\
\hline
\end{tabular}

Variables describing the change in layer 3 (LSTI) are listed in Table 3.6. 
Table 3.6: Variables in the LSTI layer

\begin{tabular}{|c|c|c|c|}
\hline No. & Variable & Study Period & What was determined \\
\hline 1 & $\begin{array}{l}\text { Number of members } \\
\text { stakeholder companies }\end{array}$ & $2006-2009$ & $\begin{array}{l}\text { Number of member companies of LSTI. These are } \\
\text { the companies who are collaborating and trialing } \\
\text { to accelerate the availability of commercial and } \\
\text { interoperable LTE mobile communication } \\
\text { technology. }\end{array}$ \\
\hline 2 & $\begin{array}{l}\text { Industry type of member } \\
\text { stakeholders }\end{array}$ & $2006-2009$ & $\begin{array}{l}\text { Type of industries that LSTI members represent. } \\
\text { This is important as various types of stakeholders } \\
\text { form the open ecosystem for new technology. }\end{array}$ \\
\hline 3 & $\begin{array}{l}\text { Type of trials undertaken } \\
\text { by LSTI members }\end{array}$ & $2006-2009$ & Type of trials undertaken by LSTI members. \\
\hline
\end{tabular}

Variable describing the change in layer 4 (3GPP LTE standard) are listed in Table 3.7.

Table 3.7: Variables in the 3GPP LTE standard layer

\begin{tabular}{|l|l|l|l|}
\hline No. & \multicolumn{1}{|c|}{ Variable } & Study Period & \multicolumn{1}{c|}{ What was determined } \\
\hline 1 & 3GPP standard release & $2004-2008$ & $\begin{array}{l}\text { 3GPP standard release cycle improvement from } \\
\text { release 7 to release 8 and the impact of all the } \\
\text { cycle improvement }\end{array}$ \\
& & $\begin{array}{l}\text { collaborations among various stakeholders to } \\
\text { finalize the standard that is ready to deploy in } \\
\text { commercial setup. }\end{array}$ \\
\hline
\end{tabular}




\section{Identify the linkages between events and variables}

The analysis of the relationship between events and variables across layers is based on the insights from the longitudinal research method:

- emphasis on context, content, and process of change together with their interconnections through time (Pettigrew, 1990)

- a source of change is the asymmetry between levels of context, where processes at different levels of analysis are often observed to have their own momentum, rates, pace and trajectory (Pettigrew, 1990).

- questions such as what, who, where, when, why, and how are the special features of a process vocabulary that can help uncover novel theoretical questions and reveal original findings (Pettigrew et al., 2001)

- the change process is understood as movement from one state to another (Weick \& Quinn, 1999) and should be captured by appropriate variables.

\subsubsection{Identification of constructs}

Siggelkow (2007) argues that the ability to get closer to theoretical constructs is particularly important in the context of longitudinal research that tries to unravel the underlying dynamics of phenomena that play out over time. The research identifies the constructs and their constituent dimensions. The constructs identified by Xu (2007) (see Table 2.1) were examined to determine if those can be utilized to describe the convergence to the LTE standard. Additional constructs were also determined to describe the phenomenon specific to this research. These were determined from a closer analysis 
of the phenomenon observed in the case study in association with the event linkages from the longitudinal research. Specific consideration was paid to the logic and the implications of the linkages among events and variables across the four layers. Additionally, comparison of all newly identified constructs with the ones developed by $\mathrm{Xu}$ (2007) was undertaken.

Adomavicius et al. (2007) and Basole (2009) provide a systematic way of identifying links between events in the case of an ecosystem. However, such systematic approach is not directly applicable in this research since the standard development and convergence process is much focused than the multi-faceted dynamics of business ecosystems in general. Therefore this research follows the logic of the longitudinal case study method in looking for any causal relationship between events at the same or across layers.

\subsubsection{Results and their analysis}

Answers to research questions were formulated based on the identified constructs and case study behind the constructs. Finally the research observations \& executive management insights were formulated. 


\section{Results}

This chapter is divided into four main sections. Section 4.1 provides a brief introduction to the 3GPP LTE standard (a detailed case study on LTE is presented in Appendix A). Section 4.2 depicts the chronological timeline of events that occurred in various layers identified in Section 3.4.6. Section 4.3 provides an analysis of the cross layer linkages between events. Section 4.4 identifies the constructs describing the technology convergence to LTE.

\subsection{A brief description of the 3GPP LTE standard}

The LTE standard deals with the evolutionary steps from Third Generation (3G) to $4 \mathrm{G}$ mobile communication systems. Its development, evolution and adoption are driven by the $3 \mathrm{GPP}$ organization. LTE evolved from the HSPA+ standard; however, direct evolution to LTE from other 3GPP standards is also possible. Non-3GPP networks can also migrate to LTE. The points of difference of the LTE value proposition as compared to existing $3 \mathrm{G}$ mobile communication systems are associated with the following benefits:

- higher throughput

- lower latency for data access

- lower cost per bit of traffic

- ability to deal with a richer mobile service environment

- end to end network based on internet protocol

- more efficient usage of the limited available spectrum. 


\subsubsection{GPP standards body}

3GPP was established in December 1998. 3GPP prepares, approves and maintains the necessary set of Technical Specifications and Technical Reports for the GSM, General Packet Radio Service (GPRS), EDGE, Wideband Code Division Multiple Access (WCDMA), HSPA, and LTE mobile communication systems. 3GPP is a global collaborative standardization body coordinating the joint activities between various regional and national standardization bodies.

For the development of the LTE mobile communication network, the 3GPP procures help from two key support organizations: i) NGMN alliance and ii) LSTI.

\subsubsection{Next Generation Mobile Network (NGMN) alliance}

NGMN is an alliance between the major mobile service providers that was formed in September 2006. NGMN defined the high-level requirements and recommendations for all next-generation broadband wireless networks, and not just LTE. LTE has been developed around NGMN's recommendations. This type of initiative is one of the key differences between LTE and its predecessors, which were primarily vendor-driven technologies. The NGMN alliance's mandate is to complement and support the work within standardization bodies by providing a coherent view of what the operator community is going to require in the decade beyond 2010. More details on NGMN are available in Appendix A. 


\subsubsection{LTE/SAE Trial Initiative (LSTI)}

LSTI is a global, collaborative technology trial initiative focused on accelerating the availability of commercial and interoperable LTE mobile communication systems. The initiative was founded in May 2007 and includes major vendors and service providers and has added more stakeholders (chipset vendors, operators and equipment vendors) since its inception. Vendors and operators began testing LTE early in the development process. The test results are shared with operators and the 3GPP in an effort to improve the standard as the technology is being defined. More details on LSTI and its objectives are available in Appendix A.

\subsubsection{Stakeholders}

The stakeholders involved in the 3GPP LTE standardization include service providers, network equipment vendors, UE vendors, chipset vendors and test equipment vendors. A list of all stakeholders along with their industry type is provided in Section 3.4.4. The analysis of stakeholders is one of the important aspects of this research as the course of actions taken by the various stakeholders defines the context for the successful creation and adoption of LTE. These actions include the initial formation of the NGMN alliance by some of the service providers and the emergence of the LSTI initiative including both vendors and service providers. The formation of alliances among stakeholders is important for the evolution, adoption and market success of newly emerging technologies. Various stakeholders have also contributed to the LTE standard 
development directly - by being members of $3 \mathrm{GPP}$. It is important to point out that the intentions of various stakeholders can be different and need to be carefully examined in each of the cases. The research results include an analysis to examine the specific motivations of the different stakeholders as well as an analysis of the balance of stakeholder representation in the course of LTE standard evolution.

Standardization processes may have unbalanced stakeholder representation. Some stakeholder groups appear to be dominant, while others may experience certain barriers for participation. Stakeholder analysis is based on stakeholder's attributes like Power (P), Legitimacy (L) and Urgency (U) (De Vries et al, 2003).

Due to membership requirements of $3 \mathrm{GPP}$, all stakeholders must contribute into the standardization process and hence all are considered having legitimate intentions. Table 4.1 provides a visual representation of some of the LTE standardization stakeholders from various industry segments. 
Table 4.1: Stakeholder analysis

\begin{tabular}{|c|c|c|c|c|c|c|c|c|c|c|c|c|}
\hline 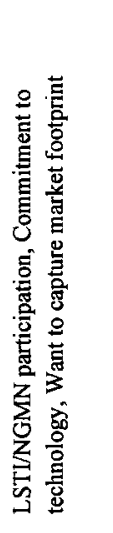 & 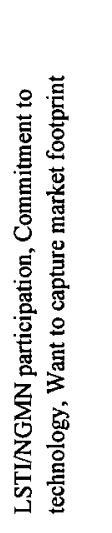 & 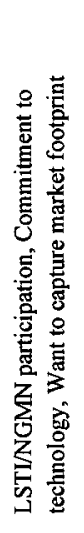 & 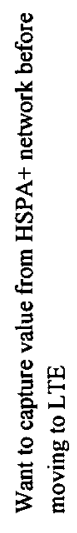 & 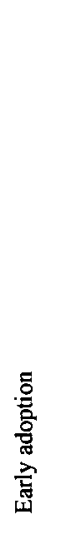 & 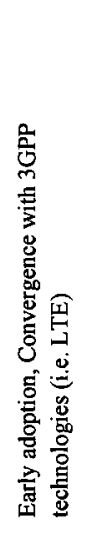 & 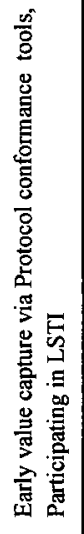 & 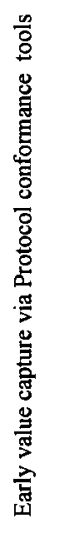 & 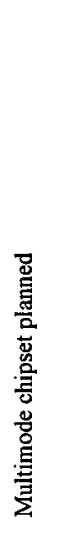 & 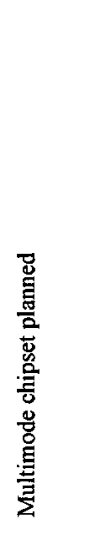 & 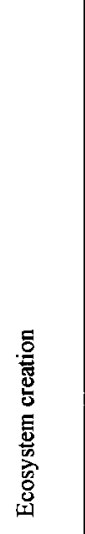 & 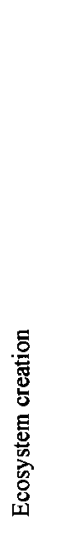 & 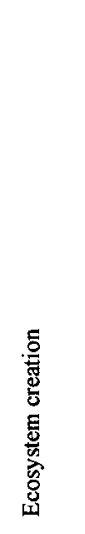 \\
\hline 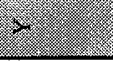 & 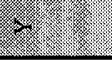 & 3 & 3 & 2 & 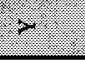 & 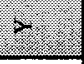 & -5 & $>$ & 3 & 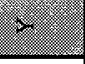 & 8 & 7 \\
\hline 总 & 总 & 兽 & 竞 & 总 & 兽离 & 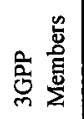 & 总 & 点 & 兽 & 空 & 竞 & 离 \\
\hline & 2 & $x$ & 3. & 3. & 1 & r. & $\therefore$ & 7 & ? & $x$ & $\therefore$ & $>$ \\
\hline 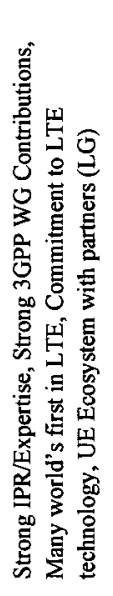 & 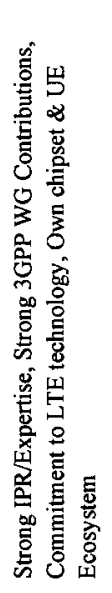 & 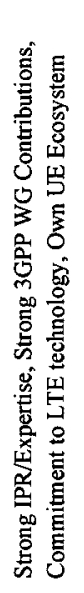 & 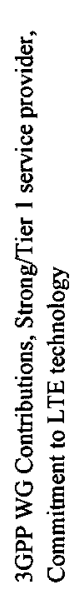 & 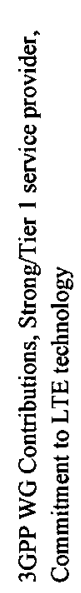 & 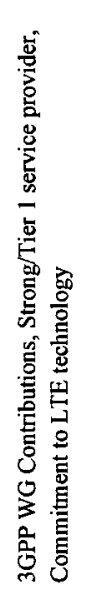 & 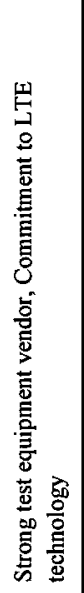 & 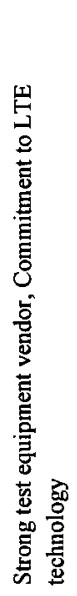 & 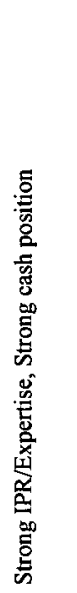 & 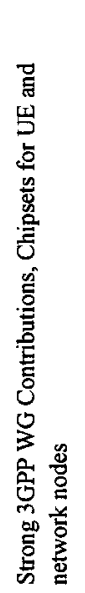 & 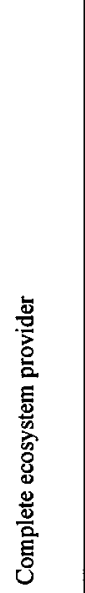 & 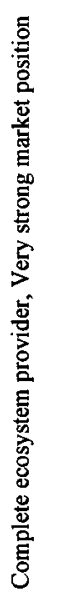 & 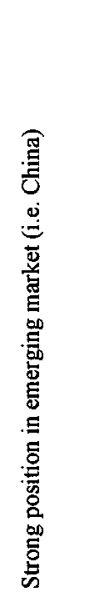 \\
\hline$r$ & $=$ & 3 & s. & $>$ & $>$ & $>$ & 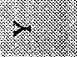 & 2 & & 7 & $\approx$ & 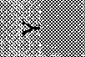 \\
\hline $\begin{array}{l}\text { 总 } \\
\text { z }\end{array}$ & 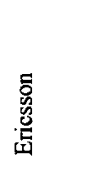 & 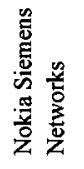 & 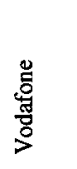 & 总 & 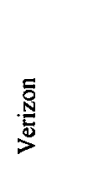 & 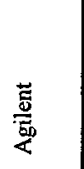 & 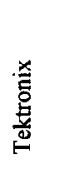 & $\begin{array}{l}\frac{1}{0} \\
\frac{d}{d} \\
\frac{d}{d}\end{array}$ & 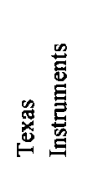 & 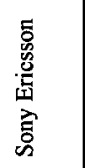 & $\frac{\frac{\pi}{3}}{\frac{\partial}{2}}$ & 崫 \\
\hline$\frac{5}{5}$ & $\frac{g}{g}$ & 袺: & $\begin{array}{l}8.5 \\
\frac{5}{5} .5 \\
\text { है. }\end{array}$ & $\frac{3}{8} \frac{5}{8}$ & 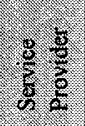 & 解 & $\frac{\frac{3}{4}}{\frac{3}{3}}$ & 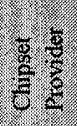 & है & If $\frac{7}{8}$ & 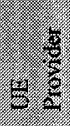 & 8 \\
\hline
\end{tabular}


A straightforward application of the insights found in De Vries et al. (2003) suggests that the majority of the stakeholders could be equally characterized in terms of their power, legitimacy and urgency. Therefore, the analysis of a particular stakeholder cannot be decoupled from its specific actions, i.e. it should be considered within the framework of the longitudinal research method. The results of this analysis are provided in the following sections.

\subsection{Chronological timeline of events}

All events relevant to the evolution of the LTE standard are categorized in four layers. Subsequent sub-sections depict the chronological order of events in each of the layers.

\subsubsection{Chronological timeline of events in the 'NGMN activities' layer}

Events in this layer involve occurrences of events driven by the NGMN alliance providing a view of service providers' understanding for the requirements for the next generation mobile communication networks. Figure 4.1 depicts all relevant events in a chronological order and Table 4.2 provides a description of these events.

Figure 4.1: Chronological timeline of events in the NGMN activities layer

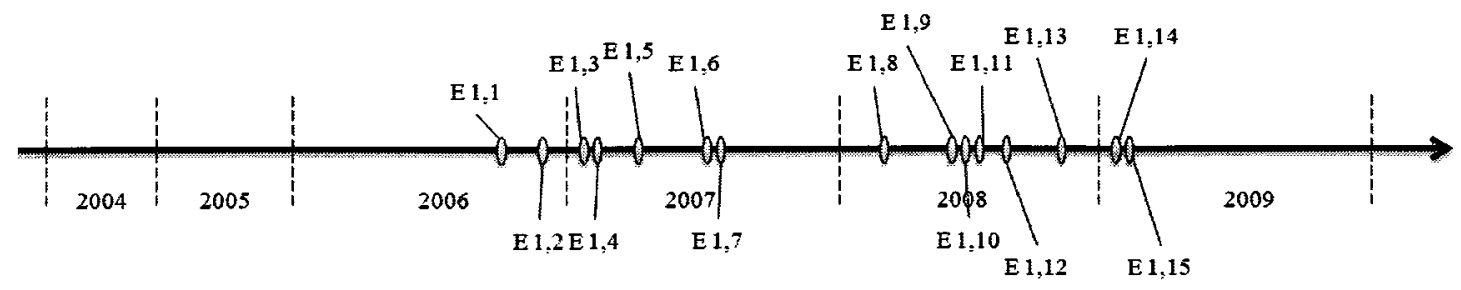


Table 4.2: Description of the events in the NGMN activities layer

\begin{tabular}{|c|c|c|c|}
\hline ID & Date & Event & Reference \\
\hline E 1,1 & $\begin{array}{l}2006 \\
\text { Sep. } 15\end{array}$ & $\begin{array}{l}\text { Seven of the world's biggest wireless carriers } \\
\text { formed the NGMN initiative to provide a } \\
\text { coherent view of what the service providers are } \\
\text { going to require in the decade beyond } 2010\end{array}$ & $\begin{array}{l}\text { http://www.lightreading.com/d } \\
\text { ocument.asp?doc_id }=103857\end{array}$ \\
\hline E 1,2 & $\begin{array}{l}2006 \\
\text { Nov. } 27\end{array}$ & $\begin{array}{l}\text { NGMN appoints industry heavyweight as its } \\
\text { Operating Officer }\end{array}$ & $\begin{array}{l}\text { http://www.ngmn.org/nc/de/ne } \\
\text { ws/ngmnnews/newssingle2/bro } \\
\text { wse/2/article/the-next- } \\
\text { generation-mobile-networks- } \\
\text { ngmn-ltd-appoints-industry- } \\
\text { heavyweight-as-its-operating- } \\
\text { offic.html?tx_ttnews[backPid]= } \\
\text { 20\&cHash=a8ccdbfcfb }\end{array}$ \\
\hline E 1,3 & $\begin{array}{l}2007 \\
\text { Jan. } 11\end{array}$ & $\begin{array}{l}\text { NGMN Releases Version } 3.0 \text { of its White Paper } \\
\text { that provided the global perspective of service } \\
\text { providers around the world and their feedback for } \\
\text { requirements for next generation networks }\end{array}$ & $\begin{array}{l}\text { http:/www.ngmn.org/nc/de/ne } \\
\text { ws/ngmnnews/newssingle } 2 / \text { bro } \\
\text { wse/2/article/ngmn-releases- } \\
\text { version-30-of-its-white- } \\
\text { paper.html?tx_ttnews\%5bback } \\
\text { Pid\%5d=20\&cHash=ecf5fb12d } \\
\text { e }\end{array}$ \\
\hline E 1,4 & $\begin{array}{l}2007 \\
\text { Feb. } 12\end{array}$ & $\begin{array}{l}\text { Alltel Corporation, AT\&T, SK Telecom, } \\
\text { Telecom Italia, and Telefonica SA joined NGMN } \\
\text { as new members. Airvana Inc., Huawei, LG } \\
\text { Electronics, NEC, Samsung, Starent Networks, } \\
\text { and ZTE USA joined NGMN as sponsors, and } \\
\text { the University of Surrey as an advisor }\end{array}$ & $\begin{array}{l}\text { http:/www.ngmn.org/nc/de/ne } \\
\text { ws/ngmnnews/newssingle2/bro } \\
\text { wse/2/article/ngmn-initiative- } \\
\text { gathers-additional- } \\
\text { momentum.html?tx_ttnews[bac } \\
\text { kPid]=20\&cHash=4af9dee616 }\end{array}$ \\
\hline E 1.5 & $\begin{array}{l}2007 \\
\text { Apr. } 17\end{array}$ & $\begin{array}{l}\text { NGMN releases a list of Self Organizing } \\
\text { Networks (SON) use cases for next generation } \\
\text { wireless networks. }\end{array}$ & $\begin{array}{l}\text { http:/www.ngmn.org/uploads/ } \\
\text { media/NGMN_Informative_Lis } \\
\text { t_of_SON_Use_Cases.pdf }\end{array}$ \\
\hline E 1,6 & $\begin{array}{l}2007 \\
\text { Jul. } 15\end{array}$ & $\begin{array}{l}\text { NGMN Alliance identifies its global Spectrum } \\
\text { Requirements for next generation wireless } \\
\text { technologies and recommends that to the }\end{array}$ & $\begin{array}{l}\text { http:/www.ngmn.org/nc/de/ne } \\
\text { ws/ngmnnews/newssingle2/bro } \\
\text { wse/1/article/the-ngmn- }\end{array}$ \\
\hline
\end{tabular}




\begin{tabular}{|c|c|c|c|}
\hline & & International Telecommunications Union (ITU) & $\begin{array}{l}\text { alliance-identifies-its-global- } \\
\text { spectrum- } \\
\text { requirements.html?tx_ttnews } \% \\
5 \text { bbackPid\%5d=20\&cHash=13 } \\
8 d 907994\end{array}$ \\
\hline E 1,7 & $\begin{array}{l}2007 \\
\text { Jul. } 17\end{array}$ & $\begin{array}{l}\text { NGMN reaches a landmark agreement to enhance } \\
\text { the transparency of terms surrounding Intellectual } \\
\text { Property Rights (IPR) for next generation mobile } \\
\text { technologies. }\end{array}$ & $\begin{array}{l}\text { http://www.ngmn.org/nc/de/ne } \\
\text { ws/ngmnnews/newssingle2/bro } \\
\text { wse/1/article/ngmn-announces- } \\
\text { new-sponsors-and- } \\
\text { unprecedented-agreement-on- } \\
\text { innovative-ipr- } \\
\text { regime.html?tx_ttnews\%5bbac } \\
\mathrm{kPid} \% 5 \mathrm{~d}=20 \& c H a s h=b 2 \mathrm{~b} 2398 \\
785\end{array}$ \\
\hline E 1,8 & $\begin{array}{l}2008 \\
\text { Mar. } 6\end{array}$ & $\begin{array}{l}\text { NGMN announced that performance of } \\
\text { LTE/Mobile WiMAX is getting closer to NGMN } \\
\text { requirements. }\end{array}$ & $\begin{array}{l}\text { http://www.ngmn.org/nc/de/ne } \\
\text { ws/ngmnnews/newssingle2/bro } \\
\text { wse/1/article/ngmn-conference- } \\
\text { at-cebit-2008-looks-ahead- } \\
\text { towards-a-bright-future-of- } \\
\text { mobile-broadband- } \\
\text { communications.html?tx_ttnew } \\
\text { s\%5bbackPid\%5d=20\&cHash= } \\
60 \text { eaa60f10 }\end{array}$ \\
\hline E 1,9 & $\begin{array}{l}2008 \\
\text { Jun. } 1\end{array}$ & $\begin{array}{l}\text { NGMN Alliance approves LTE/SAE as its first } \\
\text { compliant technology that broadly meets NGMN } \\
\text { recommendations }\end{array}$ & $\begin{array}{l}\text { http://www.ngmn.org/workprog } \\
\text { ramme/twg.html?type=98 }\end{array}$ \\
\hline E 1,10 & $\begin{array}{l}2008 \\
\text { Jun. } 25- \\
27\end{array}$ & $\begin{array}{l}\text { LTE/SAE technology demos done by major } \\
\text { vendors at the } 2^{\text {nd }} \text { NGMN industry conference. }\end{array}$ & $\begin{array}{l}\text { http://www.ngmn.org/nc/de/ne } \\
\text { ws/ngmnnews/newssingle2/bro } \\
\text { wse/1/article/major-progress- } \\
\text { for-next-generation-of-mobile- } \\
\text { broadband-at-2nd-ngmn- } \\
\text { industry- } \\
\text { conference.html?tx_ttnews\%5b } \\
\text { backPid\%5d=20\&cHash=50a7 } \\
3283 \text { a5 }\end{array}$ \\
\hline E 1,11 & 2008 & NGMN established partnership with GSM & http://www.ngmn.org/aboutus/l \\
\hline
\end{tabular}




\begin{tabular}{|c|c|c|c|}
\hline & Jun. & $\begin{array}{l}\text { Association (GSMA), Open Mobile Terminal } \\
\text { Platform (OMTP), UMTS forum \& Femto forum } \\
\text { to attain the goal of a coherent vision for the } \\
\text { mobile evolution beyond } 3 \mathrm{G}\end{array}$ & iaisons.html \\
\hline E 1,12 & $\begin{array}{l}2008 \\
\text { Jul. } 18\end{array}$ & $\begin{array}{l}\text { Sprint leaves NGMN because the alliance } \\
\text { endorsed LTE technology for } 4 \mathrm{G} \text { networks }\end{array}$ & $\begin{array}{l}\text { http://www.telegeography.com/ } \\
\text { cu/article.php?article_id=24113 }\end{array}$ \\
\hline E 1,13 & $\begin{array}{l}2008 \\
\text { Nov } 4\end{array}$ & $\begin{array}{l}\text { Cambridge Broadband Networks Limited is the } \\
\text { first backhaul-focused technology vendor to join } \\
\text { the NGMN. }\end{array}$ & $\begin{array}{l}\text { http://www.unstrung.com/docu } \\
\text { ment.asp?doc_id }=167268\end{array}$ \\
\hline E 1,14 & $\begin{array}{l}2009 \\
\text { Jan. } 19\end{array}$ & $\begin{array}{l}\text { NGMN releases final requirements on Self } \\
\text { Organizing Networks }\end{array}$ & $\begin{array}{l}\text { http://www.ngmn.org/nc/de/ne } \\
\text { ws/ngmnnews/newssingle2/arti } \\
\text { cle/ngmn-releases- } \\
\text { requirements-on-self- } \\
\text { optimising- } \\
\text { networks.html?tx_ttnews } \% 5 \text { bba } \\
\text { ckPid } \% 5 d=20 \& c H a s h=4 c f c d e f \\
0 \text { af }\end{array}$ \\
\hline E 1,15 & $\begin{array}{l}2009 \\
\text { Feb. } 12\end{array}$ & $\begin{array}{l}\text { NGMN releases requirements for Initial Terminal } \\
\text { Device Definition }\end{array}$ & $\begin{array}{l}\text { http://www.ngmn.org/nc/de/ne } \\
\text { ws/ngmnnews/newssingle2/arti } \\
\text { cle/ngmn-releases- } \\
\text { requirements-for-initial- } \\
\text { terminal-device- } \\
\text { definition.html?tx_ttnews\%5bb } \\
\text { ackPid\%5d=20\&cHash=279e8 } \\
4203 \mathrm{~d}\end{array}$ \\
\hline
\end{tabular}

NGMN Members

NGMN members are the mobile service providers. Members of the NGMN alliance represent well over one half ${ }^{5}$ of the total mobile subscriber base world-wide. These

${ }^{5}$ NGMN FAQ, http://www.ngmn.org/de/aboutus/faq.html, last accessed on June $30^{\text {th }} 2009$. 
members are 19 in total. Table 4.3 lists the member service providers (many of the service providers have operations in more than one country).

Table 4.3: NGMN alliance members ${ }^{6}$

\begin{tabular}{|l|l|}
\hline \multicolumn{1}{|c|}{$\begin{array}{c}\text { Geographic locations } \\
\text { where member are based }\end{array}$} & \multicolumn{1}{|c|}{ Members (as of June 30 ${ }^{\text {th }}$ 2009) } \\
\hline North America & AT\&T, Bell Canada, SkyTerra Communications, TELUS Corp. \\
\hline Europe & $\begin{array}{l}\text { KPN, Orange (France telecom group), T-Mobile International, Telecom } \\
\text { Italia, Telefonica, TeliaSonera, Vodafone Group (represents the interests } \\
\text { of Verizon) }\end{array}$ \\
\hline Asia-pacific & $\begin{array}{l}\text { China Mobile Communications, KDDI Corporation, KT Corp., LG } \\
\text { Telecom, NTT DoCoMo, Reliance Communications, SK Telecom, Telstra } \\
\text { Corp. }\end{array}$ \\
\hline
\end{tabular}

Sprint was one of the founders of the NGMN alliance; however its name is missing from the members' list. Sprint decided to leave the alliance in July 2008 right after NGMN approved LTE as its first compliant technology. This is partly due to Sprint's decision to adopt WiMAX as choice of technology for their next generation network. Major mobile service providers identified LTE to be their choice of $4 \mathrm{G}$ mobile communication technology that meets their requirements.

Acceptance and adoption of LTE by these NGMN members who represent more than half of mobile subscribers of the world has enabled them to create and deliver a next generation mobile communication networks and services by creating a sustainable and

\footnotetext{
${ }^{6}$ List of NGMN members, http://www.ngmn.org/aboutus/partners.html, last accessed on June $30^{\text {th }} 2009$.
} 
successful mobile broadband ecosystem ${ }^{7}$. Additionally, members like Bell Canada, Telus, KDDI and Verizon (represented by Vodafone) have non-3GPP technologies deployed as their $2 \mathrm{G}$ or $3 \mathrm{G}$ networks. Their participation in the alliance has set the way for convergence to LTE.

\section{NGMN Sponsors}

NGMN sponsors are the various types of vendors. Sponsors of the NGMN alliance account for more than $90 \%$ of the global footprint of mobile network deployments. These sponsors are 35 in total. Table 4.4 lists the sponsors.

Table 4.4: NGMN alliance sponsors8

\begin{tabular}{|l|l|}
\hline \multicolumn{1}{|c|}{$\begin{array}{c}\text { Geographic locations } \\
\text { where sponsors are based }\end{array}$} & \multicolumn{1}{|c|}{$\begin{array}{c}\text { Sponsors (as of June 30 } \\
\text { th 2009) }\end{array}$} \\
\hline North America & $\begin{array}{l}\text { Airvana, Cisco Systems, Juniper Networks, Motorola, Nortel, Powerwave } \\
\text { Technologies, Qualcomm, RIM, Starent Networks, Telcordia, Tellabs }\end{array}$ \\
\hline Europe & $\begin{array}{l}\text { Alcatel-Lucent, Anritsu, Cambridge Broadband Networks, CETECOM, } \\
\text { Communology, Ericsson, mimoOn, Nokia Corp., Nokia Siemens } \\
\text { Networks, Rohde \& Schwarz, Sony Ericsson Mobile Communications, } \\
\text { ST-Ericsson, Ubidyne }\end{array}$ \\
\hline Asia-Pacific & $\begin{array}{l}\text { Datang Mobile Communications, Fujitsu, Hitachi Communication } \\
\text { Technologies, Huawei Technologies, LG Electronics, NEC Corp., Potevio } \\
\text { Institute of Technology Company, RAD Group, Samsung Electronics, } \\
\text { Telecommunication Metrology Center of MII, ZTE Corp. }\end{array}$ \\
\hline
\end{tabular}

${ }^{7}$ NGMN Ecosystem working group, http://www.ngmn.org/workprogramme/ecosystem.html last accessed on 30th June 2009.

${ }^{8}$ List of NGMN sponsors, http://www.ngmn.org/aboutus/partners/sponsors.html, last accessed on June $30^{\text {th }}$ 2009. 
NGMN sponsors include vendors from various industry types. These include network equipment vendors, UE vendors, chipset vendors and test equipment vendors. Their participation in the alliance has set the precedence for the creation of an ecosystem for adoption of LTE.

An agreement ${ }^{9}$ among NGMN members and sponsors allowed them access to each other's IPR at very nominal fees. The LTE IPR license framework encompasses the principle of Fair, Reasonable And Non-Discriminatory (FRAND) terms for essential patents. This allows a single digit percentage royalty level for LTE handsets. For other devices with embedded LTE capabilities, a single digit dollar value as royalty is allowed.

\section{Formal standardization of NGMN recommendations}

NGMN provided recommendations on self organizing networks (SON) to help service providers reduce operations expenditure to run their networks and in turn earning more

revenue. SON-related recommendations are released as 3 GPP specifications ${ }^{10} \operatorname{TS}^{2} 2.500$ to TS32.503, TS32.511, TS32.521 to TS32.523 and TS32.541 to TS32.543.

${ }^{9}$ Wireless leaders commit to framework for LTE IPR licensing, http://www.ciol.com/Technology/Mobility/News-Reports/Wireless-leaders-commit-to-framework-for-

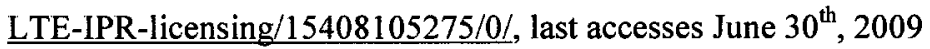
${ }^{10}$ 3GPP Specifications, 32 Series, http://www.3gpp.org/ftp/Specs/html-info/32-series.htm, last accessed June $30^{\text {th }}, 2009$. 
Specifications for user equipment are standardized in 3GPP specifications ${ }^{11}$ TS36.101 and TS36.306.

\subsubsection{Chronological timeline of events in the stakeholders layer}

Events in this layer provide the actions of all relevant stakeholders driven by their economical, technological and business motivations for joining or resisting joining the convergence to LTE in association with their specific product development strategies. This layer is divided into three sub-layers representing the type of stakeholders, namely, service providers, network equipment vendors, UE and chipset vendors.

\section{Service providers sub-layer}

The service providers sub-layer includes the service-provider-specific events. Figure 4.2 depicts the events in a chronological order and Table 4.5 provides a description of the events.

\footnotetext{
11 3GPP Specifications, 36 Series, http://www.3gpp.org/ftp/Specs/html-info/36-series.htm, last accessed June $30^{\text {th }}, 2009$.
} 
Figure 4.2: Chronological timeline of events in the stakeholder: service provider sub-layer

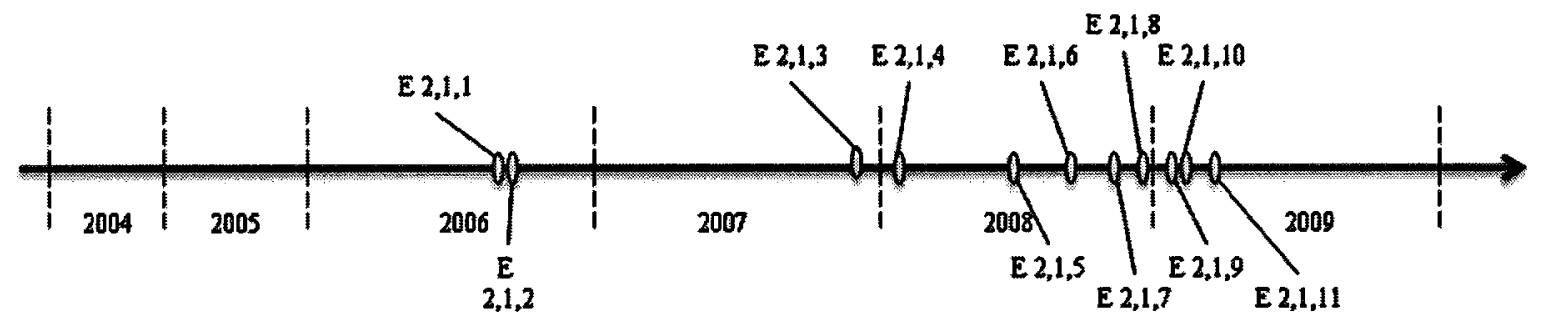

Table 4.5: Description of the events in the stakeholder: service provider layer

\begin{tabular}{|c|l|l|l|}
\hline ID & \multicolumn{1}{|c|}{ Date } & \multicolumn{1}{|c|}{ Event } & \multicolumn{1}{c|}{ Reference } \\
\hline E 2,1,1 & $\begin{array}{l}2006 \text { Aug. } \\
9\end{array}$ & $\begin{array}{l}\text { Sprint plans to spend \$3bn over the next } \\
\text { two years to build a 4G wireless network } \\
\text { using WiMAX technology }\end{array}$ & $\begin{array}{l}\text { http://networks.silicon.com/mobile/ } \\
0,39024665,39161289,00 . h t m\end{array}$ \\
\hline E 2,1,2 & $\begin{array}{l}2006 \text { Sep. } \\
15\end{array}$ & $\begin{array}{l}\text { T-Mobile and Sprint founded the NGMN } \\
\text { alliance (along with 5 other operators) to } \\
\text { work on the operators' requirements for } \\
\text { next generation wireless networks. }\end{array}$ & $\begin{array}{l}\text { http://www.lightreading.com/docum } \\
\text { ent.asp?doc_id=103857 }\end{array}$ \\
\hline E 2,1,3 & $\begin{array}{l}2007 \text { Nov. } \\
29\end{array}$ & $\begin{array}{l}\text { Verizon Selects LTE as 4G Wireless } \\
\text { Broadband Direction }\end{array}$ & $\begin{array}{l}\text { http://news.vzw.com/news/2007/11/ } \\
\text { pr2007-11-29.html }\end{array}$ \\
\hline E 2,1,4 & $\begin{array}{l}2008 \text { Feb } \\
12\end{array}$ & $\begin{array}{l}\text { Vodafone Eyes HSPA+ as a key technology } \\
\text { to head the mobile broadband race and then } \\
\text { moves to LTE }\end{array}$ & $\begin{array}{l}\text { http://www.3g.co.uk/PR/Feb2008/5 } \\
780 . h t m ~\end{array}$ \\
\hline E 2,1,5 & $\begin{array}{l}2008 \text { Jul. } \\
18\end{array}$ & $\begin{array}{l}\text { Sprint leaves NGMN because the alliance } \\
\text { endorsed LTE technology for 4G networks }\end{array}$ & $\begin{array}{l}\text { http://www.telegeography.com/cu/ar } \\
\text { ticle.php?article_id=24113 }\end{array}$ \\
\hline E 2,1,6 & $\begin{array}{l}2008 \text { Oct. } \\
10\end{array}$ & $\begin{array}{l}\text { Bell and Telus declared a joint plan to move } \\
\text { to HSPA in 2010 and then to LTE in 2012. } \\
\text { Select NSN and Huawei as vendors. }\end{array}$ & $\begin{array}{l}\text { http://www.cbc.ca/money/story/200 } \\
8 / 10 / 10 / \text { bell-telus-gsm.html }\end{array}$ \\
\hline E 2,1,7 & $\begin{array}{l}2008 \text { Nov. } \\
5\end{array}$ & $\begin{array}{l}\text { CTO of T-Mobile confirms the investment } \\
\text { in LTE, not HSPA+ }\end{array}$ & $\begin{array}{l}\text { http://www.ngmn.org/nc/news/partn } \\
\text { ernews/newssingle0/article/t- }\end{array}$ \\
\hline
\end{tabular}




\begin{tabular}{|c|c|c|c|}
\hline & & & $\begin{array}{l}\text { mobile-cto-ill-invest-in-lte-not- } \\
\text { hspa.html?tx_ttnews[backPid] }=3 \& \mathrm{c} \\
\text { Hash }=34 \mathrm{cf} 539 \mathrm{e} 3 \mathrm{e}\end{array}$ \\
\hline E $2,1,8$ & $\begin{array}{l}2008 \text { Dec. } \\
3\end{array}$ & $\begin{array}{l}\text { KDDI chooses LTE for next-generation } \\
\text { mobile communication systems, selects } \\
\text { Hitachi as the development vendor }\end{array}$ & $\begin{array}{l}\text { http://www.kddi.com/english/corpor } \\
\text { ate/news_release/2008/1203/ }\end{array}$ \\
\hline E $2,1,9$ & $\begin{array}{l}2009 \text { Feb. } \\
17\end{array}$ & $\begin{array}{l}\text { T-Mobile re-iterate their commitment to } \\
\text { LTE and announced that they expect initial } \\
\text { deployment by } 2010 \text { in their network }\end{array}$ & $\begin{array}{l}\text { http://www.unstrung.com/document. } \\
\text { asp?doc_id=172272 }\end{array}$ \\
\hline $\begin{array}{l}\mathrm{E} \\
2,1,10\end{array}$ & $\begin{array}{l}2009 \text { Feb. } \\
18\end{array}$ & $\begin{array}{l}\text { Verizon CTO Dick Lynch announces LTE } \\
\text { deployment plans and announces the } \\
\text { vendors for RAN, EPC and IMS }\end{array}$ & $\begin{array}{l}\text { http://news.vzw.com/news/2009/02/ } \\
\text { pr2009-02-18.html }\end{array}$ \\
\hline $\begin{array}{l}\mathrm{E} \\
2,1,11\end{array}$ & $\begin{array}{l}2009 \text { Mar. } \\
8\end{array}$ & $\begin{array}{l}\text { Global mobile Suppliers Association (GSA) } \\
\text { announced that } 26 \text { network operators have } \\
\text { committed to deploy } 3 \text { GPP LTE systems }\end{array}$ & $\begin{array}{l}\text { http://www.intomobile.com/2009/03 } \\
\text { /08/gsa-confirms-26-operators- } \\
\text { committed-to-lte.html } \\
\text { http://www.gsacom.com/news/gsa_ } \\
\text { 265.php4 }\end{array}$ \\
\hline
\end{tabular}

\section{Network equipment vendors sub-layer}

The network equipment vendors sub-layer includes network equipment vendors specific events. Figure 4.3 depicts the events in a chronological order and Table 4.6 provides a description of the events.

Figure 4.3: Chronological timeline of events in the stakeholder: Network equipment vendors sub-layer

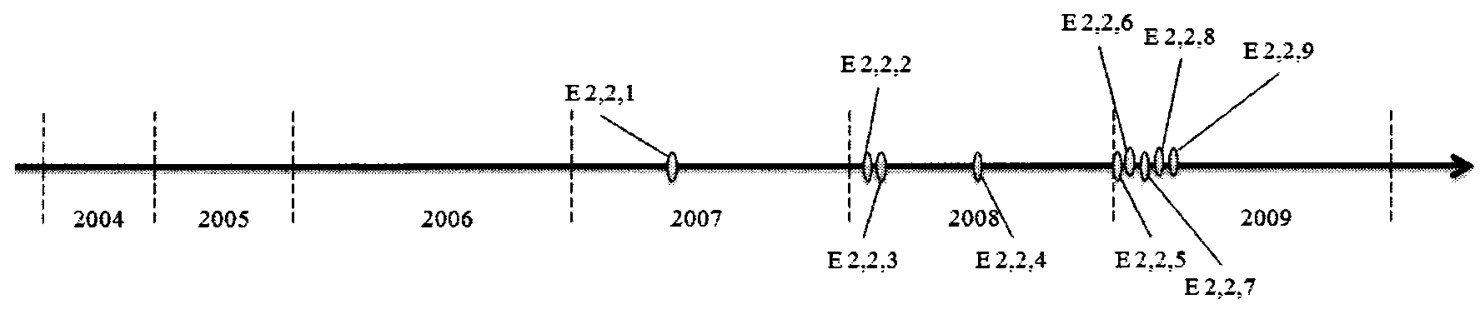


Table 4.6: Description of the events in the stakeholder: Network equipment vendors sublayer

\begin{tabular}{|c|c|c|c|}
\hline ID & Date & Event & Reference \\
\hline $\begin{array}{l}\mathrm{E} \\
2,2,1\end{array}$ & $\begin{array}{l}2007 \\
\text { May. }\end{array}$ & $\begin{array}{l}\text { LSTI Initiative launched in May } 2007 \text { by } \\
\text { leading telecommunications companies } \\
\text { Alcatel-Lucent, Ericsson, Nokia, Nokia } \\
\text { Siemens Networks, Nortel, Orange, T-Mobile } \\
\text { and Vodafone. }\end{array}$ & $\begin{array}{l}\text { http://www.lstiforum.com/media/ne } \\
\text { ws.html?listNum=159 }\end{array}$ \\
\hline $\begin{array}{l}\mathrm{E} \\
2,2,2\end{array}$ & $\begin{array}{l}2008 \text { Jan } \\
30\end{array}$ & $\begin{array}{l}\text { Ericsson first to demonstrate LTE in both } \\
\text { frequency division duplex (FDD) and time } \\
\text { division duplex (TDD) modes on the same base } \\
\text { station platform }\end{array}$ & $\begin{array}{l}\text { http://www.ericsson.com/ericsson/pr } \\
\text { ess/releases/20080130- } \\
1186619 . \text { shtml }\end{array}$ \\
\hline $\begin{array}{l}\mathrm{E} \\
2,2,3\end{array}$ & $\begin{array}{l}2008 \mathrm{Feb} \\
16\end{array}$ & $\begin{array}{l}\text { Nokia Siemens Networks showcases LTE } \\
\text { interoperability using Qualcomm technology }\end{array}$ & $\begin{array}{l}\text { http://www.nokiasiemensnetworks.c } \\
\text { om/global/Press/Press+releases/new } \\
\text { s- } \\
\text { archive/Nokia+Siemens+Networks+ } \\
\text { showcases+LTE+interoperability+u } \\
\text { sing+Qualcomm+technology.htm }\end{array}$ \\
\hline $\begin{array}{l}\mathrm{E} \\
2,2,4\end{array}$ & $\begin{array}{l}2008 \\
\text { Aug. } 27\end{array}$ & $\begin{array}{l}\text { Nortel completed the first live LTE handoff } \\
\text { between cell sites. }\end{array}$ & $\begin{array}{l}\text { http://www.fiercebroadbandwireless } \\
\text {.com/story/nortel-completes-live-lte- } \\
\text { handoff/2008-08-27 }\end{array}$ \\
\hline $\begin{array}{l}\mathrm{E} \\
2,2,5\end{array}$ & $\begin{array}{l}2009 \\
\text { Jan. } 15\end{array}$ & $\begin{array}{l}\text { Huawei wins world' s first } 4 \mathrm{G} / \mathrm{LTE} \text { commercial } \\
\text { contract from TeliaSonera }\end{array}$ & $\begin{array}{l}\text { http://www.huawei.com/news/view. } \\
\text { do?id=10737\&cid=42 }\end{array}$ \\
\hline $\begin{array}{l}\mathrm{E} \\
2,2,6\end{array}$ & $2009 \mathrm{Feb}$ & $\begin{array}{l}\text { Starent Networks and Samsung demonstrate } \\
\text { first multi-vendor 4G LTE EPC-RAN }\end{array}$ & $\begin{array}{l}\text { http://www.starentnetworks.com/en/ } \\
\text { press.php?id=125 }\end{array}$ \\
\hline $\begin{array}{l}\mathrm{E} \\
2,2,7\end{array}$ & $\begin{array}{l}2009 \mathrm{Feb} \\
16\end{array}$ & $\begin{array}{l}\text { Alcatel-Lucent (ALU) forms "ngConnect" } \\
\text { group to push LTE applications }\end{array}$ & $\begin{array}{l}\text { http://www.networkworld.com/news } \\
\text { /2009/021609-alcatel-forms-group- } \\
\text { to-push.html } \\
\text { http://www.ngconnect.org/ }\end{array}$ \\
\hline $\begin{array}{l}\mathrm{E} \\
2,2,8\end{array}$ & $\begin{array}{l}2009 \text { Feb } \\
18\end{array}$ & $\begin{array}{l}\text { Ericsson, ALU and Starent won the initial LTE } \\
\text { contract from Verizon. Nortel was left out of } \\
\text { the contract due to its financial troubles, even }\end{array}$ & $\begin{array}{l}\text { http://news.vzw.com/news/2009/02/ } \\
\text { pr2009-02-18.html }\end{array}$ \\
\hline
\end{tabular}




\begin{tabular}{|l|l|l|l|}
\hline & & though Nortel's solution was considered good & \\
\hline E & $\begin{array}{l}2009 \mathrm{Feb} \\
2,2,9\end{array}$ & $\begin{array}{l}\text { Motorola Trials TDD-LTE in order to meet the } \\
\text { future needs of operators in China }\end{array}$ & $\begin{array}{l}\text { http://www.unstrung.com/document. } \\
\text { asp?doc_id=172589 }\end{array}$ \\
\hline
\end{tabular}

\section{UE/Chipset vendors sub-layer}

The UE/Chipset vendor sub layer includes the UE and chipset vendor specific events.

Figure 4.4 depicts the events in a chronological order and Table 4.7 provides a description of the events.

Figure 4.4: Chronological timeline of events in the stakeholder: UE/chipset vendors sub-layer

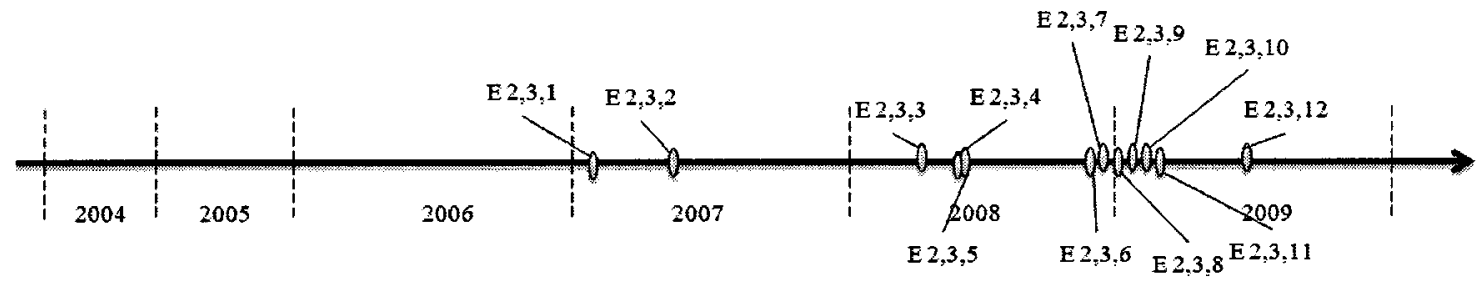

Table 4.7: Description of the events in the stakeholder: UE/chipset vendors sub-layer

\begin{tabular}{|c|c|c|c|}
\hline ID & Date & Event & Reference \\
\hline $\begin{array}{l}\mathrm{E} \\
2,3,1\end{array}$ & $\begin{array}{l}2007 \\
\text { Jan. } 9\end{array}$ & $\begin{array}{l}\text { Apple reinvents the Phone with iPhone - supports } \\
\text { GSM and EDGE }\end{array}$ & $\begin{array}{l}\text { http://www.apple.com/pr/library/20 } \\
\text { 07/01/09iphone.html }\end{array}$ \\
\hline $\begin{array}{l}\mathrm{E} \\
2,3,2\end{array}$ & $\begin{array}{l}2007 \\
\text { May. }\end{array}$ & $\begin{array}{l}\text { LSTI Initiative launched in May } 2007 \text { by leading } \\
\text { telecommunications companies Alcatel-Lucent, } \\
\text { Ericsson, Nokia, Nokia Siemens Networks, Nortel, } \\
\text { Orange, T-Mobile and Vodafone. }\end{array}$ & $\begin{array}{l}\text { http://www.lstiforum.com/media/n } \\
\text { ews.html?listNum=159 }\end{array}$ \\
\hline $\begin{array}{l}\text { E } \\
2,3,3\end{array}$ & $\begin{array}{l}2008 \\
\text { Apr. }\end{array}$ & $\begin{array}{l}\text { Ericsson introduces world's first commercial LTE } \\
\text { platform (M700) for mobile devices }\end{array}$ & $\begin{array}{l}\text { http://www.stericsson.com/platfor } \\
\text { ms/lte_m700.jsp } \\
\text { http://money.aol.com/news/articles } \\
\text { /qp/pr/_a/ericsson-introduces- }\end{array}$ \\
\hline
\end{tabular}




\begin{tabular}{|c|c|c|c|}
\hline & & & worlds-first/rfid87685305 \\
\hline $\begin{array}{l}\mathbf{E} \\
2,3,4\end{array}$ & $\begin{array}{l}2008 \\
\text { Jun. } 9\end{array}$ & $\begin{array}{l}\text { Apple introduces the new iPhone } 3 \mathrm{G} \text { - supports } \\
\text { GSM, EDGE and HSDPA }\end{array}$ & $\begin{array}{l}\text { http://www.apple.com/pr/library/20 } \\
\text { 08/06/09iphone.html }\end{array}$ \\
\hline $\begin{array}{l}\mathrm{E} \\
2,3,5\end{array}$ & $\begin{array}{l}2008 \\
\text { Jun. } \\
12\end{array}$ & $\begin{array}{l}\text { NXP BV is working on the Nexperia PNX6910, a } \\
\text { cellular software modem, which the company } \\
\text { claimed is capable of achieving data transfer rates } \\
\text { of } 150 \text { Mbits per second downlink and } 50 \text { Mbits } \\
\text { per second uplink, and supports multi-mode } \\
\text { LTE/HSPA/UMTS/EDGE/GPRS/GSM capability }\end{array}$ & $\begin{array}{l}\text { http://www.mobilehandsetdesignlin } \\
\text { e.com/showArticle.jhtml;jsessionid } \\
=3 \text { UQ2XRYYFYJWCQSNDLPSK } \\
\text { HSCJUNN2JVN?articleID=20840 } \\
\text { 3575\&queryText=LTE }\end{array}$ \\
\hline $\begin{array}{l}\mathrm{E} \\
2,3,6\end{array}$ & $\begin{array}{l}2008 \\
\text { Nov. } \\
13\end{array}$ & $\begin{array}{l}\text { Qualcomm halts UMB project and putting } \\
\text { resources into LTE technology instead as big } \\
\text { service-provider customers, such as Verizon } \\
\text { Wireless, have chosen a rival technology called } \\
\text { Long Term Evolution for its next-generation high- } \\
\text { speed network }\end{array}$ & $\begin{array}{l}\text { http://www.reuters.com/article/mar } \\
\text { ketsNews/idUSN13359694200811 } \\
\text { 13?rpc=401\& }\end{array}$ \\
\hline $\begin{array}{l}\mathrm{E} \\
2,3,7\end{array}$ & $\begin{array}{l}2008 \\
\text { Dec } 9\end{array}$ & $\begin{array}{l}\text { LG develops world's first LTE handset modem } \\
\text { chip }\end{array}$ & $\begin{array}{l}\text { http://www.lge.com/about/press_re } \\
\text { lease/detail/21031.jhtml }\end{array}$ \\
\hline $\begin{array}{l}\mathrm{E} \\
2,3,8\end{array}$ & $\begin{array}{l}2009 \\
\text { Jan. } 8\end{array}$ & $\begin{array}{l}\text { Nokia ends production of its only WiMAX device } \\
\text { and will put their effort on LTE devices. }\end{array}$ & $\begin{array}{l}\text { http://www.pcworld.com/businessc } \\
\text { enter/article/156707/nokia_ends_pr } \\
\text { oduction_of_its_only_wimax_devi } \\
\text { ce.html }\end{array}$ \\
\hline $\begin{array}{l}\mathrm{E} \\
2,3,9\end{array}$ & $\begin{array}{l}2009 \\
\text { Feb. } \\
12\end{array}$ & $\begin{array}{l}\text { ST-Ericsson born as wireless-semiconductor } \\
\text { industry leader. It includes merger of Ericsson } \\
\text { Mobile Platforms and ST-NXP Wireless. }\end{array}$ & $\begin{array}{l}\text { http://www.stericsson.com/press_r } \\
\text { eleases/ST_Ericsson_born.jsp }\end{array}$ \\
\hline $\begin{array}{l}\mathrm{E} \\
2,3,10\end{array}$ & $\begin{array}{l}2009 \\
\text { Feb. } \\
17\end{array}$ & $\begin{array}{l}\text { ST-Ericsson and Nokia announce cooperation to } \\
\text { provide next-generation smartphone platform for } \\
\text { Symbian foundation }\end{array}$ & $\begin{array}{l}\text { http://www.stericsson.com/press_r } \\
\text { eleases/Smartphone_symbian_Nok } \\
\text { ia.jsp }\end{array}$ \\
\hline $\begin{array}{l}\mathrm{E} \\
2,3,11\end{array}$ & $\begin{array}{l}2009 \\
\text { Mar. } \\
5\end{array}$ & $\begin{array}{l}\text { Nokia affirms LTE commitment, dismisses } \\
\text { WiMAX. Nokia affirmed its commitment to Long } \\
\text { Term Evolution (LTE) technology and said it } \\
\text { would have devices for LTE networks in } 2010\end{array}$ & $\begin{array}{l}\text { http://www.fiercewireless.com/stor } \\
\text { y/nokia-affirms-lte-committment- } \\
\text { dismisses-wimax/2009-03- } \\
\text { 05?utm_medium=rss\&utm_source } \\
=\text { rss\&cmp-id=OTC-RSS-FW0 }\end{array}$ \\
\hline $\begin{array}{l}\mathrm{E} \\
2,3,12\end{array}$ & $\begin{array}{l}2009 \\
\text { Jun. } 8\end{array}$ & $\begin{array}{l}\text { Apple announces the new iPhone 3GS - supports } \\
\text { GSM, EDGE and HSDPA }\end{array}$ & $\begin{array}{l}\text { http://www.apple.com/pr/library/20 } \\
\text { 09/06/08iphone.html }\end{array}$ \\
\hline
\end{tabular}




\section{Number of key service providers who have committed to LTE adoption}

LTE has emerged as the choice of mobile communication standard for many of the major service providers around the world. These service providers include the ones who have existing 3GPP technologies (GSM, W-CDMA/UMTS, HSPA) based networks and the ones who have non-3GPP technologies (CDMA, 1xDO) based networks. LTE is their next generation network to further the user experience by enabling more demanding applications such as interactive mobile TV, mobile video blogging, online advanced games and professional services.

As of April $15^{\text {th }} 2009,30$ of the world's major service providers have committed ${ }^{12}$ to LTE. Table 4.8 lists those service providers.

Table 4.8: Service providers' commitment to LTE

\begin{tabular}{|l|l|}
\hline \multicolumn{1}{|c|}{ Service providers committed to LTE } & \multicolumn{1}{c|}{ Existing network } \\
\hline AT\&T Mobility, China Mobile, Cox, HK CSL Ltd, & 3GPP technologies based (GSM, EDGE, \\
Hutchison 3, NTT DoCoMo, Orange, PCCW, Piltel, \\
RogersWireless, SmarTone-Vodafone, Tele2 Sweden, \\
$\begin{array}{l}\text { Telecom Italia, Telefonica O2, Telenor Sweden, TeliaSonera, } \\
\text { Telstra, T-Mobile, Vodafone }\end{array}$ & W-CDMA, HSPA) \\
\hline $\begin{array}{l}\text { Aircell, Bell Canada, Century Tel, China Telecom, KDDI, } \\
\text { KTF, MetroPCS, SK Telecom, Telecom NZ, Telus, Verizon }\end{array}$ & $\begin{array}{l}\text { 3GPP2 technologies based (CDMA, 1x DO } \\
\text { Rev0, 1xDO Rev A) }\end{array}$ \\
\hline
\end{tabular}

${ }^{12}$ Enabling societal and personal communications for a changing world, page 8.

http://www.atis.org/webinar/LTEWebinar.pdf last accessed on June $30^{\text {th }} 2009$. 
The Global mobile Suppliers Association has noted that up to $12^{13}$ LTE networks are expected to launch commercial services in 2010 . These services will cover North America, Europe and Asia.

\section{Service providers who have adopted technologies other than LTE}

LTE is the natural evolution path for 3GPP based $2 \mathrm{G} / 3 \mathrm{G}$ technologies. Similarly, Ultra Mobile Broadband (UMB) was the natural evolution path for 3GPP2 based 2G/3G technologies. However, due to decision by main 3GPP2 based service providers to converge to LTE, Qualcomm (promoter of UMB) halted ${ }^{14}$ the development of UMB in November 2008.

Not every 3GPP2 based service provider has embraced LTE as their $4 \mathrm{G}$ network. The development of the WiMAX standard did not involve trials similar to those LSTI conducted for the LTE standard and this can be attributed to relatively lower adoption of WiMAX as compared to the LTE standard. Sprint ${ }^{15}$ is one service provider who has

\footnotetext{
${ }^{13} \mathrm{http://www.gsacom.com/news/gsa} \mathrm{269.php4,} \mathrm{last} \mathrm{accessed} \mathrm{on} \mathrm{June} 30^{\text {th }} 2009$. ${ }^{14}$ Qualcomm halts UMB project, http://www.forbes.com/feeds/afx/2008/11/13/afx5689809.html, last accessed on June $30^{\text {th }} 2009$.

${ }^{15}$ Wikipedia entry on Sprint-Nextel, http://en.wikipedia.org/wiki/Sprint_Nextel, last accessed on June $30^{\text {th }}$ 2009.
} 
deployed mobile-WiMAX as their $4 \mathrm{G}$ solution. However, Sprint is evaluating the LTE equipment $^{16}$ for a future transition to LTE.

\section{LTE contracts winnings by vendors}

There are a number of service providers who have committed to LTE as choice of technology for their next generation mobile communication network. However, there are few service providers who have already announced their LTE network contract awarded to various vendors. TeliaSonera has awarded ${ }^{17}$ one of the first LTE contracts to Ericsson and Huawei and is planning to launch the service commercially in 2010 . Verizon has awarded $^{18}$ an LTE contract to Alcatel-Lucent \& Ericsson (radio access network), and Starent Networks (core network). Verizon has announced their plan ${ }^{19}$ of launching a "pre-commercial" LTE service in two cities in the US by the end of 2009 and commercial launch in 2010 with an initial service in 25 to 30 cities in the US. KDDI announced 20

\footnotetext{
${ }^{16}$ Sprint evaluating LTE equipment, http://gigaom.com/2009/03/09/sprint-evaluating-lte-equipment/, last accessed on June $30^{\text {th }} 2009$.

${ }^{17}$ TeliaSonera awards first LTE contract, http://telephonyonline.com/wireless/news/telia-sonera-ltecontract-0115/, last accessed on July $2^{\text {nd }} 2009$.
}

${ }^{18}$ Alcatel-Lucent \& Ericsson win Verizon LTE contract, http://www.itwire.com/content/view/23336/1154/, last accessed on July $2^{\text {nd }} 2009$.

${ }^{19}$ Verizon confirms details of US LTE deployment, http://www.networkworld.com/news/2009/021809. mwc-verizon.html, last accessed on July $2^{\text {nd }} 2009$.

${ }^{20}$ Japan's KDDI selects LTE core as next-generation mobile broadband solution from Hitachi and Nortel, http:/www2.nortel.com/go/news detail.jsp?cat_id=-8055\&locale=en-US\&oid=100250010, last accessed on July $2^{\text {nd }}, 2009$. 
their LTE core network contract award as well. Early adoption of LTE by service providers who have existing CDMA networks (i.e. Verizon and KDDI) is a sign of success towards convergence to LTE.

\section{Motivation of stakeholders to converge and adopt LTE}

The primary motivation of various stakeholders is to have a network that provides high throughput in terms of data rates, is cost effective (i.e. self organizing network that lowers the operational expenditure requirements), and utilizes the spectrum efficiently. The LTE technology realizes the primary motivation of stakeholders by having these requirements as core in the standard. This type of network opens up the avenue to provide new and innovative services like mobile high definition television broadcast, video blogging, real-time gaming etc. Various types of stakeholders have another motivation to create a global ecosystem of devices and services around LTE technology. Table 4.9 provides the most common motivations of stakeholders.

Table 4.9: Motivations of stakeholders to adopt LTE

\begin{tabular}{|l|l|l|l|}
\hline Stakeholder & \multicolumn{1}{|c|}{ Type } & \multicolumn{1}{|c|}{ Motivation(s) } & \multicolumn{1}{c|}{ Reference } \\
\hline Bell & Service & Cost effective and efficient NW & http://www.bce.ca/en/news/releases/bm/ \\
& Provider & $\begin{array}{l}\text { Better services } \\
\text { Company ambitions } \\
\end{array}$ & Be part of global Ecosystem - \\
& & convergence, roaming revenue, \\
& & Availability of popular devices & \\
& &
\end{tabular}




\begin{tabular}{|c|c|c|c|}
\hline Telus & $\begin{array}{l}\text { Service } \\
\text { Provider }\end{array}$ & $\begin{array}{l}\text { Cost effective and efficient NW } \\
\text { Better services and fast NW } \\
\text { Company ambitions } \\
\text { Be part of global Ecosystem - } \\
\text { convergence, roaming revenue, } \\
\text { Availability of popular devices }\end{array}$ & $\begin{array}{l}\text { http://about.telus.com/cgi- } \\
\text { bin/media_news_viewer.cgi?news_id=9 } \\
\text { 56\&mode=2\&news_year=2008 }\end{array}$ \\
\hline Rogers & $\begin{array}{l}\text { Service } \\
\text { Provider }\end{array}$ & $\begin{array}{l}\text { Cost effective and efficient NW } \\
\text { Better services and fast NW } \\
\text { Service streamlining i.e. Provide } \\
\text { internet service over LTE }\end{array}$ & $\begin{array}{l}\text { http://www.boygeniusreport.com/2009/0 } \\
\text { 2/19/rogers-lte-launch-details-revealed/ }\end{array}$ \\
\hline Verizon & $\begin{array}{l}\text { Service } \\
\text { Provider }\end{array}$ & $\begin{array}{l}\text { Cost effective and efficient NW } \\
\text { Better services and fast NW } \\
\text { Time to Market } \\
\text { Be part of global Ecosystem - } \\
\text { convergence, roaming revenue }\end{array}$ & $\begin{array}{l}\text { http://news.vzw.com/news/2009/02/pr20 } \\
\text { 09-02-18.html }\end{array}$ \\
\hline AT\&T & $\begin{array}{l}\text { Service } \\
\text { Provider }\end{array}$ & $\begin{array}{l}\text { Cost effective and efficient NW } \\
\text { Better services and fast NW } \\
\text { Be part of global Ecosystem - } \\
\text { convergence, roaming revenue }\end{array}$ & $\begin{array}{l}\text { http://www.cn- } \\
\text { c1 14.net/576/a410293.html } \\
\text { http://www.intomobile.com/2008/04/05/ } \\
\text { att-4g-lte-network-in-2012.html }\end{array}$ \\
\hline Alltel & $\begin{array}{l}\text { Service } \\
\text { Provider }\end{array}$ & $\begin{array}{l}\text { Cost effective and efficient NW } \\
\text { Better services and fast NW } \\
\text { Time to Market } \\
\text { Be part of global Ecosystem - } \\
\text { convergence, roaming revenue }\end{array}$ & $\begin{array}{l}\text { http://www.multicellphone.com/alltel- } \\
\text { for-4g-lte-network/ }\end{array}$ \\
\hline Sprint & $\begin{array}{l}\text { Service } \\
\text { Provider }\end{array}$ & $\begin{array}{l}\text { Be part of global Ecosystem - } \\
\text { convergence, roaming revenue }\end{array}$ & $\begin{array}{l}\text { http://gigaom.com/2009/03/09/sprint- } \\
\text { evaluating-lte-equipment/ }\end{array}$ \\
\hline $\begin{array}{l}\text { T-mobile } \\
\text { US }\end{array}$ & $\begin{array}{l}\text { Service } \\
\text { Provider }\end{array}$ & $\begin{array}{l}\text { Cost effective and efficient NW } \\
\text { Natural roadmap }\end{array}$ & $\begin{array}{l}\text { http://www.telegeography.com/cu/article } \\
\text {.php?article_id=25979 }\end{array}$ \\
\hline Vodafone & $\begin{array}{l}\text { Service } \\
\text { Provider }\end{array}$ & $\begin{array}{l}\text { Fast, cost effective and efficient } \\
\text { NW } \\
\text { Natural roadmap }\end{array}$ & $\begin{array}{l}\text { http://www.unstrung.com/document.asp } \\
\text { ?doc_id=171477 }\end{array}$ \\
\hline T-mobile & $\begin{array}{l}\text { Service } \\
\text { Provider }\end{array}$ & $\begin{array}{l}\text { Fast, cost effective and efficient } \\
\text { NW } \\
\text { Natural roadmap }\end{array}$ & $\begin{array}{l}\text { http://www.unstrung.com/document.asp } \\
\text { ?doc_id=172272 }\end{array}$ \\
\hline
\end{tabular}




\begin{tabular}{|c|c|c|c|}
\hline & & Technological leadership & \\
\hline $\begin{array}{l}\text { Telia- } \\
\text { Sonera }\end{array}$ & $\begin{array}{l}\text { Service } \\
\text { Provider }\end{array}$ & $\begin{array}{l}\text { Better services and fast NW } \\
\text { Time to Market }\end{array}$ & $\begin{array}{l}\text { http://telephonyonline.com/wireless/new } \\
\text { s/telia-sonera-lte-contract-0115/ } \\
\text { http://www.umts- } \\
\text { forum.org/content/view/2837/172/ }\end{array}$ \\
\hline KDDI & $\begin{array}{l}\text { Service } \\
\text { Provider }\end{array}$ & $\begin{array}{l}\text { Cost effective and efficient NW } \\
\text { Better services and fast NW }\end{array}$ & $\begin{array}{l}\text { http://www.kddi.com/english/corporate/ } \\
\text { news_release/2008/1203/ }\end{array}$ \\
\hline DoCoMo & $\begin{array}{l}\text { Service } \\
\text { Provider }\end{array}$ & $\begin{array}{l}\text { Cost effective and efficient NW } \\
\text { Better services and fast NW } \\
\text { Time to Market }\end{array}$ & $\begin{array}{l}\text { http://www.nttdocomo.com/technologies } \\
\text { /future/super/index.html } \\
\text { http://www.nttdocomo.com/pr/2008/001 } \\
\text { 390.html }\end{array}$ \\
\hline $\begin{array}{l}\text { Nokia- } \\
\text { Siemens- } \\
\text { Networks }\end{array}$ & $\begin{array}{l}\text { NW } \\
\text { Vendor }\end{array}$ & $\begin{array}{l}\text { Cost effective and efficient NW, } \\
\text { Technological innovation } \\
\text { Better services and fast NW } \\
\text { Win new markets i.e. From } \\
\text { CDMA to LTE } \\
\text { Be part of global Ecosystem - } \\
\text { convergence }\end{array}$ & $\begin{array}{l}\text { http://www.nokiasiemensnetworks.com/ } \\
\text { global/Insight/uniteMagazine/Spring+20 } \\
\text { 08/LTE_starts_now.htm?languagecode= } \\
\text { e }\end{array}$ \\
\hline Ericsson & $\begin{array}{l}\text { NW } \\
\text { Vendor }\end{array}$ & $\begin{array}{l}\text { Cost effective and efficient NW, } \\
\text { Technological innovation } \\
\text { Better services and fast NW } \\
\text { Win new markets i.e. From } \\
\text { CDMA to LTE } \\
\text { Be part of global Ecosystem - } \\
\text { convergence }\end{array}$ & $\begin{array}{l}\text { http://www.ericsson.com/ericsson/corpin } \\
\text { fo/publications/review/2008_02/files/5_ } \\
\text { SimpleRNM.pdf }\end{array}$ \\
\hline $\begin{array}{l}\text { Alcatel- } \\
\text { Lucent }\end{array}$ & $\begin{array}{l}\text { NW } \\
\text { Vendor }\end{array}$ & $\begin{array}{l}\text { Cost effective and efficient NW, } \\
\text { Technological innovation } \\
\text { Better services and fast NW } \\
\text { Be part of global Ecosystem - } \\
\text { convergence }\end{array}$ & $\begin{array}{l}\text { http://www.alcatel- } \\
\text { lucent.com/technology/lte/ }\end{array}$ \\
\hline
\end{tabular}




\begin{tabular}{|c|c|c|c|}
\hline Nortel & $\begin{array}{l}\text { NW } \\
\text { Vendor }\end{array}$ & $\begin{array}{l}\text { Cost effective and efficient NW, } \\
\text { Technological innovation } \\
\text { Better services and fast NW } \\
\text { Build IPR } \\
\text { Be part of global Ecosystem - } \\
\text { convergence }\end{array}$ & $\begin{array}{l}\text { http://www.nortel.com/lte } \\
\text { http://www.nortel.com/multimedia/flash/ } \\
\text { demo/index_760_nonav.html?demo=4g }\end{array}$ \\
\hline Hitachi & $\begin{array}{l}\text { NW } \\
\text { Vendor }\end{array}$ & $\begin{array}{l}\text { Fast, cost effective and efficient } \\
\mathrm{NW}, \text { Technological innovation }\end{array}$ & $\begin{array}{l}\text { http://www.kddi.com/english/corporate/ } \\
\text { news_release/2008/1203/ }\end{array}$ \\
\hline Huawei & $\begin{array}{l}\text { NW } \\
\text { Vendor }\end{array}$ & $\begin{array}{l}\text { Cost effective and efficient NW, } \\
\text { Technological innovation } \\
\text { Better services and fast NW } \\
\text { Build IPR }\end{array}$ & $\begin{array}{l}\text { http://www.huawei.com/radio_access_n } \\
\text { etwork/lte.do } \\
\text { http://www.huawei.com/policy/simplere } \\
\text { s.do?id=2852\&type=solution2 }\end{array}$ \\
\hline Starent & $\begin{array}{l}\text { NW } \\
\text { Vendor }\end{array}$ & $\begin{array}{l}\text { Be part of global Ecosystem - } \\
\text { convergence }\end{array}$ & $\begin{array}{l}\text { http://www.starentnetworks.com/en/pres } \\
\text { s.php?id=106 }\end{array}$ \\
\hline NEC & $\begin{array}{l}\text { NW } \\
\text { Vendor }\end{array}$ & $\begin{array}{l}\text { Cost effective and efficient NW } \\
\text { Better services and fast NW }\end{array}$ & $\begin{array}{l}\text { http://www.nec.com/global/solutions/ns } \\
\text { p/lte/ }\end{array}$ \\
\hline Motorola & $\begin{array}{l}\text { NW } \\
\text { Vendor }\end{array}$ & $\begin{array}{l}\text { Cost effective and efficient NW } \\
\text { Better services and fast NW } \\
\text { Win new markets i.e. From } \\
\text { CDMA to LTE } \\
\text { Be part of global Ecosystem - } \\
\text { convergence }\end{array}$ & $\begin{array}{l}\text { http://business.motorola.com/experience } \\
\text { Ite/home.html } \\
\text { http://www.motorola.com/business/v/ind } \\
\text { ex.jsp?vgnextoid=1cb5d610cfal7110Vg } \\
\text { nVCM1000008406b00aRCRD }\end{array}$ \\
\hline Nokia & $\begin{array}{l}\text { UE } \\
\text { Vendor }\end{array}$ & $\begin{array}{l}\text { New revenue stream } \\
\text { Be part of global ecosystem - } \\
\text { convergence }\end{array}$ & $\begin{array}{l}\text { http://gigaom.com } / 2009 / 03 / 04 / \text { nokia- } \\
\text { plans-lte-devices-for-2010/ }\end{array}$ \\
\hline RIM & $\begin{array}{l}\text { UE } \\
\text { Vendor }\end{array}$ & New revenue stream & $\begin{array}{l}\text { http://www.boygeniusreport.com/2008/1 } \\
\text { 1/17/rim-working-on-lte-blackberry-for- } \\
\text { release-when-lte-is-deployed/ }\end{array}$ \\
\hline
\end{tabular}




\begin{tabular}{|c|c|c|c|}
\hline LG & $\begin{array}{l}\text { UE } \\
\text { Vendor }\end{array}$ & $\begin{array}{l}\text { Build IPR } \\
\text { New Revenue Stream } \\
\text { Be part of global Ecosystem - } \\
\text { convergence }\end{array}$ & $\begin{array}{l}\text { http://www.physorg.com/news } 14805679 \\
\text { 2.html }\end{array}$ \\
\hline Apple & $\begin{array}{l}\text { UE } \\
\text { Vendor }\end{array}$ & New revenue stream & $\begin{array}{l}\text { https://www.glgroup.com/News/Verizon } \\
\text {-and-Apple-Testing-LTE-Revenue- } \\
\text { Potential-38099.html } \\
\text { http://gigaom.com/2009/04/26/apple-to- } \\
\text { verizon-can-i-hear-lte-now/ }\end{array}$ \\
\hline $\begin{array}{l}\text { Sony } \\
\text { Ericsson }\end{array}$ & $\begin{array}{l}\text { UE } \\
\text { Vendor }\end{array}$ & $\begin{array}{l}\text { Build IPR } \\
\text { New Revenue Stream } \\
\text { Be part of global Ecosystem - } \\
\text { convergence }\end{array}$ & $\begin{array}{l}\text { http://www.ericsson.com/ericsson/press/ } \\
\text { releases/20080401-1205240.shtml }\end{array}$ \\
\hline Samsung & $\begin{array}{l}\text { UE } \\
\text { Vendor }\end{array}$ & $\begin{array}{l}\text { Be part of global Ecosystem - } \\
\text { convergence }\end{array}$ & $\begin{array}{l}\text { http://www.samsung.com/global/busines } \\
\text { s/telecommunication/newsView.do?b2b } \\
\text { _bbs_msg_id=170 }\end{array}$ \\
\hline Qualcomm & Chipset & $\begin{array}{l}\text { Build IPR } \\
\text { New Revenue Stream } \\
\text { Be part of global Ecosystem - } \\
\text { convergence }\end{array}$ & $\begin{array}{l}\text { http://www.qualcomm.com/news/release } \\
\text { s/2009/090216_Qualcomm_Intros_3G_ } \\
\text { LTE_Integrated_Solution_for_Smartpho } \\
\text { nes.html }\end{array}$ \\
\hline NXP & Chipset & $\begin{array}{l}\text { Time to market } \\
\text { Be part of global ecosystem - } \\
\text { convergence }\end{array}$ & $\begin{array}{l}\text { http://www.3g.co.uk/PR/Jan2008/5693.h } \\
\mathrm{tm}\end{array}$ \\
\hline ST-Ericsson & Chipset & $\begin{array}{l}\text { Be part of global Ecosystem - } \\
\text { convergence }\end{array}$ & $\begin{array}{l}\text { http://www.stericsson.com/platforms/lte } \\
\text { _m700.jsp }\end{array}$ \\
\hline Anritsu & $\begin{array}{l}\text { Test } \\
\text { Equip- } \\
\text { ment }\end{array}$ & $\begin{array}{l}\text { Emulation \& simulation of } \\
\text { standard } \\
\text { Time to market } \\
\text { Early revenue capture }\end{array}$ & $\begin{array}{l}\text { http://www.us.anritsu.com/news/2009/A } \\
\text { nritsu-LTE-Test-Leadership-Position- } \\
\text { on-Display-at-CTIA-WIRELESS-2009- } \\
\text { _ARNid892.aspx }\end{array}$ \\
\hline Agilent & $\begin{array}{l}\text { Test } \\
\text { Equip- } \\
\text { ment }\end{array}$ & $\begin{array}{l}\text { Emulation \& simulation of } \\
\text { standard } \\
\text { Time to market }\end{array}$ & $\begin{array}{l}\text { http://www.home.agilent.com/agilent/ap } \\
\text { plication.jspx?cc=US\&lc=eng\&nid=- } \\
34867.0 .00\end{array}$ \\
\hline
\end{tabular}




\begin{tabular}{|l|l|l|l|}
\hline & & Early revenue capture & \\
\hline $\begin{array}{l}\text { Rohde \& } \\
\text { Schwarz }\end{array}$ & $\begin{array}{l}\text { Test } \\
\text { Equip- } \\
\text { ment }\end{array}$ & $\begin{array}{l}\text { Emulation \& simulation of } \\
\text { standard } \\
\text { Time to market } \\
\text { Early revenue capture }\end{array}$ & $\begin{array}{l}\text { http:/www2.rohde- } \\
\text { schwarz.com/en/technologies/cellular_st } \\
\text { andards/LTE/highlights/ }\end{array}$ \\
\hline Tektronix & $\begin{array}{l}\text { Test } \\
\text { Equip- } \\
\text { ment }\end{array}$ & $\begin{array}{l}\text { Emulation \& simulation of } \\
\text { standard } \\
\text { Time to market } \\
\text { Early revenue capture }\end{array}$ & $\begin{array}{l}\text { http:/www.tektronixcommunications.co } \\
\text { m/modules/communications/index.php?c } \\
\text { ommand=defaultPage\&operation=displa } \\
\text { yDataSheet\&catid=2300\&id=517 }\end{array}$ \\
\hline
\end{tabular}

Key motivations for the service provider community are:

- Cost effective and efficient network

- Better services and fast network

- Time to Market

- Be part of global Ecosystem - convergence, roaming revenue

- Availability of popular devices

Key motivations for the vendor community are:

- Technological innovation

- Better services and fast network

- Build IPR

- New revenue stream

- Be part of global Ecosystem - convergence 


\subsubsection{Chronological timeline of events in the 'LSTI activities' layer}

Events in this layer involve the various trial activities undertaken by the LSTI initiative which is a collaborative effort of various types of stakeholders that includes service providers, network equipment vendors, User Equipment (UE) and chipset vendors. Figure 4.5 depicts the events in a chronological order and Table 4.10 provides a description of the events.

Figure 4.5: Chronological timeline of events in the LSTI activities layer

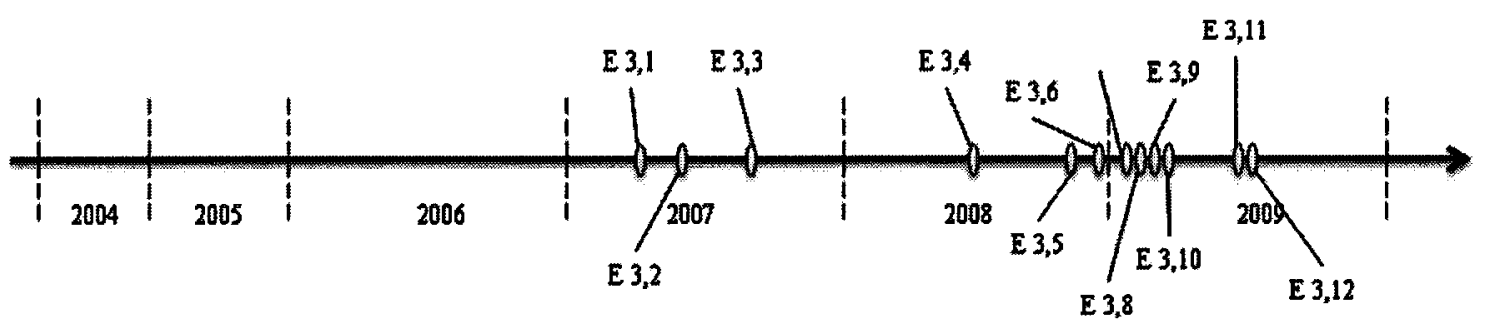

Table 4.10: Description of the events in the LSTI activities layer

\begin{tabular}{|c|c|c|c|}
\hline ID & Date & Event & Reference \\
\hline $\begin{array}{l}\mathrm{E} \\
3,1\end{array}$ & 2007 Q1 & Beginning of Proof-of-Concept trials (PoC) & $\begin{array}{l}\text { http://www.Istiforum.com/abou } \\
\text { t/lsti_organisation_6.html }\end{array}$ \\
\hline $\begin{array}{l}\mathrm{E} \\
3,2\end{array}$ & $\begin{array}{l}2007 \\
\text { May }\end{array}$ & $\begin{array}{l}\text { LSTI inception - LSTI Initiative launched in } \\
\text { May } 2007 \text { by leading telecommunications } \\
\text { companies }\end{array}$ & $\begin{array}{l}\text { http://www.Istiforum.com/medi } \\
\text { a/news.html?listNum=159 }\end{array}$ \\
\hline $\begin{array}{l}\mathrm{E} \\
3,3\end{array}$ & $2007 \mathrm{Q} 3$ & Beginning of interoperability trials (IOT) & $\begin{array}{l}\text { http://www.lstiforum.com/abou } \\
\text { t/lsti_organisation_6.html }\end{array}$ \\
\hline $\begin{array}{l}\mathrm{E} \\
3,4\end{array}$ & $\begin{array}{l}2008 \\
\text { Jun. } 25\end{array}$ & $\begin{array}{l}\text { Various LSTI members presented their wireless } \\
\text { solutions at the 2nd NGMN Industry Conference } \\
\text { 25th }-27 \text { th June } 2008\end{array}$ & $\begin{array}{l}\text { http://www.lstiforum.com/medi } \\
\text { a/news.html?listNum=159 }\end{array}$ \\
\hline $\begin{array}{l}\mathrm{E} \\
3,5\end{array}$ & $2008 \mathrm{Q} 4$ & Completion of Proof-of-Concept trials & $\begin{array}{l}\text { http://www.lstiforum.com/abou } \\
\text { t/lsti_organisation_6.html }\end{array}$ \\
\hline $\begin{array}{l}\mathrm{E} \\
3,6\end{array}$ & $\begin{array}{l}2008 \\
\text { Nov. } 26\end{array}$ & $\begin{array}{l}\text { LSTI provided updates on various activities and } \\
\text { trials }\end{array}$ & $\begin{array}{l}\text { http://www.lstiforum.org/file/n } \\
\text { ews/LSTI_Update_Nov08_vl.p }\end{array}$ \\
\hline
\end{tabular}




\begin{tabular}{|c|c|c|c|}
\hline & & & $\mathrm{df}$ \\
\hline $\begin{array}{l}\mathrm{E} \\
3,7\end{array}$ & $\begin{array}{l}2009 \\
\text { Feb. } 19\end{array}$ & $\begin{array}{l}\text { LSTI testing demonstrates the mobile broadband } \\
\text { capabilities of LTE under real world conditions. } \\
\text { LSTI test results help operators to form realistic } \\
\text { deployment plans for LTE. }\end{array}$ & $\begin{array}{l}\text { http://www.lstiforum.com/medi } \\
\text { a/press.html?listNum=167 }\end{array}$ \\
\hline $\begin{array}{l}\mathrm{E} \\
3,8\end{array}$ & $\begin{array}{l}2009 \\
\text { Feb. } 25\end{array}$ & $\begin{array}{l}\text { LSTI provided updates on various activities and } \\
\text { trials }\end{array}$ & $\begin{array}{l}\text { http://www.lstiforum.org/file/n } \\
\text { ews/Latest_LSTI_Results_Feb0 } \\
\text { 9_v1.pdf }\end{array}$ \\
\hline $\begin{array}{l}\mathrm{E} \\
3,9\end{array}$ & 2009 Q1 & Beginning of friendly customer trials & $\begin{array}{l}\text { http://www.lstiforum.com/abou } \\
\text { t/lsti_organisation_6.html }\end{array}$ \\
\hline $\begin{array}{l}\text { E } \\
3,10\end{array}$ & 2009 Q1 & $\begin{array}{l}\text { LSTI plans to begin cross-vendor interoperability } \\
\text { testing in } 2009 \text {, on the basis of } 3 \mathrm{GPP} \\
\text { specifications which are planned for closure in } \\
\text { the fourth quarter of } 2008 \text {. }\end{array}$ & $\begin{array}{l}\text { http://www.lstiforum.com/medi } \\
\text { a/news.html?listNum }=160\end{array}$ \\
\hline $\begin{array}{l}\mathrm{E} \\
3,11\end{array}$ & $2009 \mathrm{Q} 2$ & Completion of interoperability trials (IOT) & $\begin{array}{l}\text { http://www.lstiforum.com/abou } \\
\text { t/lsti_organisation_6.html }\end{array}$ \\
\hline $\begin{array}{l}\mathrm{E} \\
3,12\end{array}$ & $2009 \mathrm{Q} 2$ & Completion of friendly customer trials & $\begin{array}{l}\text { http://www.Istiforum.com/abou } \\
\text { t/lsti_organisation_6.html }\end{array}$ \\
\hline
\end{tabular}

\section{Number of stakeholder companies}

LSTI members include 26 of the largest vendors in the mobile communication space and 13 major mobile communication service providers. Table 4.11 lists the LSTI member companies. 
Table 4.11: LSTI stakeholder companies ${ }^{21}$

\begin{tabular}{|l|l|}
\hline \multicolumn{1}{|c|}{ Type of Company } & \multicolumn{1}{c|}{ Company names } \\
\hline $\begin{array}{l}\text { Vendors (Network } \\
\text { equipment, UE, chipset, test } \\
\text { equipment) }\end{array}$ & $\begin{array}{l}\text { Cisco, Setcom, Agilent, Alcatel-lucent, Azimuth, Elektrobit, Ericsson, } \\
\text { Freescale, Fujitsu, Huawei, LG, Motorola, NEC, Nethawk, Nokia, } \\
\text { NokiaSiemensNetworks, Nortel, Panasonic, Qualcomm, Rohde \& } \\
\text { Schwarz, Samsung, Signalion, ST-Ericsson, Starent Networks, Tektronix, } \\
\text { ZTE }\end{array}$ \\
\hline Service Providers & $\begin{array}{l}\text { China Mobile, DT Mobile, NTT DoCoMo, eMobile, FranceTelecom } \\
\text { Group, Bouygues Telecom, SFR, SK Telecom, T-Mobile, Telecom Italia, } \\
\text { Telefonica, Turkcell, Vodafone (represents Verizon) }\end{array}$ \\
\hline
\end{tabular}

This collaboration among vendors and service providers has accelerated the availability of commercial and interoperable LTE mobile communication technology. Through various trial activities this collaborative initiative has driven the commercialization of LTE and demonstrated its capabilities in real-world setup.

These trials have stimulated and encouraged early development and implementation of network equipment and UE vendors. Various scenarios (e.g. call setup, call handoffs) were evaluated to increase the service provider confidence in LTE technology and its readiness for a commercial launch in the near future.

\section{Industry type of member stakeholders}

The list of LSTI members (Table 4.11) involves stakeholders from all industries i.e. network equipment vendors, service providers, UE vendors, chipset vendors and test

\footnotetext{
${ }^{21}$ LSTI members, http://www.lstiforum.org/about/lsti_membership.html, last accessed on June $30^{\text {th }} 2009$.
} 
equipment vendors. This initiative has a mandate to develop an open industry

ecosystem ${ }^{22}$ by involving all stakeholders. This ecosystem development effort around LTE technology is to convince service providers and industry analysts to invest into LTE. Another goal is to inform the regulatory bodies to create a favorable environment as LTE has the potential to overcome the digital divide. Interoperability testing is conducted with real end user equipment and with equipment that is close to commercialization. This ensures that end user devices and chipsets are available when LTE services are launched in 2010.

\section{Type of trials undertaken by LSTI members}

LSTI activities are conducted from the standardization phase of LTE to commercial deployment by service providers. LSTI activities started with "Proof-of-Concept" trials to make sure that the technology can be actually deployable in a commercial setup. Subsequent trials include interoperability tests of equipment between major vendors in a pre-commercial environment. Before the commercial rollout, friendly customer trials are also part of the LSTI mandate.

Results $^{23}$ from these trials have been released back to the $3 \mathrm{GPP}$ in order to shape the standardization, improving the quality of commercial LTE products.

\footnotetext{
${ }^{22}$ About LSTI, http://www.lstiforum.org/about/intro.html, last accessed on June $30^{\text {th }} 2009$.

${ }^{23}$ Latest results from the LSTI, Feb 2009, http://www.lstiforum.org/file/news/Latest LSTI Results_Feb09_v1.pdf, last accessed on July $2^{\text {nd }}, 2009$.
} 


\subsubsection{Chronological timeline of events in the 'LTE standard release' layer}

Events in this layer involve the various events in the 3GPP standards release. Figure 4.6 depicts the events in a chronological order and Table 4.12 provides a description of the events.

Figure 4.6: Chronological timeline of events in the LTE standard release layer

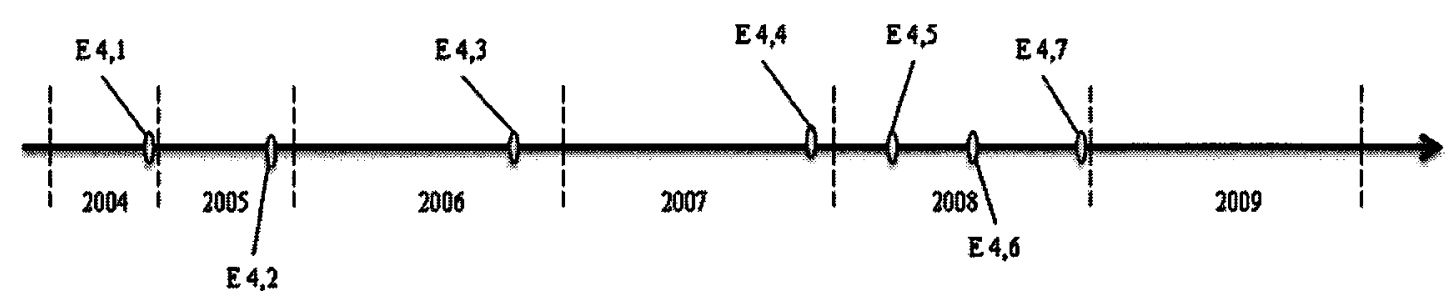

Table 4.12: Description of the events in the LTE standard release layer

\begin{tabular}{|l|l|l|l|}
\hline \multicolumn{1}{|c|}{ ID } & Date & \multicolumn{1}{|c|}{ Event } & \multicolumn{1}{c|}{ Reference } \\
\hline $\begin{array}{l}\text { E } \\
4,1\end{array}$ & $\begin{array}{l}2004 \\
\text { Nov. }\end{array}$ & $\begin{array}{l}\text { 3GPP began a project to define the long-term } \\
\text { evolution of UMTS cellular technology }\end{array}$ & $\begin{array}{l}\text { http://www.dspdesignline.com/ } \\
\text { showArticle.jhtml?articleID=20 } \\
8808450\end{array}$ \\
\hline $\begin{array}{l}\text { E } \\
4,2\end{array}$ & $\begin{array}{l}2005 \\
\text { Sep. }\end{array}$ & $\begin{array}{l}\text { 3GPP Release 7 (HSPA+) standard - stage 1 } \\
\text { freeze }\end{array}$ & http://www.3gpp1.org/Releases \\
\hline E & 2006 & $\begin{array}{l}\text { 3GPP Release 7 (HSPA+) standard - stage 2 } \\
\text { freeze }\end{array}$ & http://www.3gpp1.org/Releases \\
\hline E & 2007 & $\begin{array}{l}\text { 3GPP Release 7 (HSPA+) standard - stage 3 } \\
\text { freeze }\end{array}$ & http://www.3gpp1.org/Releases \\
\hline $\begin{array}{l}\text { E } \\
4,5\end{array}$ & $\begin{array}{l}\text { Dec. } \\
\text { Mar. }\end{array}$ & 3GPP Release 8 (LTE) standard - stage 1 freeze & http://www.3gpp1.org/Releases \\
\hline E & 2008 & 3GPP Release 8 (LTE) standard - stage 2 freeze & http://www.3gpp1.org/Releases \\
4,6 & Jun. & & \\
\hline E & 2008 & 3GPP Release 8 (LTE) standard - stage 3 freeze & http://www.3gpp1.org/Releases \\
4,7 & Dec. & & \\
\hline
\end{tabular}




\section{Acceleration in 3GPP standard release timeline}

$3 \mathrm{GPP}$ standards are typically released in 3 stages $^{24}$ :

- Stage 1 refers to the standard description from a standards' user point of view

- Stage 2 is a logical analysis, breaking the problem down into functional elements and the information flows amongst them

- Stage 3 is the concrete implementation of the protocols between physical elements onto which the functional elements have been mapped

3GPP release 7 (i.e. the HSPA+ standard) completion took more than two years (Stage 1 in September 2005 to Stage 3 in December 2007). However, 3GPP release 8 (i.e. the LTE standard) completion was achieved within one year (Stage 1 in March 2008 to Stage 3 in December 2008). This can be attributed to the collaboration among various stakeholders to test and validate the technology in a real-world setup and feeding the results of such tests back to $3 \mathrm{GPP}$.

\section{Openness analysis of the LTE standard}

Convergence to a newly emerging standard (i.e. not a de-facto standard) cannot be discussed without a discussion of the nature of its openness. The LTE standard openness analysis was based on standard openness literature (Tiemann, 2006; Krechmer, 2006; West, 2007).

\footnotetext{
${ }^{24}$ 3GPP releases, http://www.3gppl.org/Releases, last accessed on July $2^{\text {nd }}, 2009$.
} 
Tiemann's (2006) defines the degree of openness of open standards in terms of the availability of: i) an open source interoperability system, ii) an open source implementation and, iii) a reference implementation that is open source. The LTE standard is very complex and has many specifications. Therefore Tiemann's definition of openness does not fit the broader nature of the LTE standard.

Krechmer (2006) provides another way to define standard openness by defining the requirements that make a standard open. The LTE standard openness analysis provided here is based on these requirements. $3 \mathrm{GPP}$ working procedures ${ }^{25}$ were evaluated to understand the workings of standards development and the resulting LTE standard was evaluated against the requirements for open standards. Table 4.13 lists Krechmer's (2006) requirements and its applicability to LTE standard.

${ }^{25}$ 3GPP Working procedures, http://www.3gppl.org/working-procedures, last accessed on July $10^{\text {th }}, 2009$. 
Table 4.13: Openness analysis of LTE standard

\begin{tabular}{|c|c|c|}
\hline $\begin{array}{l}\text { Krechmer's (2006) } \\
\text { requirements }\end{array}$ & 3GPP LTE's evaluation on the openness requirements & $\begin{array}{l}\text { LTE meets } \\
\text { requirement }\end{array}$ \\
\hline 1. Open meeting & $\begin{array}{l}\text { Participation is open in various technical specification } \\
\text { groups (TSG) and working groups (WG) to all members }\end{array}$ & YES \\
\hline 2. Consensus & $\begin{array}{l}\text { 3GPP's project co-ordination group (PCG) and technical } \\
\text { specification groups (TSG) endeavor to reach consensus on } \\
\text { all issues }\end{array}$ & YES \\
\hline 3. Due Process & $\begin{array}{l}\text { 3GPP's PCG, TSG and WG have mandate to handle appeal } \\
\text { process from individual members }\end{array}$ & YES \\
\hline 4. Open IPR & $\begin{array}{l}\text { Members are required to declare their IPRs that are essential } \\
\text { and grant licenses on fair terms, reasonable terms and } \\
\text { conditions and on a non-discriminatory basis }\end{array}$ & NO \\
\hline 5. One World & 3GPP standards are applicable worldwide & YES \\
\hline 6. Open Change & $\begin{array}{l}\text { All changes and proposals are discussed in TSG and WG and } \\
\text { become enforced after consensus }\end{array}$ & YES \\
\hline 7. Open Documents & $\begin{array}{l}\text { 3GPP specifications and reports are available without any } \\
\text { charges to all }\end{array}$ & YES \\
\hline 8. Open Interface & $\begin{array}{l}\text { Specifies and sets open interfaces for various components of } \\
\text { a wireless system }\end{array}$ & YES \\
\hline 9. Open Access & $\begin{array}{l}\text { Interoperability/accessibility/safety aspects are handled in } \\
\text { the specs \& reports }\end{array}$ & YES \\
\hline 10. On-going Support & $\begin{array}{l}\text { 3GPP standards are evolving continuously release over } \\
\text { release }\end{array}$ & YES \\
\hline
\end{tabular}

West (2007) argues that generally standards are not fully open or proprietary. Intellectual property and patents of contributors to a standard impact the openness of the standard. The fully open IPR requirement of Krechmer (2006) is very difficult to realize. 3GPP members are required to declare their IPRs that are essential and grant licenses on fair 
terms and conditions and on a non-discriminatory basis. Based on these observations it can be concluded that 3GPP LTE is considered to be an open standard.

\subsection{Analysis of cross layer linkage of events}

To identify the linkage between events, a chronological timeline including all 4 layers was developed (Figure 4.7).

Figure 4.7: Chronological timeline of all events in the 4 layers

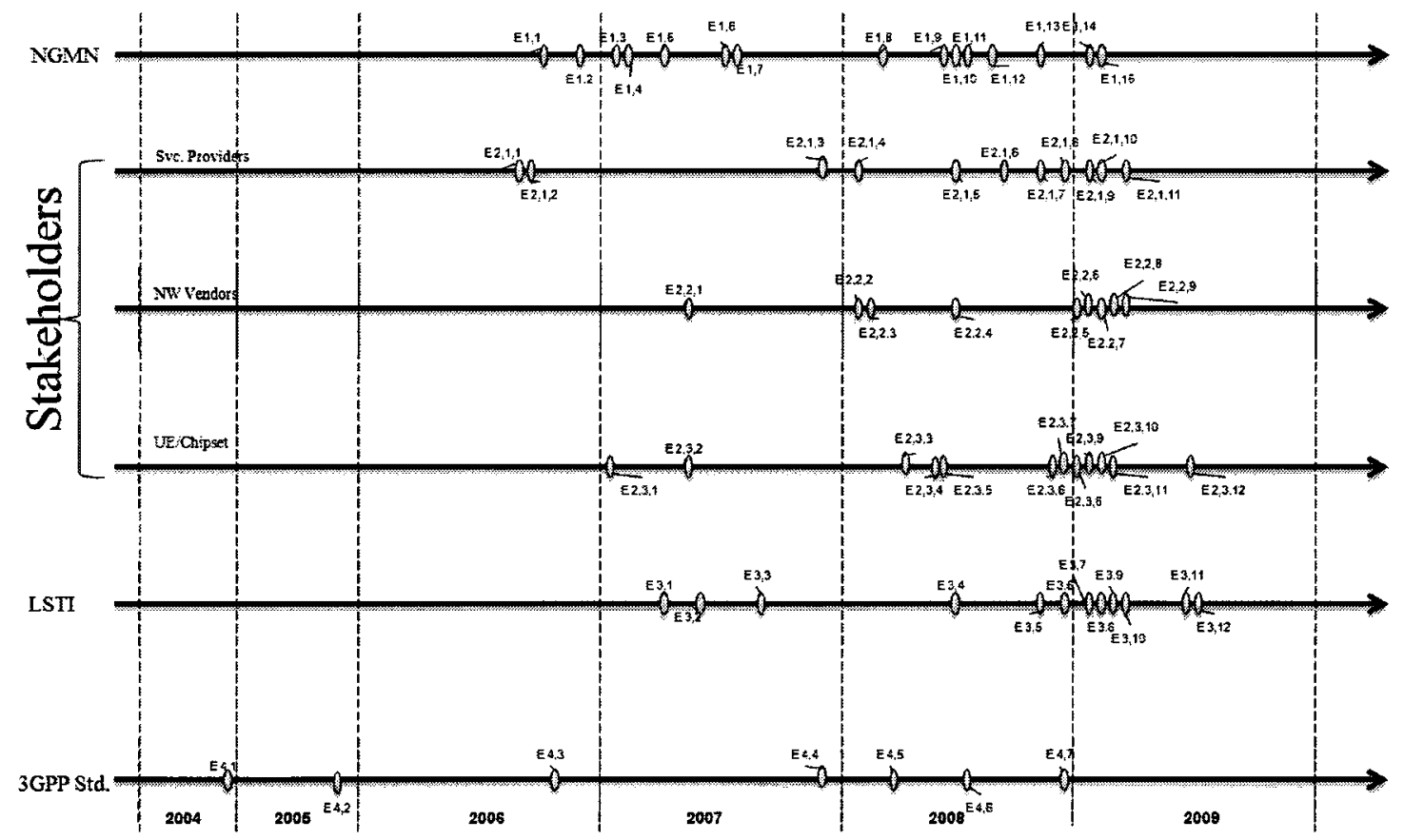

The events in each of the layers presented in Figure 4.7 use the same labels and are presented in the same order as in Figures 4.1 (for layer 1), 4.2 to 4.4 (for layer 2), 4.5 (for 
layer 3) and 4.6 (for layer 4). The description of the events in each layer is given in Tables 4.2 (for layer 1), 4.5 to 4.7 (for layer 2), 4.10 (for layer 3) and 4.12 (for layer 4).

The need for a next generation wireless communication system was expressed in a 3GPP meeting in November 2004. The meeting initiated a series of events in a sequence listed in Table 4.14.

Table 4.14: Related events in longitudinal order

\begin{tabular}{|l|l|l|}
\hline \multicolumn{1}{|c|}{ ID } & \multicolumn{1}{|c|}{ Date } & \multicolumn{1}{c|}{ Event } \\
\hline E 2,1,1 & 2006 Aug. 9 & $\begin{array}{l}\text { Sprint plans to spend \$3bn over the next two years to build a 4G } \\
\text { wireless network using WiMAX technology }\end{array}$ \\
\hline E 1,1 & 2006 Sep. 15 & $\begin{array}{l}\text { Seven of the world's biggest wireless carriers formed NGMN initiative } \\
\text { to provide a coherent view of what the service providers are going to } \\
\text { require in the decade beyond 2010 }\end{array}$ \\
\hline E 3,1 & 2007 Q1 & Beginning of Proof-of-Concept trials (PoC) \\
\hline E 1.5 & 2007 Apr. 17 & $\begin{array}{l}\text { NGMN releases a list of SON (Self organizing networks) use cases for } \\
\text { next generation wireless networks. }\end{array}$ \\
\hline E 3,3 & 2007 Q3 & Beginning of interoperability trials (IOT) \\
\hline E 2,1,3 & 2007 Nov. 29 & Verizon Selects LTE As 4G Wireless Broadband Direction \\
\hline E 2,2,3 & 2008 Feb 16 & $\begin{array}{l}\text { Nokia Siemens Networks showcases LTE interoperability using } \\
\text { Qualcomm technology }\end{array}$ \\
\hline E 1,8 & 2008 Mar. 6 & $\begin{array}{l}\text { NGMN announced that performance of LTE/Mobile WiMAX is getting } \\
\text { closer to NGMN requirements. }\end{array}$ \\
\hline E 4,5 & 2008 Mar. & 3GPP Release 8 (LTE) standard - stage 1 freeze \\
\hline E 2,3,2 & 2008 Apr. & $\begin{array}{l}\text { Ericsson introduces world's first commercial LTE platform (M700) for } \\
\text { mobile devices }\end{array}$ \\
\hline E 1,9 & 2008 Jun. 1 & $\begin{array}{l}\text { NGMN Alliance approves LTE/SAE as its first compliant technology } \\
\text { that broadly meets NGMN recommendations }\end{array}$ \\
\hline E 3,4 & 2008 Jun. 25 & $\begin{array}{l}\text { Various LSTI members presented their wireless solutions at the 2nd } \\
\text { industry conference. }\end{array}$ \\
\hline NGMN Industry Conference 25th - 27th June 2008
\end{tabular}




\begin{tabular}{|c|c|c|}
\hline E 2,1,5 & 2008 Jul. 18 & $\begin{array}{l}\text { Sprint leaves NGMN because the alliance endorsed LTE technology for } \\
4 \mathrm{G} \text { networks }\end{array}$ \\
\hline E 2,1,6 & 2008 Oct. 10 & $\begin{array}{l}\text { Bell and Telus declared a joint plan to move to HSPA in } 2010 \text { and then } \\
\text { to LTE in 2012. Selects NSN and Huawei as vendors. }\end{array}$ \\
\hline E 2,3,6 & 2008 Nov. 13 & $\begin{array}{l}\text { Qualcomm halts UMB project and puts resources into LTE technology } \\
\text { instead as big service-provider customers, such as Verizon Wireless, } \\
\text { have chosen a rival technology called Long Term Evolution for its next- } \\
\text { generation high-speed network }\end{array}$ \\
\hline $\mathbf{E} 3,5$ & $2008 \mathrm{Q} 4$ & Completion of Proof-of-Concept trials \\
\hline $\mathbf{E} 4,7$ & 2008 Dec. & 3GPP Release 8 (LTE) standard - stage 3 freeze \\
\hline $\mathbf{E}$ 3,9 & 2009 Q1 & Beginning of friendly customer trials \\
\hline E 3,10 & $2009 \mathrm{Q} 1$ & $\begin{array}{l}\text { LSTI plans to begin cross-vendor interoperability testing in } 2009 \text {, on the } \\
\text { basis of } 3 \text { GPP specifications which are planned for closure in the fourth } \\
\text { quarter of } 2008 \text {. }\end{array}$ \\
\hline E 2,3,8 & 2009 Jan. 8 & $\begin{array}{l}\text { Nokia ends production of its only WiMAX device and will put its effort } \\
\text { on LTE devices. }\end{array}$ \\
\hline E 1,14 & 2009 Jan. 19 & $\begin{array}{l}\text { NGMN releases final requirements on Self-Optimizing Networks } \\
\text { (SON) }\end{array}$ \\
\hline E 1,15 & 2009 Feb. 12 & NGMN releases requirements for initial terminal device definition \\
\hline E 2,1,10 & 2009 Feb. 18 & $\begin{array}{l}\text { Verizon CTO Dick Lynch announces LTE deployment plans and } \\
\text { announces the vendors for RAN, EPC and IMS }\end{array}$ \\
\hline E 3,7 & 2009 Feb. 19 & $\begin{array}{l}\text { LSTI testing demonstrates the mobile broadband capabilities of LTE } \\
\text { under real world conditions. LSTI test results help operators to form } \\
\text { realistic deployment plans for LTE. }\end{array}$ \\
\hline E 2,1,11 & 2009 Mar. 8 & $\begin{array}{l}\text { Global mobile Suppliers Association (GSA) announced that } 26 \text { network } \\
\text { operators have committed to deploy } 3 \text { GPP LTE systems }\end{array}$ \\
\hline E 3,11 & $2009 \mathrm{Q} 2$ & Completion of interoperability trials (IOT) \\
\hline E 3,12 & $2009 \mathrm{Q} 2$ & Completion of friendly customer trials \\
\hline
\end{tabular}

A visual representation of the development of the above events together with the linkage between them is depicted in Figure 4.8. 
Figure 4.8: Chronological timeline of related events

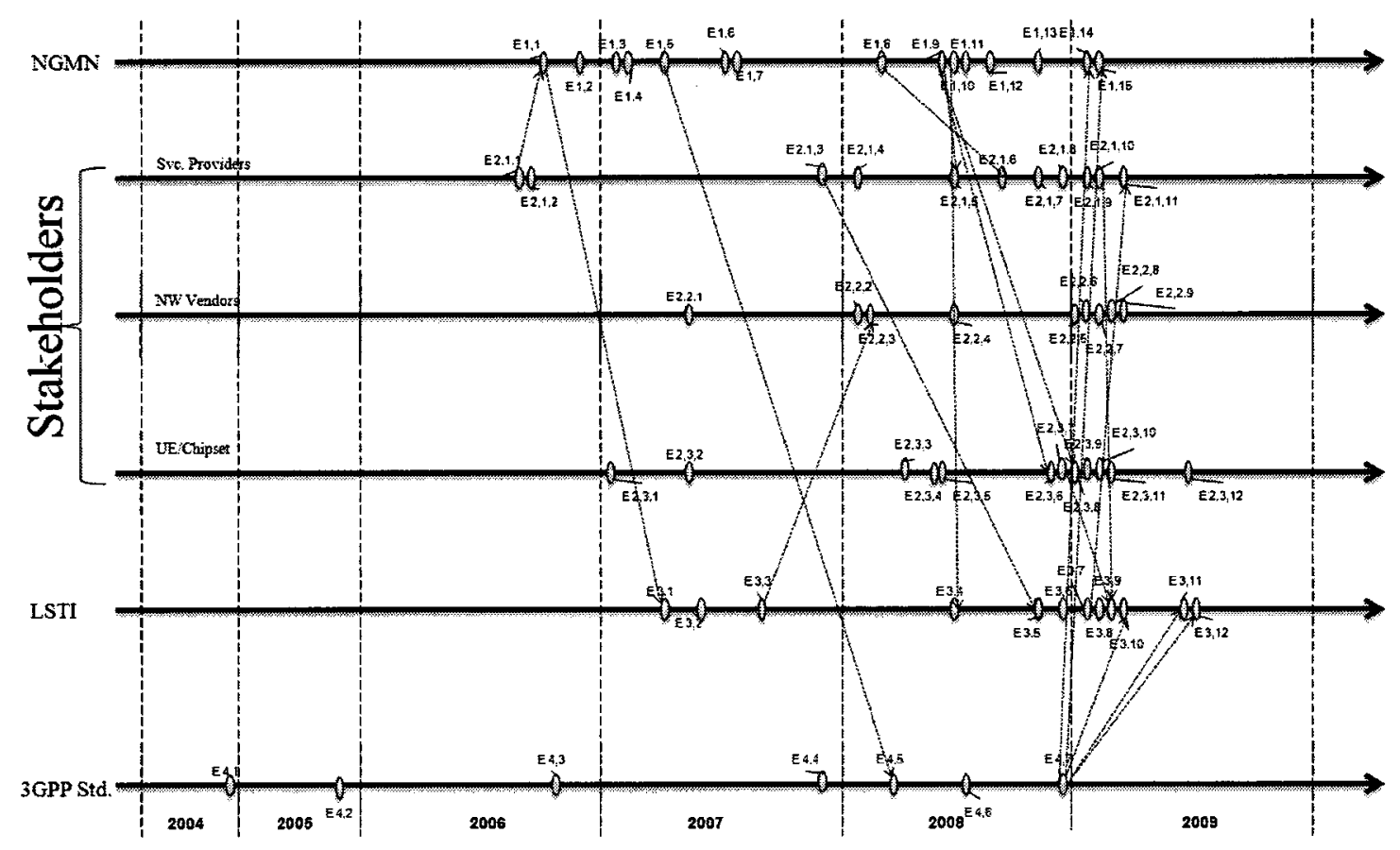

A closer analysis of the threads of events across the layers and observation of phenomenon occurring in the case study was utilized to determine the linkage among the events. Table 4.15 summarizes the identified links. 
Table 4.15: Linkage among the events in various layers

\begin{tabular}{|c|c|}
\hline Link ID & Description \\
\hline $\mathbf{L 1}$ & $\begin{array}{l}\text { Technology trials undertaken by LSTI demonstrated the commercial deployment } \\
\text { readiness of LTE technology and that build the confidence of service providers ( } \\
\text { KDDI, Verizon and TeliaSonera were first to award contracts) }\end{array}$ \\
\hline $\mathbf{L 2}$ & $\begin{array}{l}\text { Service providers put forward their requirements and recommendations for next } \\
\text { generation networks through the NGMN alliance and 3GPP adopted those } \\
\text { requirements in the LTE standard }\end{array}$ \\
\hline$\overline{\mathbf{L 3}}$ & $\begin{array}{l}\text { NGMN approved LTE as the first technology compliant to its requirements and } \\
\text { recommendations and that lead to Sprint leaving the NGMN alliance }\end{array}$ \\
\hline L4 & $\begin{array}{l}\text { Early adoption by Verizon to converge to the LTE standard set the precedence for } \\
\text { other service providers having existing networks that were based on 3GPP2 } \\
\text { technologies (e.g. commitment of adoption by Aircell, MetroPCS, Bell and Telus) }\end{array}$ \\
\hline L5 & $\begin{array}{l}\text { LSTI demonstrated the capabilities of LTE and its readiness for commercial } \\
\text { deployment along with the availability of interoperable UE/chipsets lead to a wider } \\
\text { commitment to adopt the LTE standard }\end{array}$ \\
\hline L6 & $\begin{array}{l}\text { A wider adoption by service providers and momentum in the LTE technology } \\
\text { development lead Qualcomm to halt development of the competing UMB standard }\end{array}$ \\
\hline $\mathbf{L 7}$ & $\begin{array}{l}\text { A wider adoption by service providers and momentum in the LTE technology } \\
\text { development lead Nokia to stop the production of its only WiMAX device }\end{array}$ \\
\hline $\mathbf{L 8}$ & $\begin{array}{l}\text { Interoperability trial plans lead the acceleration in development and availability of } \\
\text { UEs and chipsets }\end{array}$ \\
\hline L9 & $\begin{array}{l}\text { Learning from LSTI trials were used to fine tune the LTE standard and its readiness } \\
\text { for deployment and that lead to acceleration in completion of three stages of } \\
\text { standard development to under a year }\end{array}$ \\
\hline L10 & $\begin{array}{l}\text { Due to open nature of the LTE standard development, IPR were owned by various } \\
\text { stakeholders and that necessitated setting up a IPR sharing framework at low royalty }\end{array}$ \\
\hline
\end{tabular}

\section{Linkages between variables across the layers}

NGMN started with a technology-neutral mandate. Approval of LTE as NGMNcompliant technology impacted the stakeholder layers. Most importantly Sprint, a 
founder of NGMN, decided to leave the alliance as it was planning to adopt WiMAX as its next generation technology. Qualcomm decided to halt the work on UMB and decided to work on LTE technology. Nokia also decided to end the production of its only WiMAX device.

Requirements and recommendations of NGMN members were incorporated in the LTE standard by $3 \mathrm{GPP}$. This can be seen as increasing the confidence of service providers, who are the NGMN members, and catalyzing the LTE contract award by service providers to various vendors.

Various trials conducted under the LSTI initiative drove the 3GPP LTE standard setting activity in an accelerated manner and that was achieved by applying learning from field trials back to standard development. This resulted in a comprehensive and complete standard. Trials also helped the equipment vendors to accelerate their LTE product development and that helped building the service providers' confidence in LTE technology and their commitment to deploy LTE as their next generation networks.

\footnotetext{
Alliance formation by $3 \mathrm{GPP}$ individual members in the form of NGMN helped to set real requirements and recommendations that got adopted by $3 \mathrm{GPP}$ and released as specifications of LTE standard. Another alliance i.e. LSTI, helped to trial the technology in the field setups and drove the completion of standard.
} 


\subsection{Constructs to describe the convergence to the LTE}

Table 4.16 summarizes eight constructs that could be used to describe the convergence to the LTE mobile communication standard. These constructs are drawn from examining the results based on the method described in Section 3.4.7. For each construct, table also shows the dimensions that define it and, for each dimension, its constitutive attributes.

The eight constructs that were identified are: (i) Common technology assets, (ii) Standard evolution life cycle, (iii) Company, (iv) Success definition, (v) Community, (vi) Market and industry drivers, (vii) Standards dynamics, and (viii) Network effects.

Table 4.16: Constructs drawn from the LTE case study

\begin{tabular}{|c|c|c|}
\hline Construct & Dimension & Attributes \\
\hline \multirow[t]{2}{*}{$\begin{array}{l}\text { Common } \\
\text { technology } \\
\text { assets }\end{array}$} & Pedigree & $\begin{array}{l}\text { 3GPP LTE specifications adopted the recommendations made by the } \\
\text { NGMN alliance. Additionally, the trial undertaken by LSTI members } \\
\text { resulted in findings about readiness of standard and technology for field } \\
\text { deployment. These findings were fed back to the standard development for } \\
\text { improvement. } \\
\text { These collaborative efforts by various types of stakeholders helped the } \\
\text { LTE standard to be released at a faster pace than previous standards from } \\
\text { 3GPP. }\end{array}$ \\
\hline & Rights & $\begin{array}{l}\text { An agreement among NGMN members and sponsors allowed them to } \\
\text { access each other's IPR at a very nominal fees. The LTE IPR license } \\
\text { framework encompasses the principle of fair, reasonable and non- } \\
\text { discriminatory (FRAND) terms for essential patents. This allows the single } \\
\text { digit percentage royalty level for LTE handsets. For other devices with } \\
\text { embedded LTE capabilities, a single digit dollar value as royalty is } \\
\text { allowed. }\end{array}$ \\
\hline
\end{tabular}




\begin{tabular}{|c|c|c|}
\hline & & LSTI trial findings and results are accessible to all member companies. \\
\hline \multirow[t]{2}{*}{$\begin{array}{l}\text { Standard } \\
\text { evolution } \\
\text { life cycle }\end{array}$} & $\begin{array}{l}\text { Technology } \\
\text { convergence } \\
\text { phases }\end{array}$ & $\begin{array}{l}\text { Overall convergence towards LTE standardization technology can be } \\
\text { viewed in three phases. } \\
\text { Phase I (Sep. 2006) started with the NGMN alliance formation among } \\
\text { major service providers to formulate their requirements for } 4 \mathrm{G} \text { wireless } \\
\text { communication system and set the stage for various vendors to standardize } \\
\text { the same in LTE specifications. This technology-independent alliance got } \\
\text { the support from major vendors. } \\
\text { Phase } 2 \text { (Jul. 2008) started with NGMN's endorsement for the LTE } \\
\text { technology as compliant to their requirements. That triggered Sprint to } \\
\text { leave NGMN. This phase saw major developments in LTE technology. } \\
\text { Phase } 3 \text { (1Q 2009) started with a radical change in the degree of } \\
\text { commitment by the biggest service providers to LTE acceptance and } \\
\text { adoption. Initial commercial contracts were awarded. }\end{array}$ \\
\hline & $\begin{array}{l}\text { LTE standard } \\
\text { development } \\
\text { stages }\end{array}$ & $\begin{array}{l}\text { The 3GPP LTE standard developed in } 3 \text { stages. } \\
\text { Stage } 1 \text { (Mar. 2008) refers to the standard description from a standards' } \\
\text { user point of view. } \\
\text { Stage } 2 \text { (Jun. 2008) is a logical analysis, breaking the problem down into } \\
\text { functional elements and the information flows amongst them. } \\
\text { Stage } 3 \text { (Dec. 2008) is the concrete implementation of the protocols } \\
\text { between physical elements onto which the functional elements have been } \\
\text { mapped. }\end{array}$ \\
\hline \multirow[t]{2}{*}{ Company } & IPR license & $\begin{array}{l}\text { Unlike CDMA, many vendor companies own patents in various } \\
\text { technologies that form the basis of LTE. Collaboration on various fronts } \\
\text { for technology development (i.e. NGMN and LSTI) allowed them to setup } \\
\text { a framework for licensing each other's patents. The framework allows for } \\
\text { low royalty patent licensing. }\end{array}$ \\
\hline & $\begin{array}{l}\text { Commitment } \\
\text { to standard }\end{array}$ & $\begin{array}{l}\text { Motives for service providers' commitment to adopt the LTE technology } \\
\text { include: (i) lower operational expenditure, (ii) efficient network, (iii) better }\end{array}$ \\
\hline
\end{tabular}




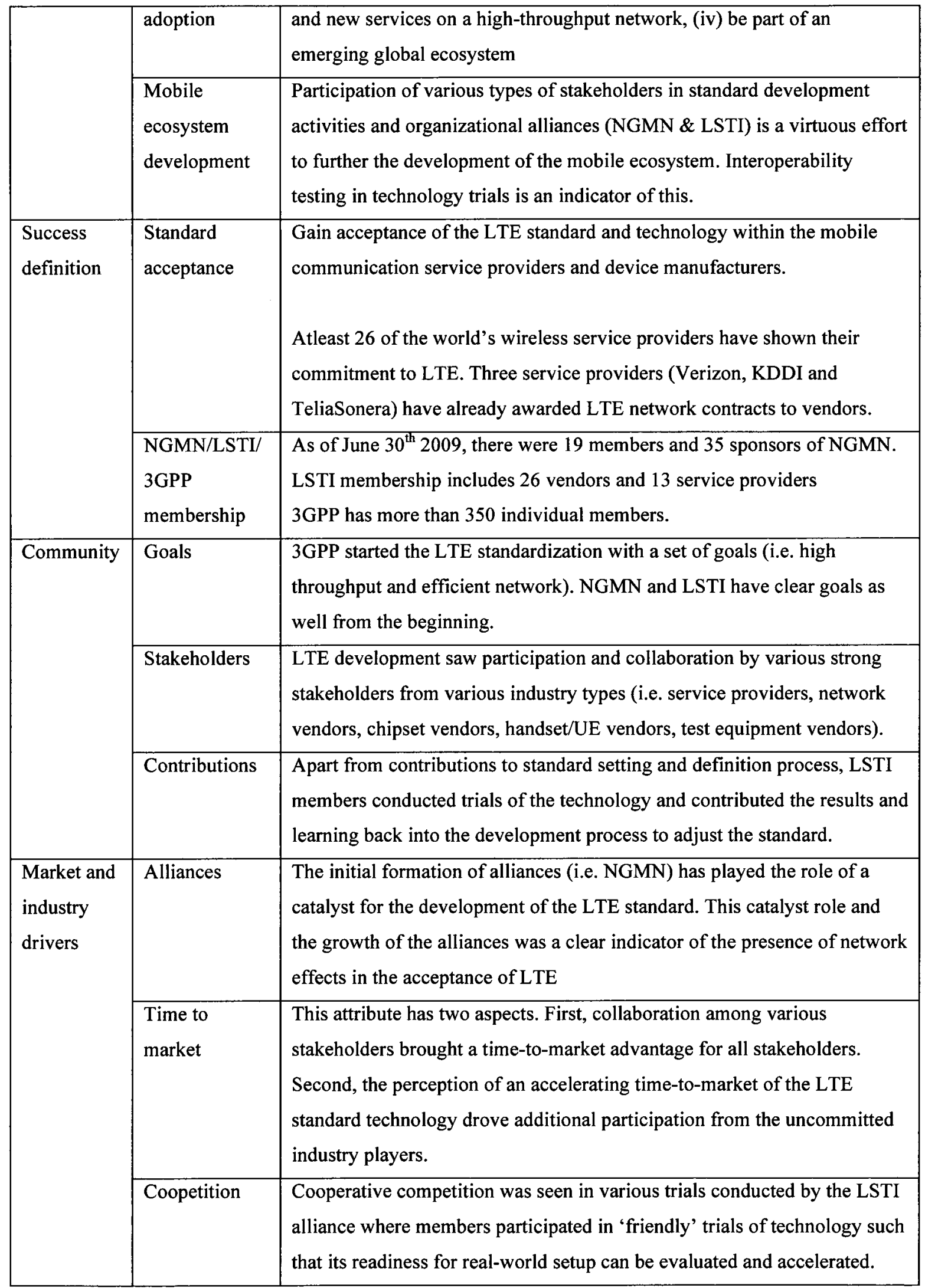




\begin{tabular}{|l|l|l|}
\hline $\begin{array}{l}\text { Standards } \\
\text { dynamics }\end{array}$ & Convergence & $\begin{array}{l}\text { Various service providers who have shown the commitment to LTE have } \\
\text { existing networks that are not 3GPP based (e.g. Verizon, Bell, Telus and } \\
\text { KDDI have existing CDMA networks). }\end{array}$ \\
\cline { 2 - 4 } & $\begin{array}{l}\text { Product } \\
\text { development }\end{array}$ & $\begin{array}{l}\text { Vendors make choices to develop the products based on their technical } \\
\text { roadmap and revenue potential. Various companies pursued the LTE } \\
\text { product development instead of other competing technologies (e.g. } \\
\text { Ericsson decided not to develop WiMAX systems, Qualcomm halted the } \\
\text { work on UMB and instead engaged in LTE product development, Nokia } \\
\text { stopped the production of their only WiMAX user equipment) }\end{array}$ \\
\hline $\begin{array}{l}\text { Network } \\
\text { effects }\end{array}$ & $\begin{array}{l}\text { Direct network } \\
\text { effect }\end{array}$ & $\begin{array}{l}\text { Adoption of LTE technology by major service providers has set the } \\
\text { precedence for other service providers to converge to LTE. }\end{array}$ \\
\cline { 2 - 4 } & $\begin{array}{l}\text { Inter- } \\
\text { operability }\end{array}$ & $\begin{array}{l}\text { Interoperability options in the LTE standard have allowed buildup of an } \\
\text { ecosystem of vendors specializing in specific components of technology. }\end{array}$ \\
\hline
\end{tabular}




\section{Discussions of Results}

The objective of this research was two-fold: i) to provide an answer to the research question: "What are the constructs that could be used to describe the convergence to the LTE mobile communication standard?", and ii) to provide research insights of relevance for both academics and executive managers. This chapter contains the discussion of the results presented in the previous chapter. It is divided into three sections. Section 5.1 provides a discussion on the constructs identified in Chapter 4. Section 5.2 provides a comparison of identified constructs to the constructs that were identified by Xu (2007). Section 5.3 discusses the insights acquired while carrying out this research.

\subsection{Constructs}

The eight constructs that were identified are: (i) Common technology assets, (ii) Standard evolution life cycle, (iii) Company, (iv) Success definition, (v) Community, (vi) Market and industry drivers, (vii) Standards dynamics, and (viii) Network effects.

\subsubsection{Common technology assets}

Two dimensions were observed for the common technology asset construct: (i) Pedigree, and (ii) Rights. The Pedigree dimension refers to the contextual aspects of the LTE standard. The NGMN alliance set the requirements for $4 \mathrm{G}$ wireless communication networks and 3GPP adopted these requirements into the LTE standard (Link L1, see Table 4.15). Additionally, the trials undertaken by LSTI members resulted in knowledge 
about readiness of standard and technology for real-world deployment. These findings were fed back in to the standard development for improvement. These collaborative efforts by various types of stakeholders helped the LTE standard to be released at a faster pace than previous standards from 3GPP (Link L9, see Table 4.15). Figure 5.1 depicts the pedigree dimension by showing the origin of service providers' requirements and trials leading to a field proven standard.

Figure 5.1: The pedigree of the LTE standard development

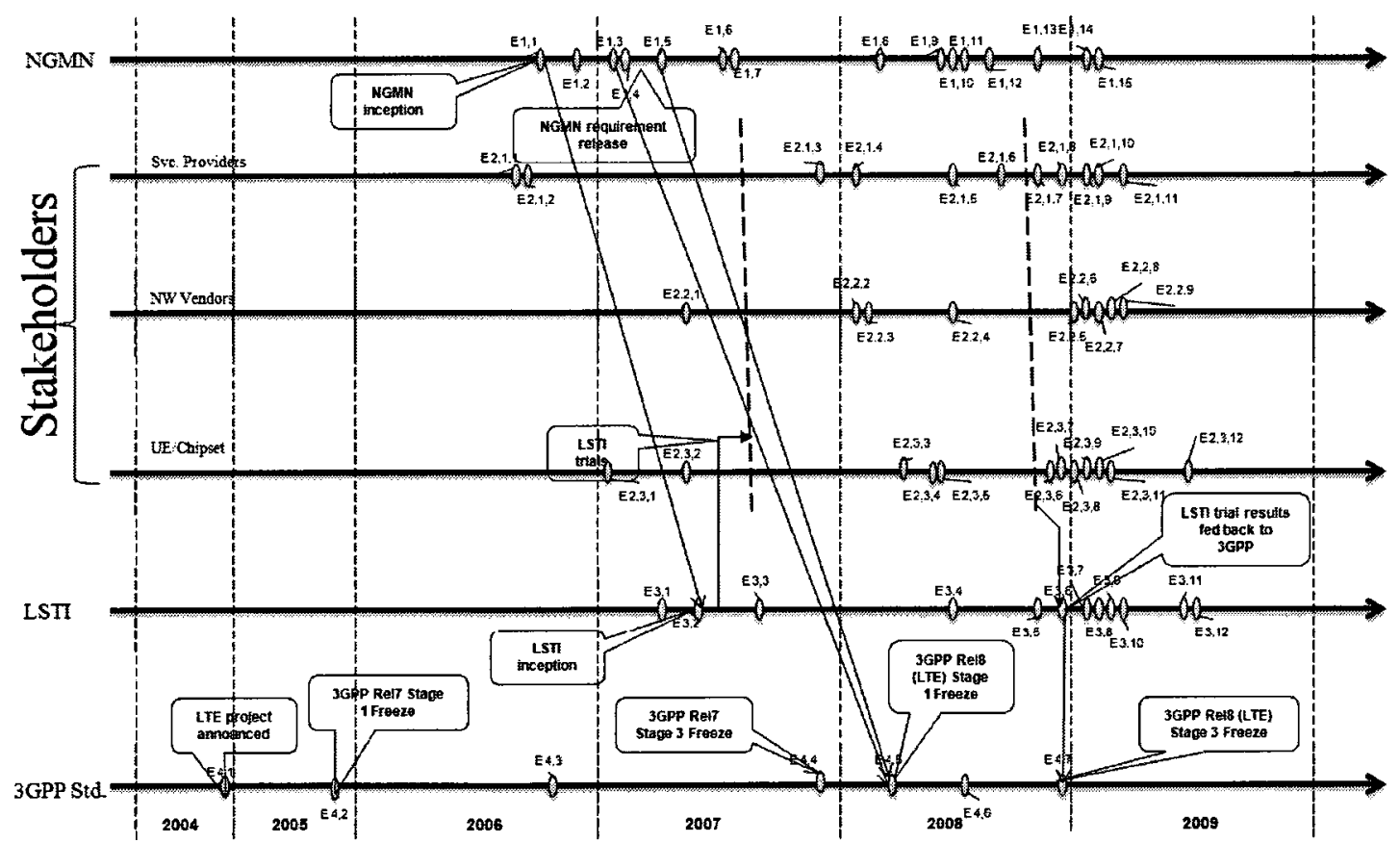

The Rights dimension refers to the rights given to the members of the NGMN alliance. Sponsors of the NGMN alliance account for more than $90 \%$ of the global footprint of mobile network deployment. An agreement among NGMN members and sponsors allowed them to access each other's IPR at a very nominal fees. The LTE IPR license 
framework encompasses the principle of fair, reasonable and non-discriminatory terms for essential patents. This allows the single digit percentage royalty level for LTE handsets. For other devices with embedded LTE capabilities, a single digit dollar value as royalty is allowed (Event E1,7, see Table 4.2). Additionally, LSTI trial findings and results are accessible to all member companies.

\subsubsection{Standard evolution life cycle}

Two dimensions were observed for the standard evolution life cycle construct: (i) Technology convergence phases, and (ii) LTE standard development stages. The Technology convergence phase dimension refers to the various phases that the overall developments towards LTE standardization can be divided into. Three phases were identified.

Although 3GPP started the LTE project in November 2004, not much was reported on activities towards standardization. Phase 1 (Sep. 2006) started with the NGMN alliance formation (Event E 1,1, see Table 4.2) among major service providers to formulate their requirements for a $4 \mathrm{G}$ wireless communication system and set the stage for various vendors to standardize the same in LTE specifications. This technology-independent alliance got support from major vendors. NGMN published the requirements on selforganizing networks, user equipment specifications and spectrum specifications. The formation of the LSTI alliance and LTE PoC trials occurred in the phase as well. Phase 1 ended with the stage 2 freeze of the LTE standard (Event E 4,6, see Table 4.12). 
Phase 2 (Jul. 2008) started with NGMN's endorsement of the LTE technology as compliant to their requirements (Event E 1,9, see Table 4.2). That triggered Sprint to leave NGMN (Link L3, see Table 4.15). This phase saw major developments in LTE technology. Other competing technologies started to see less emphasis on their development and ecosystem creation. In November 2008, Qualcomm halted the UMB project and shifted focus fully on to LTE technology (Link L6, see Table 4.15). In January 2009, Nokia ended the production of its only WiMAX device (Link L7, see Table 4.15). In October 2008, Bell and Telus declared a joint plan to move from CDMA to HSPA in 2010 and then to LTE in 2012. LSTI members continued their focus on performing the technology trials and interoperability trials to refine the technology. Stage 3 freeze of the LTE standard was achieved in this phase. Phase 2 ended with the release of final requirements by the NGMN (Events E 1,14 and E 1,15, see Table 4.2).

Phase 3 (1Q 2009) started with commitments to adopt LTE by the biggest service providers (Events E 2,1,10 and E 2,1,11, see Table 4.5). Service providers started to award the commercial contracts to deploy LTE to the vendors. In February 2009, Verizon announced their LTE deployment plans and selected various vendors for the network. The global mobile suppliers association announced that 26 major service providers have committed to deploy LTE systems (Link L5, see Table 4.15).

Figure 5.2 depicts the three phases described above. 
Figure 5.2: Three phases of LTE project

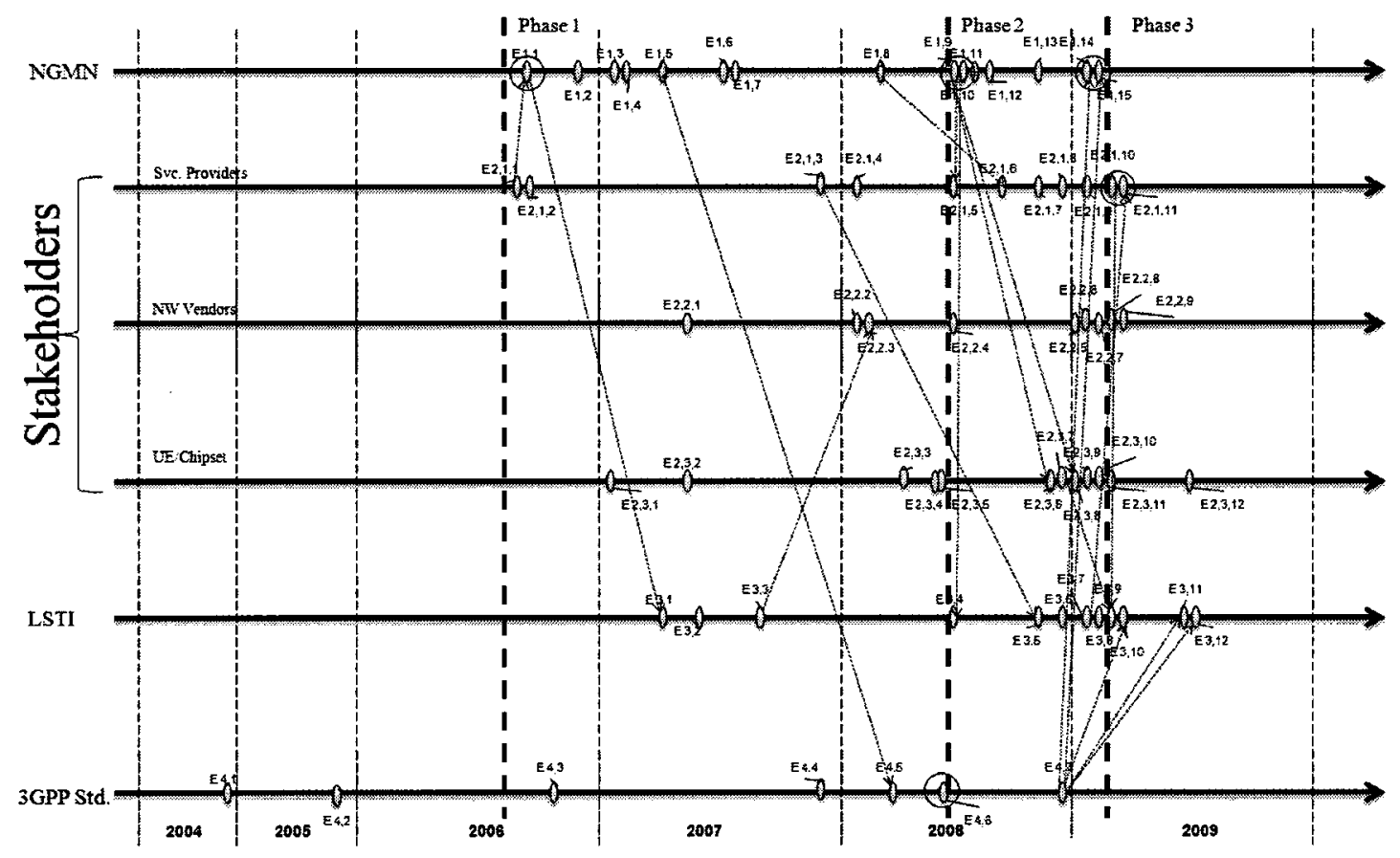

The Standard development stages dimension refers to the release over release acceleration in the 3GPP standard stages. 3GPP release 7 (i.e. HSPA+ standard) completion took more than two years (stage 1 in September 2005 to stage 3 in December 2007). However, 3GPP release 8 (i.e. LTE standard) completion was achieved within one year (stage 1 in March 2008 to stage 3 in December 2008). This can be attributed to the collaboration among various stakeholders to test and validate the technology in realworld setups and making the results of such tests available back to 3GPP (Link L9, see Table 4.15). 


\subsubsection{Company}

The construct Company was comprised of three dimensions: (i) IPR license, (ii) Commitment to standard adoption, and (iii) Mobile ecosystem development. Unlike CDMA, many vendors own patents in various technologies that form the basis of LTE technology. Collaboration on various fronts for technology development (i.e. NGMN and LSTI) allowed them to setup a framework for licensing each other's patents (Event E1,7, see Table 4.2; Link L10, see Table 4.15). The framework allows low royalty patent licensing.

Commitment to standard adoption is the second dimension of the construct. It comprised the motivations for the service providers' commitment to adopt the LTE technology (see Table 4.9). Motivations for LTE adoptions are:

- Lower operational expenditure to operate the network, made possible by the incorporation of self-organizing network capabilities in the LTE standard

- High spectral efficiency and reduced cost of delivery per bit as compared to legacy wireless technologies

- Reduced latency allowing delivery of more responsive user experience. This permits interactive and real-time services such as high quality audio and videoconferencing and multi-player gaming etc.

- Co-existence with legacy systems and standards

- Be part of a global ecosystem 
The third dimension is the Mobile ecosystem development. Participation of various stakeholders in standard development activities and organizational alliances (NGMN \& LSTI) is a virtuous effort to further the LTE mobile ecosystem. The standard development process and technology trials encompassed the industry sectors representing all aspects of the mobile ecosystem. This includes network equipment vendors, chipset vendors, user equipment vendors and test equipment vendors. In addition to these, service providers (who are the customers to various vendors) also participated in standard setting and technology trials (see Table 4.11). Cross-vendor interoperability was an integral part of the technology trials undertaken by LSTI, where radio access networks and core networks from various vendors were tested in a real-world setup with user equipment from different vendors. This ensured the interoperability aspects of the standard, making functional multi-vendor networks a reality and ensuring the availability of interoperable user equipment at the time of commercial deployment of LTE systems (Event E3,3, see Table 4.10).

\subsubsection{Success definition}

The Success definition construct has two dimensions: (i) Standard acceptance, and (ii) NGMN/LSTI/3GPP Membership. Acceptance of the standard is a very important objective of any standard setting organization and alliances that support the process. Participation in LSTI activities by various types of vendors is a clear sign that the vendor community sees major revenue potential in LTE technology and they have engaged in their LTE product development efforts. Service providers have adopted or committed to 
the LTE standard as well. At-least 26 of the world's major wireless service providers have shown their commitment to LTE (Event 2,1,11, see Table 4.5; Link L5, see Table 4.15). Three service providers (Verizon, KDDI and TeliaSonera) have already awarded LTE network contracts to vendors (Event E2,1,8, see Table 4.5; Events E2,2,5 and E2,2,8, see Table 4.6). Success is attributed to the open nature of LTE.

Membership of NGMN, LSTI and 3GPP is the second dimension. As of June 30th 2009, there were 19 members and 35 sponsors of NGMN (see Table 4.3 and Table 4.4). Members of the NGMN alliance represent well over one half of the total mobile subscriber base world-wide. Sponsors of the NGMN alliance account for more than $90 \%$ of the global footprint of mobile network deployment. LSTI membership includes 26 vendors and 13 service providers (see Table 4.11). 3GPP has more than 350 individual members.

\subsubsection{Community}

Three dimensions were observed for the community construct: (i) Goals, (ii) Stakeholders, and (iii) Contributions. The primary goals of the LTE technology were to develop an advanced, all-IP wireless network that utilizes the spectrum and resources efficiently to provide higher throughput. Another goal was to interwork with legacy networks. These goals are very much the essence of the LTE standard and the results of trials undertaken by LSTI alliance are indicative of this. 
The LTE development saw participation and collaboration by various strong stakeholders from various industry types (i.e. service providers, network vendors, chipset vendors, handset/UE vendors, test equipment vendors). These companies brought their experience and innovation to realize the goals of LTE and contributed to standards development and technology trials (Event E2,2,1, see Table 4.6; Event E3,7, see Table 4.10). Various demonstrations of stakeholders' capability were done in various industry tradeshows and forums (Events E2,2,4 and E2,2,6, see Table 4.6; Event E3,4, see Table 4.10).

Contributions and collaboration by various stakeholders is a key dimension in the construct. These companies contributed their resources to the standardization process. In addition, their product development efforts were geared towards successful completion of technology trails conducted by the LSTI alliance. The LSTI alliance also contributed the results and learning back into the LTE development process to fine-tune the standard (Events E3,6 and E3,8, see Table 4.10; Link L9, see Table 4.15).

\subsubsection{Market and industry drivers}

The Market and industry drivers construct was observed with three dimensions: (i) Alliances, (ii) Time to market, and (iii) Coopetition. Formation of alliances by stakeholders represents the first dimension. Various alliances were formed during LTE development. Most notably are NGMN (alliance of service providers and activities sponsored by vendors) and LSTI (an initiative of all types of stakeholders to trial the technology). Alliance formation has been a catalyst in the development of the LTE 
standard. Alliance members also agreed on licensing their IPR at a very nominal royalty (Event E1,7, see Table 4.2; Link L10, see Table 4.15).

Time to market is the second dimension. Quality of the LTE standard and its readiness for real-world deployment at the end of the standardization process was very critical for its success. Various trials (proof-of-concept, interoperability trials etc.) in real-world settings (see Table 4.10) were instrumental to prove the standard and to increase the confidence of early adopters (e.g. Verizon, KDDI and TeliaSonera).

Coopetition $^{26}$ was the third dimension for the construct. Cooperative competition was seen in various trials conducted by the LSTI alliance where members participated in friendly trials of technology (Event E3,9, see Table 4.10) such that its readiness for field deployment can be evaluated.

\subsubsection{Standards dynamics}

Two dimensions were observed for the Standards dynamics construct: (i) Convergence, and (ii) Product development. The Convergence dimension refers to the phenomenon of adopting a single standard among various available technologies (see Table 4.8). Major service providers with non-3GPP based existing networks converged to LTE as their 4G

\footnotetext{
${ }^{26}$ Wikipedia entry on Coopetition, http://en.wikipedia.org/wiki/Coopetition, Last accessed on August $2^{\text {nd }}$ 2009
} 
mobile communication system. For service providers with 3GPP-based existing networks, a choice to migrate from various types of legacy networks (i.e. GSM, WCDMA, HSDPA or HSPA+) to LTE is possible. T-mobile announced that they will skip the HSPA+ upgrade and will move directly to LTE (Event E2,1,7, see Table 4.5).

The Product development dimension refers to the product development choices made by network equipment vendors. Various companies pursued LTE product development instead of other competing technologies (e.g. Ericsson decided not to develop WiMAX systems, Qualcomm halted the work on UMB and instead engaged in LTE product development (Event E2,3,6, see Table 4.7; Link L6, see Table 4.15), Nokia stopped the production of its only WiMAX user equipment (Event E2,3,8, see Table 4.7; Link L7, see Table 4.15)).

\subsubsection{Network effects}

Two dimensions were observed for Network effects construct: (i) Direct network effect, and (ii) Interoperability. The Direct network effect dimension refers to the phenomenon whereby adoption of LTE technology by major service providers is setting the precedence for other service providers to converge to LTE. Verizon's adoption of LTE set the path for commitment of LTE adoption by Aircell and MetroPCS in US (Event E2,1,11, see Table 4.5; Link L4, see Table 4.15). 
The Interoperability dimension refers to the capability of the LTE standard to allow equipment from various vendors in a single network. Interoperability options in the LTE standard have allowed buildup of an ecosystem of vendors specializing in specific components of the technology.

\subsection{Comparison of identified construct to those identified by Xu (2007)}

$\mathrm{Xu}$ (2007) identified the constructs that describe the OpenAccess project. Although this research is similar to $\mathrm{Xu}$ (2007) in terms of adoption of a common standard, the constructs that describe the convergence to LTE are not the same as identified by $\mathrm{Xu}$ (2007) for the OpenAccess project. The main reason for not being able to use the same constructs to describe both phenomena is the difference in nature (both technological and industrial), scope, openness and adoption mechanisms of the two standards (see Table 3.1 for a comparison of the nature and scope of OpenAccess and LTE standards). Table 5.1 provides a comparison of constructs identified in both cases:

Table 5.1: Comparison of constructs describing the LTE and OpenAccess

\begin{tabular}{|c|c|c|}
\hline Construct & Applicability to OpenAccess & Applicability to LTE standard \\
\hline $\begin{array}{l}\text { Common } \\
\text { assets }\end{array}$ & $\begin{array}{l}\text { The OpenAccess standard was an } \\
\text { exemplary case of release of proprietary } \\
\text { technology in the open domain and this } \\
\text { is represented by the Pedigree } \\
\text { dimension. } \\
\text { The Rights dimension represents the }\end{array}$ & $\begin{array}{l}\text { This construct is applicable to the LTE standard } \\
\text { in a similar manner except for the fact that the } \\
\text { LTE standard is a case of de-jure standard. The } \\
\text { Pedigree dimension represents the various } \\
\text { inputs, requirements and recommendation from } \\
\text { stakeholders to standard. }\end{array}$ \\
\hline
\end{tabular}




\begin{tabular}{|c|c|c|}
\hline & $\begin{array}{l}\text { level of accessibility to standard for } \\
\text { members and non-members. }\end{array}$ & $\begin{array}{l}\text { The Rights dimension represents the IPR } \\
\text { license agreement among stakeholders. } \\
\text { Additionally, the accessibility to technology } \\
\text { trial results to members of LSTI is represented } \\
\text { by this dimension. }\end{array}$ \\
\hline $\begin{array}{l}\text { Project life } \\
\text { cycle }\end{array}$ & $\begin{array}{l}\text { Developments in the OpenAccess } \\
\text { project were represented in three phases } \\
\text { by Xu (2007). The project life cycle } \\
\text { construct with phase dimension } \\
\text { describes the phases of the OpenAccess } \\
\text { project. }\end{array}$ & $\begin{array}{l}\text { Due to the collaborative nature of the LTE } \\
\text { standard and its ecosystem development, the } \\
\text { overall actions of various stakeholders is } \\
\text { studied in three phases. The technology } \\
\text { convergence phases dimension of the construct } \\
\text { represents the development phases. } \\
\text { Additionally, the standard setting process of the } \\
\text { LTE standard is divided in three stages by } \\
\text { 3GPP and the standard development stages } \\
\text { dimension of the construct characterizes that. }\end{array}$ \\
\hline Company & $\begin{array}{l}\text { This construct represents the stakeholder } \\
\text { companies in the OpenAccess project. } \\
\text { Five dimensions were used to show the } \\
\text { motivations of Cadence to release their } \\
\text { proprietary standard, adoption of the } \\
\text { OpenAccess standard by companies for } \\
\text { their internal/external products and } \\
\text { competition. }\end{array}$ & $\begin{array}{l}\text { This construct characterizes the broader scope } \\
\text { of stakeholder companies involved in the } \\
\text { development of the LTE technology and } \\
\text { complementary assets. The Mobile ecosystem } \\
\text { development dimension represents the } \\
\text { activities of various types of stakeholders to } \\
\text { further the LTE ecosystem. Commitment to } \\
\text { standard adoption and IPR license agreements } \\
\text { of stakeholder companies are other dimensions } \\
\text { of this construct. }\end{array}$ \\
\hline $\begin{array}{l}\text { Success } \\
\text { definition }\end{array}$ & $\begin{array}{l}\text { This construct represents the adoption of } \\
\text { the OpenAccess standard by various } \\
\text { companies and membership to the } \\
\text { OpenAccess coalition. }\end{array}$ & $\begin{array}{l}\text { This construct characterizes the adoptions of } \\
\text { the standard by service providers and hence is } \\
\text { very similar to its characterization for the } \\
\text { OpenAccess project. Membership of } \\
\text { companies in LTE technology development and } \\
\text { trial activities is another dimension. }\end{array}$ \\
\hline Community & $\begin{array}{l}\text { This construct represents the community } \\
\text { aspects of the OpenAccess standard. } \\
\text { Membership structure and governance } \\
\text { are characterized by member structure } \\
\text { and veto power dimensions of the }\end{array}$ & $\begin{array}{l}\text { This construct characterizes the alliance } \\
\text { formation and collaboration aspects of LTE } \\
\text { development. Goals of the alliances and LTE } \\
\text { standard are represented by the goals } \\
\text { dimension. Various types of stakeholder }\end{array}$ \\
\hline
\end{tabular}




\begin{tabular}{|c|c|c|}
\hline & $\begin{array}{l}\text { construct. Standard download by end } \\
\text { users, maintenance of standard is also } \\
\text { represented in the construct. }\end{array}$ & $\begin{array}{l}\text { companies forming the community to create the } \\
\text { LTE ecosystem is characterized by the } \\
\text { stakeholders dimension. Additionally, the } \\
\text { contributions to standard development and } \\
\text { feedback of trials to standard development as } \\
\text { represented by the contributions dimension. }\end{array}$ \\
\hline $\begin{array}{l}\text { Market and } \\
\text { industry } \\
\text { drivers }\end{array}$ & Not applicable & $\begin{array}{l}\text { This construct characterizes the market and } \\
\text { industry drivers for LTE technology } \\
\text { development. Formation of an alliance by } \\
\text { service providers (i.e. customers of the } \\
\text { standard) and providing requirements for next } \\
\text { generation technologies is represented by the } \\
\text { alliances dimension. } \\
\text { Collaboration among stakeholders to test the } \\
\text { technology in real-world setup and to make } \\
\text { sure the technology is ready for commercial } \\
\text { deployment is characterized by the time to } \\
\text { market dimension. } \\
\text { Collaboration among competitors in various } \\
\text { industry segments (i.e. NW vendors and } \\
\text { handset vendors etc.) to develop and test the } \\
\text { technology is represented by the coopetition } \\
\text { dimension. }\end{array}$ \\
\hline $\begin{array}{l}\text { Standards } \\
\text { dynamics }\end{array}$ & Not applicable & $\begin{array}{l}\text { Convergence by service providers and product } \\
\text { development effort alignment by vendors to the } \\
\text { LTE technology is represented by this } \\
\text { construct. Convergence and product } \\
\text { development are the two representative } \\
\text { dimensions of the construct. }\end{array}$ \\
\hline $\begin{array}{l}\text { Network } \\
\text { effects }\end{array}$ & Not applicable & $\begin{array}{l}\text { This construct characterizes the network effects } \\
\text { aspect of LTE technology. Dimensions are } \\
\text { represented in terms of LTE adoption by } \\
\text { service providers and the standard's capability } \\
\text { of allowing to create complementary assets for } \\
\text { parts of the LTE system. }\end{array}$ \\
\hline
\end{tabular}




\subsection{Insights gained from research}

Nine insights were gained from this research. These insights are:

Collaboration among stakeholders results in a time-to-market advantage in technology standardization and development

Stakeholders' collaboration (Event E3,2, see Table 4.10) on defining the standard and their involvement in the refinement of the standard by learning from real-world testing (Events E3,6, E3,7 and E3,8, see Table 4.10) of products leads to a reduction in overall time to complete the standard. This helps in ecosystem buildup as well and helps the availability of complementary assets upon commercial deployment of technology.

\section{Companies should consider balancing their standard development efforts as} compared to existing legacy product development and maintenance efforts Sufficient effort and resource commitment to new technology development and participation in its standardization process can possibly open up new revenue channels and new market segments. In this process companies can likely develop and own IPR that can help them in the future to earn royalties from its licensing. There are also greater chances of alliance formation that allow the companies to learn from each other while cooperating towards a single goal of technology standardization. This is evident from the activities and developments that happened in both NGMN and LSTI. The companies participating in LSTI learned from the technology trials as the findings of trials were shared among alliance members (Events E3,6 and E3,8, see Table 4.10) and that allowed them to further their LTE development activities. The NGMN members are part of an 
IPR sharing agreement allowing them to license each others' IPR at nominal royalty (Event E1,7, see Table 4.2).

Pre-commercial trials of new technology being standardized in real-world setup build the confidence of customers to converge

Early adopters of a technology can make better decisions based on readiness of the technology for commercial deployment shortly after its standardization. Technology development done in this paradigm helps its adoption by existing market and by new market segments (Event E3,7, see Table 4.10). LTE development was done in the paradigm (Event E1,10, see Table 4.2) and it has seen a deployment commitment (Event E2,1,11, see Table 4.5) by service providers that have 3GPP-based existing networks and more importantly by service providers who have 3GPP2 (i.e. CDMA, 1xDO) based existing networks (Events E2,1,6, E2,1,8 and E2,1,10, see Table 4.5).

\section{Provisions of interoperability with legacy systems help standard adoption}

Roll out of new technology usually happens in phases and covers the intended geographical area over time. Therefore, new technology with interoperability capability (Event E3,3, see Table 4.10) with legacy systems is a driver for its adoption. LTE will allow smooth and seamless service handover in areas where there is no LTE service (i.e. have HSPA, WCDMA, GSM, CDMA or DO coverage). Provisions in LTE to be deployed as overlay network on existing non-3GPP systems (i.e. CDMA or 1xDO) is attractive to such service providers as this will allow them to roll-out their LTE network in several phases without interrupting their existing services. 
The success of technology adoption is driven by the readiness of the technology for

\section{field deployment}

Success of technology is expressed in terms of its adoption by customers in existing and new market segments. For service providers with existing 3GPP-based networks, LTE is the obvious evolution path. However, the service providers that have non-3GPP networks have been converging to LTE as well. First few commercial LTE contracts were awarded by service providers who have existing CDMA/1xDO networks (Events E2,1,6, E2,1,8 and $\mathrm{E} 2,1,10$, see Table 4.5). This can be attributed to the readiness of LTE for commercial deployment soon after closure of the LTE standard (Event E3,9, see Table 4.10).

IPR related to a technology which is standardized in a de-jure manner is not owned by a single stakeholder

Standards setting is done more and more in an open and collaborative manner and therefore the stakeholders involved in defining the standard are the ones who normally own and disclose their IPR. This is contrary to a single stakeholder owning the IPR to complete technology. This can lead to IPR licenses at low royalty among stakeholders (Event E1,7, see Table 4.2). LTE technology IPR is owned by various companies involved in the technology development and their collaboration via the NGMN and LSTI alliances enabled them to agree on low royalty for IPR licenses to each other. This is unlike CDMA technology where IPRs were mostly owned by a single company (i.e. Qualcomm). 


\section{"Coopetition" among stakeholders accelerates technology development and nourishes network effects and acceptance}

Cooperative competition (i.e. coopetition) is a good way to collaborate during technology development (Event E2,2,1, see Table 4.6). This was seen in the LTE development where various vendors shared their resources to perform the technology trials and achieved refinement of the technology. This brings a major cost advantage in technology development as compared to individual companies engaging in technology development on their own. However, coopetition could also result in a standard that is of not utmost technological quality due to the compromises needed to accommodate all the stakeholders.

Value co-creation between stakeholders in standards development helps its broader adoption

A technology solving real customer problems has better chances of getting adopted widely. Value co-creation aspects were seen in the LTE standards development where service providers enlisted their requirements and recommendation (administered through the NGMN alliance) for $4 \mathrm{G}$ mobile communications systems (Events E1,3, E1,5, E1,14 and $E 1,15$, see Table 4.2) and they participated in technology trials along with vendors under the LSTI initiative (Event E2,2,1, see Table 4.6). The LTE standard incorporated the service providers' requirements in the standard and achieved confidence of the service provider community in the technology. The value co-creation approach to open 
standard development and adoption may have a significant explanatory power and needs to be further studied.

\section{Standards may differ in the nature of their openness}

There is not a single agreed-upon definition of a standard's openness in the research literature (Krechmar, 2006; Tiemann, 2006). In order to use a specific definition for openness, researchers need to study in advance the specific nature of the standard. 


\section{Conclusions}

This research answers the question: What are the constructs that could be used to describe the convergence to the LTE mobile communication standard? To answer the question, a multi-level, longitudinal case study methodology along with stakeholder analysis was used to examine chronological data about the LTE project and various activities of stakeholders.

Eight multilevel constructs and their constituent dimensions were identified. The results suggest that:

- A field verification of technology based on the standard builds customer confidence in the standard and the lessons learned from verification are valuable to fine-tune the standard.

- Collaboration among stakeholders to participate in proof-of-concept and interoperability trials leading to standards development leads to

- reduction in overall time to complete the standard.

- availability of complementary assets upon commercial deployment of technology.

- reduced time-to-market of standards based equipment.

- Standards dynamics plays a role in technology adoption and convergence.

- Standard's capability to provide interoperability with legacy systems help the standard to gain adoption and even convergence. 
- Technology-neutral alliances among various types of stakeholders accelerate standards development and realization of technology based on standardization.

- Value co-creation characteristics in standards development help in their broad adoption.

\subsection{Limitations}

The research has at least three limitations.

First, the data in this research was collected from web-based sources. Companies were not directly contacted and executive managers of various companies were not interviewed. Data from interviews would have provided additional insights into the motives and risks of different types of companies to participate in the development and adopt the standard.

Second, the study only examines 3GPP release 8 (i.e. LTE). 3GPP release 9 is a maintenance release of the LTE standard and 3GPP release 10 is an enhancement to the LTE standard in the form of "LTE advanced". The case study does not include any activities of stakeholders geared towards these releases.

Third, there is wide adoption from the service provider perspective. Very few service providers have actually awarded commercial LTE contracts to vendors. Due to the end of the timeline of the case study by June 2009, market dynamics and vendor consolidation is not included in the research. 


\subsection{Suggestions for future research}

The following suggestions are made for future research:

- The telecommunication industry has seen lots of consolidation and urge for LTE technology and IPR ownership. Examine if this industry dynamism has impacts on the current state of convergence to LTE and determine if this accelerates the adoption of LTE.

- Till the end of the case study period of this research, the economic slowdown has not impacted the telecommunication market in a visible and significant way. Examine if this has any impacts on commercial deployment of LTE in 2010 and beyond.

- The constructs identified in Table 4.16 are not equal in substance. The constructs and their weight evolve overtime. For example, the construct "Standards dynamics" carried more weight than the "Network effects" during the standard development and convergence timeframe. However, more adoption by additional service providers possibly will shift the weight in favor of "Network effects" construct. This phenomenon can be examined as an extension to this research.

- A systematic way of identifying the links between events suggested by Adomavicius et al. (2007) and Basole (2009) can be deployed to evaluate the LTE standard once a wider deployment occurs and ecosystem starts to build up. 


\section{REFERENCES}

Adomavicius, G, Brockstedt, J C, Gupta, A and Kauffman, R J. 2007. Technology roles and paths of influence in an ecosystem model of technology evolution. Information Technology and Management, 8(2):185-202.

Arnold, G. 2005. Views on Open Standards and Interoperability. ETSI Conference.

Bailetti, A and Callahan, J. 1995. Managing consistency between product development and public standards evolution. Research Policy, 24: 913-931.

Basole, R C. 2009. Visualization of interfirm relations in a converging mobile ecosystem. Journal of Information Technology, 24:144-159.

Choi, B, Raghu, T S, Vinze, A. 2004. Addressing a standards creation process: a focus on ebXML. International Journal of Human-Computer Studies, 61:627-648.

Christensen, C. and Raynor, M. 2003. The Innovator's Solution: Creating and Sustaining Successful Growth, Harvard Business School Press.

Dargan, P A. 2005. Open Systems And Standards For Software Product Development: Chapter 3. Artech House Computing Library. 
De Vries, H, Verheul, H and Willemse, H. 2003. Stakeholder identification in IT standardization processes. In Proceedings of the Workshop on Standard Making: A Critical Research Frontier for Information Systems, eds. King, J. L. and Lyytinen, K, 92107.

Eisenhardt, K.M. 1989. Building theories from case study research. Academy of Management Review, 14(4):532-550.

Eisenhardt, K.M. 1991. Better stories and better constructs: the case for rigor and comparative logic. Academy of Management Review, 16(3):620-627.

Eisenhardt, K.M. and Graebner, M. E., 2007. Theory building from case studies: Opportunities and challenges. Academy of Management Journal, 50(1):25-32.

Hovav, A, Patnayakuni, R, and Schuff, D. 2004. A model of Internet standards adoption: the case of IPv6. Information systems journal, 14(3):265-294.

Kazi, K. 2006. Optical Networking Standards: A Comprehensive Guide for Professionals: Chapter 20.

Krechmer, K. 2006. Open standards requirements. The international Journal of IT Standards and Standardization research, 4(1). 
Moore, G. 2000. Crossing the Chasm: Marketing and Selling High-tech Products to Mainstream Customers. HarperCollins Publishers Inc., New York.

Pettigrew, A.M. 1990. Longitudinal field research on change: theory and practice, Organizational Science, 1(3):267-292.

Pettigrew, A.M., Woodman, R.W. and Cameron, K.S. 2001. Studying organizational change and development: Challenges for future research. Academy of Management Journal, 44(4):697-713.

Rogers, E. M. 2003. Diffusion of innovations, $5^{\text {th }}$ ed., New York: Free Press.

Siggelkow, N. 2007. Persuasion with cases studies. Academy of Management Journal, $50(1): 20-24$.

Tiemann, M. 2006. An objective definition of open standards. Computer Standards \& Interfaces, 28:495-507.

Van de Ven, A.H. \& Poole, M.S. 1995. Explaining development and change in organizations. The Academy of Management Review, 20(3):510-540.

Weick, K E \& Quinn, R E. 1999. Organizational change and development. Annual Review of Psychology, 50:361-386. 
West, J. 2007. The economic realities of open standards: black, white and many shades of gray. Shane Greenstein and Victor Stango, Eds., Standards and Public Policy, Cambridge: Cambridge University Press.

$\mathrm{Xu}, \mathrm{Y} .2007$. Examining the constructs and component dimensions of the OpenAccess project. Masters thesis, Telecommunications Technology Management, Carleton University, Ottawa, Canada, K1S 5B6.

Yin, R K. 2003. Case study research: design and methods, $3^{\text {rd }}$ Edition. Sage Publications.

\section{Web based sources}

3GPP releases, http://www.3gpp1.org/Releases, last accessed on July $2^{\text {nd }}, 2009$.

3GPP specifications, 32 Series, http://www.3gpp.org/ftp/Specs/html-info/32-series.htm, last accessed June $30^{\text {th }}, 2009$.

3GPP specifications, 36 Series, http://www.3gpp.org/ftp/Specs/html-info/36-series.htm, last accessed June $30^{\text {th }}, 2009$.

3GPP working procedures, http://www.3gpp1.org/working-procedures, last accessed on July $10^{\text {th }}, 2009$. 
About LSTI, http://www.lstiforum.org/about/intro.html, last accessed on June $30^{\text {th }} 2009$.

Enabling societal and personal communications for a changing world, page 8 .

http://www.atis.org/webinar/LTEWebinar.pdf last accessed on June $30^{\text {th }} 2009$.

List of the NGMN members, http://www.ngmn.org/aboutus/partners.html, last accessed on June $30^{\text {th }} 2009$.

List of the NGMN sponsors, http://www.ngmn.org/aboutus/partners/sponsors.html, last accessed on June $30^{\text {th }} 2009$.

LSTI members, http://www.lstiforum.org/about//sti membership.html, last accessed on June $30^{\text {th }} 2009$.

NGMN ecosystem working group, http://www.ngmn.org/workprogramme/ecosystem.html last accessed on 30th June 2009.

NGMN FAQ, http://www.ngmn.org/de/aboutus/faq.html, last accessed on June $30^{\text {th }} 2009$.

Open standards: principles and practices, http://perens.com/OpenStandards/Definition.html, last accessed Aug $9^{\text {th }} 2009$. 
Open systems defined, terms \& definitions, http://www.acq.osd.mil/ositf/termsdef.html, last accessed Aug $9^{\text {th }} 2009$.

Overview of the standards process, http://standards.ieee.org/faqs/trainlist.html\#Overview, last accessed on Aug $9^{\text {th }} 2009$.

Wikipedia entry on Coopetition, http://en.wikipedia.org/wiki/Coopetition, last accessed on August $2^{\text {nd }} 2009$.

Wikipedia entry on Sprint-Nextel, http://en.wikipedia.org/wiki/Sprint_Nextel, last accessed on June $30^{\text {th }} 2009$.

Wikipedia entry on UMB, http://en.wikipedia.org/wiki/Ultra_Mobile_Broadband, last accessed on August $2^{\text {nd }} 2009$.

Wikipedia entry on WiMAX, http://en.wikipedia.org/wiki/WiMAX, last accessed on August $2^{\text {nd }} 2009$. 


\section{APPENDIX}

\section{Appendix A: Case study of the 3GPP Long Term Evolution standard}

This appendix depicts a concise case study of the Third Generation Partnership Project's (3GPP) Long Term Evolution (LTE) mobile communication standard. LTE is also referred to as evolved packet system (EPS). LTE deals with the evolutionary step from 3G to $4 \mathrm{G}$ mobile communication systems. The $3 \mathrm{GPP}$ family of standards, i.e. Global System for Mobile communication (GSM), Universal Mobile Telecommunications System (UMTS) and High Speed Packet Access (HSPA), forms the foundation for this new standard. Major benefits for this evolution are higher throughput and lower latency for data access. Lowering the cost per bit of traffic is another value proposition of the standard. LTE enables a richer mobile service environment and provides for the efficient usage of limited available spectrum. Major mobile communication service providers around the world have committed to adopt ${ }^{27}$ the LTE standard. This is going to be a convergence of mobile communication standard after many years of diverse standards deployed in various geographical locations.

LTE is an evolution of the High Speed Packet Access (HSPA+) standard; however, direct evolution from other $3 \mathrm{GPP}$ standards is also possible. Non-3GPP networks can also

\footnotetext{
${ }^{27} \mathrm{http}: / / \mathrm{www}$. intomobile.com/2009/03/08/gsa-confirms-26-operators-committed-to-lte.html, last accessed
} Aug 20th, 2009. 
migrate to LTE. The concept of LTE was first discussed in $2004^{28}$ in the radio access network evolution forum. Standardization goals ${ }^{29}$ were set for various clear targets covering performance, simplified system design, improved use of the radio spectrum and economical targets.

\section{Mobile communication standards}

Initial mobile communication standards emerged in the mid 1980s and were based on analogue technologies like the Advanced Mobile Phone System (AMPS) in North America or the Nordic Mobile Telephone (NMT) deployed in northern Europe. These systems are referred to as first Generation $(1 \mathrm{G})$ mobile communication standards. $1 \mathrm{G}$ standard were based on frequency division multiplexing i.e. each phone call utilizes a separate radio channel.

The second Generation (2G) mobile standards followed and were utilizing digital technologies e.g. D-AMPS with Time Division Multiple Access (TDMA), Code Division Multiple Access (CDMA) and Global System for Mobile communication (GSM) using TDMA. TDMA was relatively better in terms of spectrum utilization and digital transmissions allow for more phone conversations in the same amount of spectrum.

\footnotetext{
${ }^{28} \mathrm{http}: / /$ www.dspdesignline.com/showArticle.jhtml?articleID $=208808450$, last accessed Aug $20^{\text {th }} 2009$

${ }^{29}$ Setting the standard for mobile broadband at the global level, ATIS webinar (http://www.atis.org/PRESS/pressreleases2008/111808.htm)
} 
These digital standards lay the groundwork for newer services like text messaging, sharing content and Internet access through mobile communication.

The third Generation (3G) standards provided more robust technologies and better spectral efficiency. Global mobility and improvement in end-user experience by providing many categories of mobile services are some of the value propositions of $3 \mathrm{G}$ standards. Figure 1 depicts the evolutionary path of $2 \mathrm{G}$ and $3 \mathrm{G}$ technologies and shows that a lot of development on mobile communication standards has happened in the $2 \mathrm{G}$ and $3 \mathrm{G}$ era.

Figure 1: Evolution ${ }^{30}$ of the digital mobile communication standards

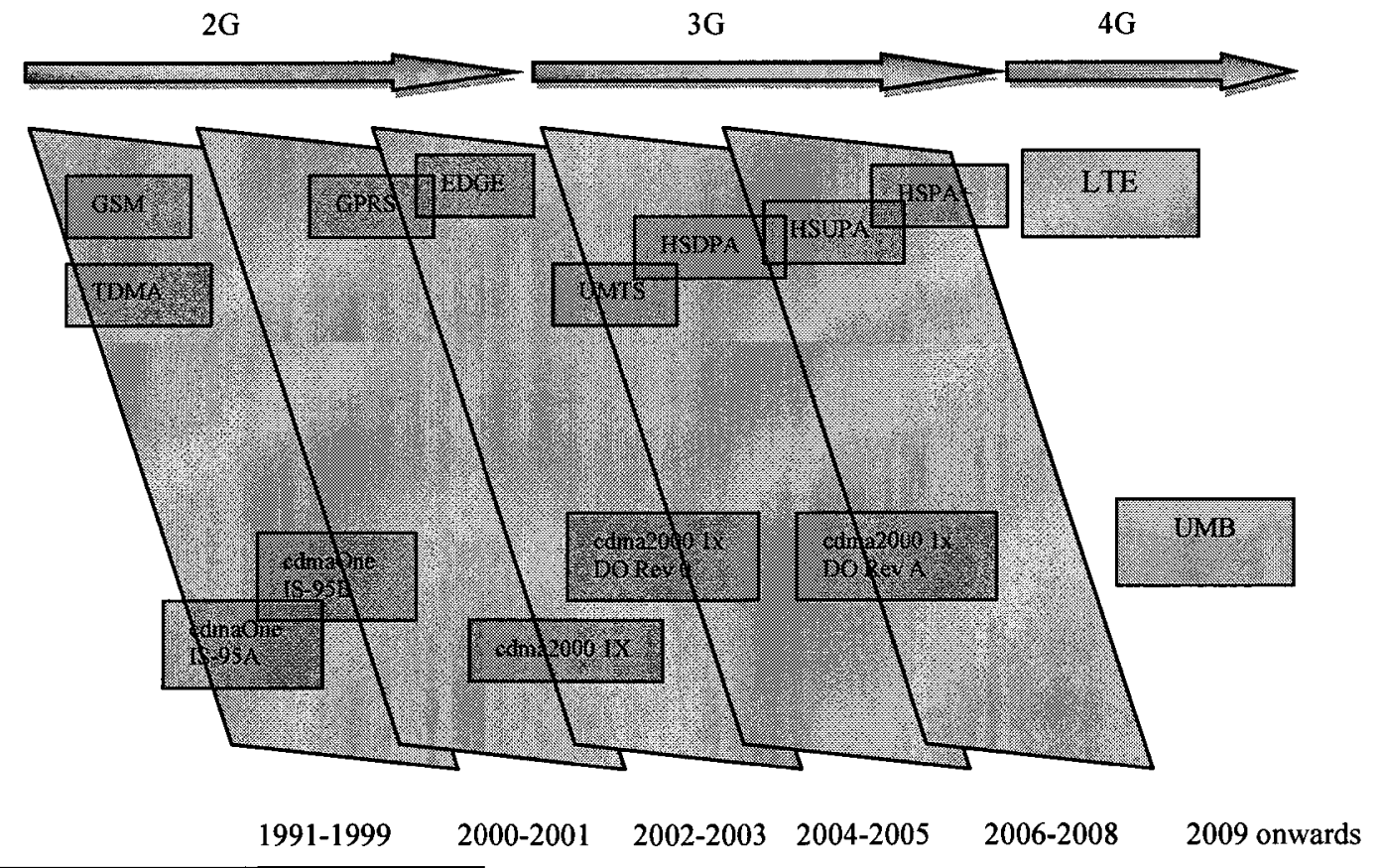

\footnotetext{
${ }^{30}$ Lescuyer, P, Lucidarme, T. 2008. Evolved Packet System: The LTE and SAE Evolution of 3G UMTS. John Wiley \& Sons.
} 
The GSM family of standards i.e. GSM, General Packet Radio Service (GPRS), Enhanced Data rates for GSM Evolution (EDGE), UMTS, High Speed Downlink Packet Access (HSDPA), High Speed Uplink Packet Access (HSUPA) and HSPA+ are the 2G and $3 \mathrm{G}$ standards from the $3 \mathrm{GPP}$ standardization body. The CDMA family of standards i.e. IS-95, CDMA2000/1X, Evolution Data Optimized (1xEVDO) Rev 0, Rev A are the $2 \mathrm{G}$ and $3 \mathrm{G}$ standards from the $3 \mathrm{GPP} 2$ standardization body.

\section{Options for 4G}

Demand for higher data rates and simplified networks is the premise for evolution of mobile communication networks to the $4 \mathrm{G}$ standards. There were three competing standards in this space:

- LTE from 3GPP

- Ultra Mobile Broadband (UMB) from 3GPP2

- 802.16e-2005 (mobile Worldwide Interoperability Microwave Access (WiMAX)) from IEEE

All of the technologies have very similar features, offering high data rates and a similar network architecture. However, they vary in terms of their adoption by various service providers around the world. UMB developments are halted ${ }^{31}$ due to a lack of adoption. WiMAX has gained popularity in the fixed broadband access segment, but adoption by

\footnotetext{
${ }^{31} \mathrm{http}: / / \mathrm{www} . \mathrm{reuters} . \mathrm{com} / \mathrm{article} / \mathrm{marketsNews} / \mathrm{idUSN} 1335969420081113 ? \mathrm{rpc}=401 \&$, last accessed on
} Aug $20^{\text {th }} 2009$ 
mobile communication service providers is much lower. Sprint's $\mathrm{XOHM}^{32}$ service and Clearwire's clear ${ }^{33}$ broadband access services are the most prominent names among the adopters of WiMAX.

The LTE standard has emerged as clear winner among the $4 \mathrm{G}$ mobile communication standards. Major service providers around the world have outlined plans ${ }^{34}$ to adopt LTE as their choice of next generation of service.

\section{Drivers for LTE adoption and development}

Operators, who have been operating their networks for many years now, have learned that in the declining revenue market, reducing the operations and capital expenditure is the way to survive and increase their margins. Innovative and simple mobile communication networks reduce the operational and capital expenditure. Scalable bandwidth, faster throughput and reduced latency for better user experience are the innovation-related attributes; flat network architecture and lower cost per bit are the lower cost attributes of LTE networks. Packetized voice (VoIP) is the attribute covering both dimensions.

\footnotetext{
${ }^{32}$ http://www.xohm.com/, last accessed on Aug $20^{\text {th }} 2009$

${ }^{33} \mathrm{http}: / /$ www.clear.com/, last accessed on Aug $20^{\text {th }} 2009$

${ }^{34} \mathrm{http} / / / \mathrm{en}$. wikipedia.org/wiki/3GPP Long_Term Evolution\#Carrier_adoption, last accessed on Aug $20^{\text {th }}$ 
LTE has emerged as the single most potentially adopted $4 \mathrm{G}$ mobile communication standard. Key drivers for that are:

- Consideration for open ecosystem - There are more than 350 individual members of $3 \mathrm{GPP}$, including major service providers, vendors, chipset providers, User Equipment (UE) providers, test equipment vendors. A coherent view of operators is reflected by Next Generation Mobile Networks $\left(\mathrm{NGMN}^{35}\right)$ contributions. Collaborative technology trials are undertaken by major vendors, chipset providers and UE providers under the umbrella of LTE/System Architecture Evolution (SAE) Trial Initiative $\left(\operatorname{LSTI}^{36}\right)$. LSTI includes service providers' participation in trials and cross-vendor interoperability testing. These trials are done with a global scope.

- Seen as a technology that can be in service for next 10-12 years ${ }^{37}$

- Data hungry mobile applications and services leading to increase in demand for mobile broadband ${ }^{38}$

${ }^{35}$ http://www.ngmn.org/aboutus.html, last accessed on Aug $20^{\text {th }} 2009$

${ }^{36} \mathrm{http}: / /$ www.lstiforum.com/about/intro.html, last accessed on Aug $20^{\text {th }} 2009$

${ }^{37}$ http://www.ngmn.org/nc/news/partnernews/newssingle0/article/t-mobile-cto-ill-invest-in-lte-nothspa.html?tx ttnews[backPid] $=3 \&$ cHash $=34 \mathrm{cf539e}$ e, last accessed on Aug $20^{\text {th }} 2009$

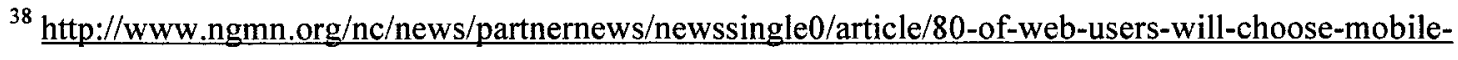
broadband-over-fixed-by-2013-ericsson.html?tx tthews[backPid] $=3 \& \mathrm{cHash}=\mathrm{c} 0 \mathrm{f} 838 \mathrm{c} 0 \mathrm{ea}$, last accessed on Aug $20^{\text {th }} 2009$ 
- Popular devices only support 3GPP standards (e.g. iPhone and iPhone 3G) and in turn driving non-3GPP networks based service providers to converge to the 3GPP standards.

LTE provides a smooth evolution path for existing mobile operators. This is true for operators with existing 3GPP networks and with existing non-3GPP networks (i.e. CDMA $1 \mathrm{x}$ or DO). Figure 2 depicts the evolution path for various standards that are deployed in field.

Figure 2: Evolution path to the LTE

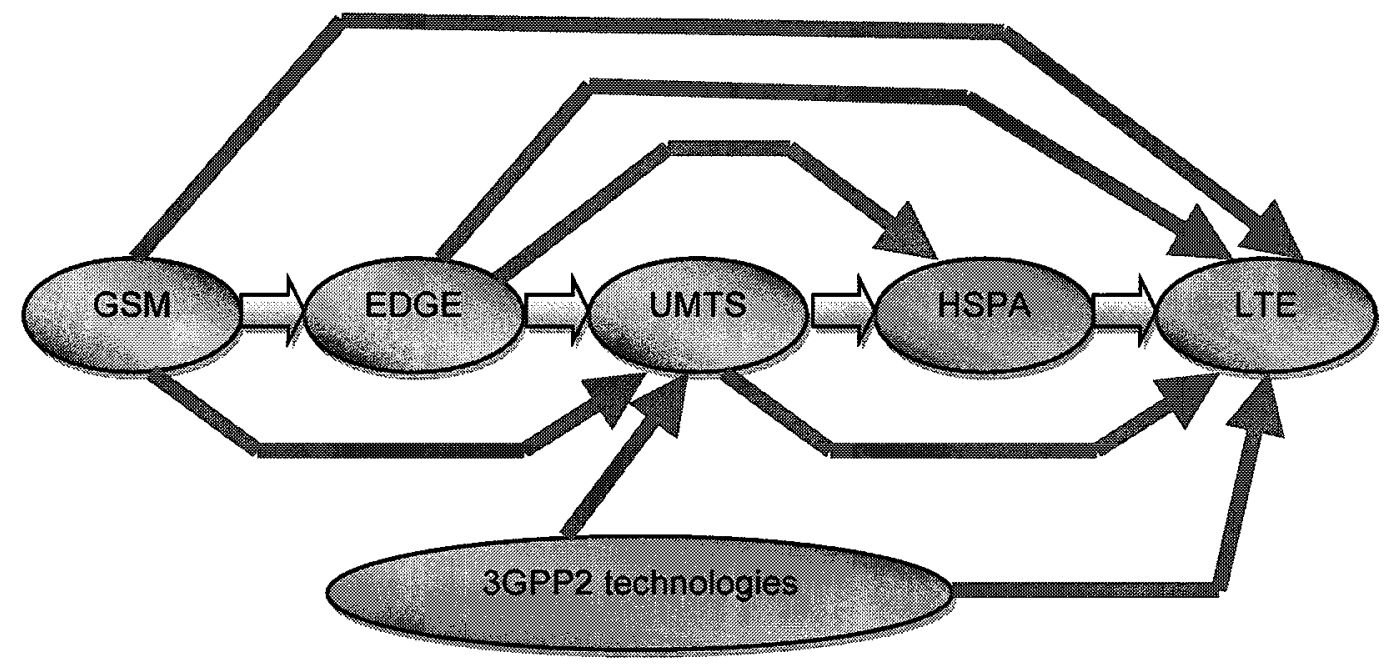

LTE provides seamless integration with $3 \mathrm{GPP}$-based $2 \mathrm{G} / 3 \mathrm{G}$ networks and with $3 \mathrm{GPP} 2$ based $2 \mathrm{G} / 3 \mathrm{G}$ networks and provides seamless handoff to CDMA 1x/DO. This is a driver for worldwide mobile technology convergence and major CDMA operators are choosing LTE as their evolution (e.g. Verizon, Bell, Telus and KDDI). 
Evolved and innovative networks providing high data rates, high spectral efficiency, flexible radio planning, reduced latency, an all-IP environment and self-organizing network capabilities are also drivers for adoption. The push to adopt the LTE standard has happened starting in the middle of 2007. A sample of these events is shown in Table 1.

Table 1: Sample events

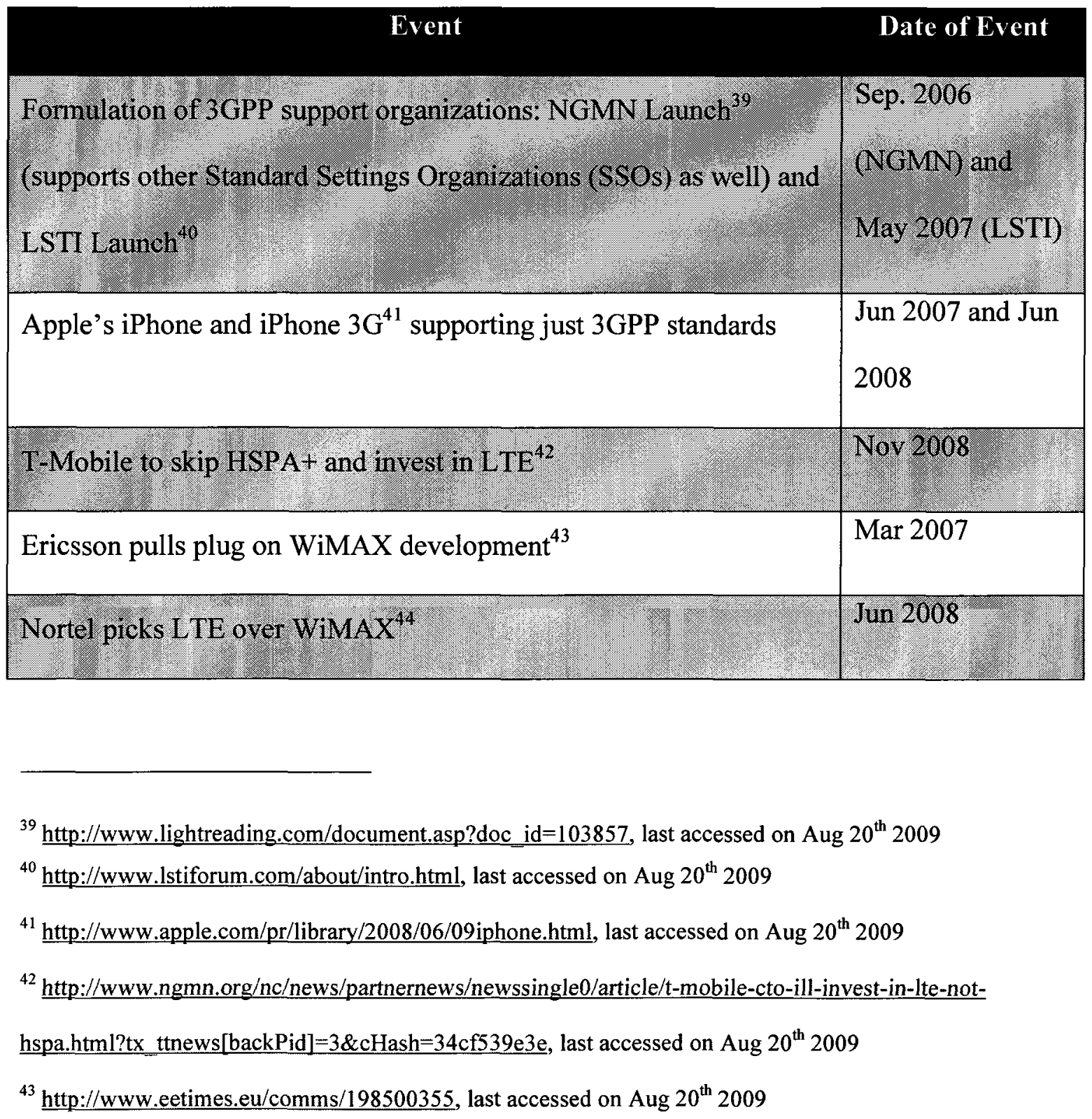




\begin{tabular}{|c|c|}
\hline Verizon selected LTE as its $4 \mathrm{G}$ solution ${ }^{45}$ & Nov 2007 \\
\hline Bell $^{46}$ and Telus ${ }^{47}$ selected HSPA (eventual migration to LTE) & Oct 2008 \\
\hline KDDI to embrace $\mathrm{LTE}^{48}$ & Apr 2008 \\
\hline
\end{tabular}

Similar interest by web users is also reflected by the Google trends ${ }^{49}$ for the keyword $\mathrm{LTE}^{50}$ (depicted in Figure 3).

${ }^{44}$ http://www.pcworld.com/businesscenter/article/146969/nortel picks lte over_wimax.html, last accessed on Aug $20^{\text {th }} 2009$

${ }^{45} \mathrm{http}: / /$ news.vzw.com/news/2007/11/pr2007-11-29.html, last accessed on Aug $20^{\text {th }} 2009$

${ }^{46} \mathrm{http}: / / w w w . b c e . c a /$ en/news/releases/bm/2008/10/10/74991.html, last accessed on Aug $20^{\text {th }} 2009$

${ }^{47} \mathrm{http} / /$ /about.telus.com/cgi-bin/media news_viewer.cgi?news id $=956 \&$ mode $=2 \&$ news year $=2008$, last accessed on Aug $20^{\text {th }} 2009$

${ }^{48}$ http://michi.newsvine.com/ news/2008/04/01/1404313-japans-kddi-to-embrace-lte, last accessed on Aug $20^{\text {th }} 2009$

${ }^{49}$ Google Trends shows how often a particular search term is entered relative the total search volume across various regions of the world, and in various languages. The horizontal axis of the main graph represents time (starting from some time in 2004), and the vertical is how often a term is searched for relative to the total number of searches, globally.

${ }^{50} \mathrm{http}: / /$ www.google.com/trends?q=LTE, last accessed on Aug $20^{\text {th }} 2009$ 
Figure 3: Google trends for keyword "LTE"

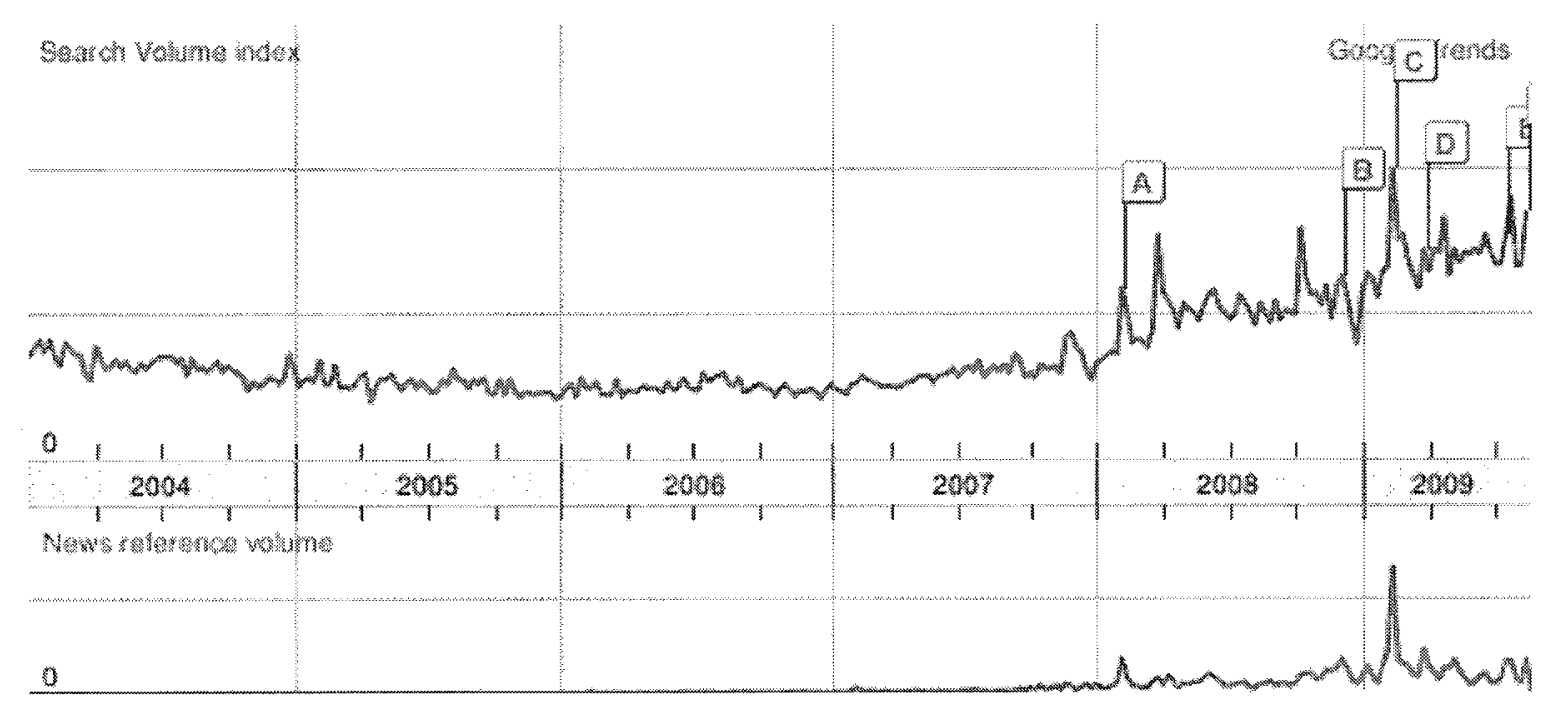

\section{LTE technology and architecture}

The architecture of mobile communication networks consists of a Radio Access Network (RAN) and an Evolved Packet Core (EPC). Evolved Universal Terrestrial RAN (EUTRAN) is another name for RAN. SAE is the name for EPC as well. Collectively, the evolved network is known as Evolved Packet System (EPS). LTE's architecture is depicted in Figure 4. 
Figure 4: LTE/SAE Network Architecture ${ }^{51}$

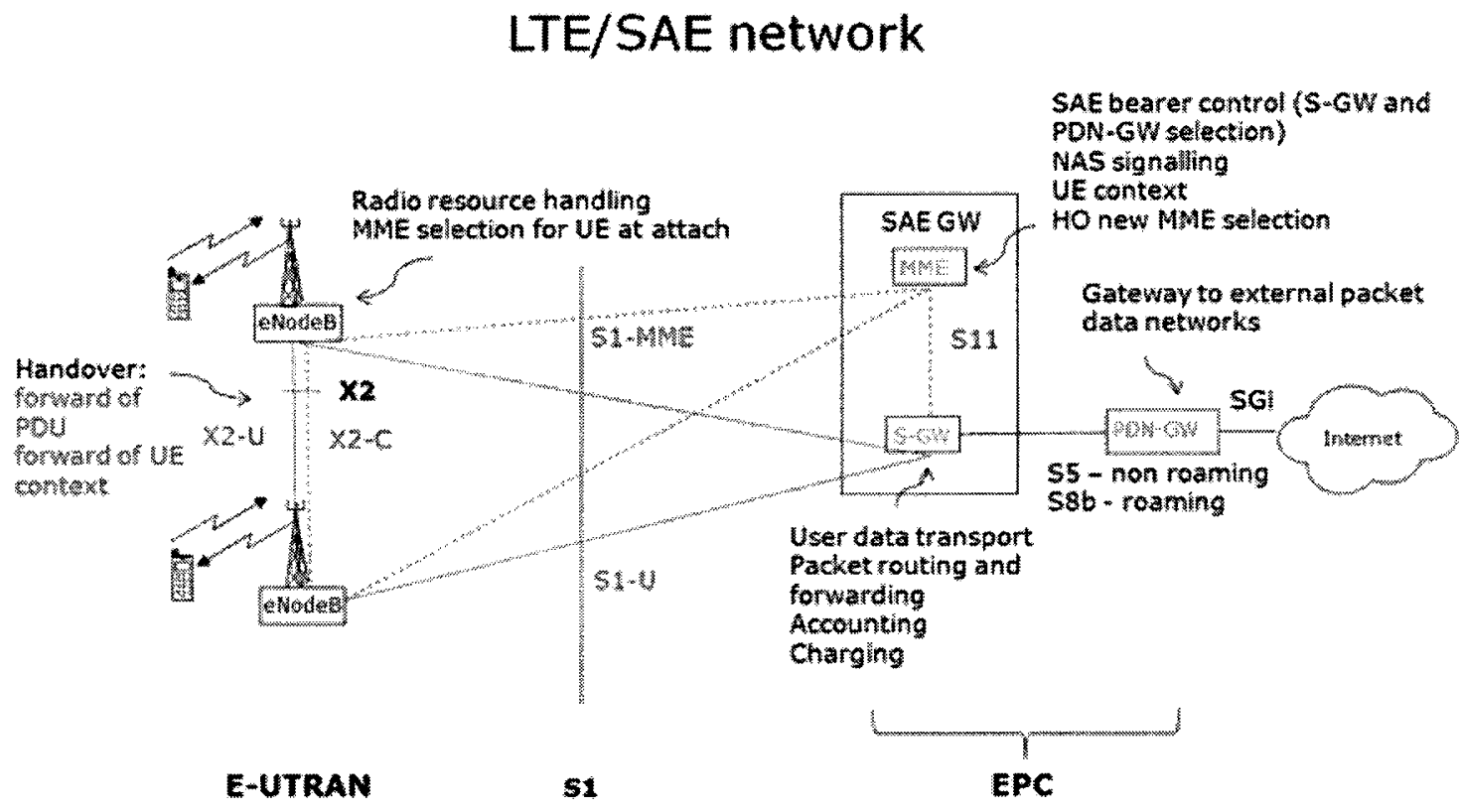

LTE networks have the following attributes ${ }^{52}$ that govern the evolution from existing mobile communication networks:

Enhanced air interface: LTE is built on radio access networks based on Orthogonal Frequency Division Multiplexing (OFDM) technology. The air interface for LTE combines OFDMA-based modulation and multiple access schemes for the downlink, along with Single Carrier Frequency Division Multiple Access (SC-FDMA) for the uplink. All OFDM schemes split the available spectrum into thousands of extremely narrowband carriers, each carrying a part of the signal. In LTE, the innate spectral

\footnotetext{
${ }^{51} \underline{\mathrm{http}}: / / \mathrm{www}$.awaves.com/courseinfo.asp?CourseID=42, last accessed on Aug $20^{\text {th }} 2009$

52 http://www.umts-forum.org/component/option,com_docman/task,doc_download/gid,1904/Itemid,12/, last accessed on Aug $20^{\text {th }} 2009$
} 
efficiency of OFDM is further enhanced with higher order modulation schemes such as 64QAM, and sophisticated FEC (Forward Error Correction) schemes such as tail biting, convolutional coding and turbo coding, alongside complementary radio techniques like MIMO and Beam Forming with up to four antennas per station. The result of these radio interface features is significantly improved radio performance, yielding up to five times the average throughput of HSPA. Downlink peak data rates are extended up to a theoretical maximum of $300 \mathrm{Mbit} / \mathrm{s}$ per $20 \mathrm{MHz}$ of spectrum.

High spectral efficiency: LTE's greater spectral efficiency allows service providers to support more customers within their existing and future spectrum allocations, with a reduced cost of delivery per bit.

Flexible radio planning: LTE can deliver optimum performance in a cell size of up to 5 $\mathrm{km}$. It is still capable of delivering effective performance in cell sizes of up to $30 \mathrm{~km}$ radius, with more limited performance available in cell sizes up to $100 \mathrm{~km}$ radius.

Reduced latency: By reducing round-trip times to $10 \mathrm{~ms}$ or even less (compared with 40 50ms for HSPA), LTE delivers a more responsive user experience. This permits interactive, real-time services such as high-quality audio and videoconferencing and multi-player gaming.

An all-IP environment: One of the most significant features of LTE is its transition to a 'flat', all-IP based core network with a simplified architecture and open interfaces. 
Conversion of the existing core network architecture to an all-IP system is carried out in the LTE standard that enables more flexible service provisioning plus simplified interworking with fixed and non-3GPP mobile networks.

Co-existence with legacy standards and systems: LTE users will be able to make voice calls from their terminal and have access to basic data services even when they are in areas without LTE coverage. LTE therefore allows smooth, seamless service handover in areas of HSPA, WCDMA or GSM/GPRS/EDGE coverage. Furthermore, LTE supports not only intra-system and intersystem handovers, but inter-domain handovers between packet-switched and circuit-switched sessions.

Extra cost reduction capabilities: The introduction of features such as a multivendor RAN or SON help to reduce operation expenditure (OPEX) and provide the potential to realize lower costs per bit.

\section{Self organizing networks}

Mobile networks are becoming ${ }^{53}$ more data centric and are slowly replacing the voicedominant networks of the past. As this shift is happening, the revenue generated from the network is declining. Therefore to generate more revenue and be profitable, operators have to reduce the cost of running the network. Networks with greater capacity but lower

\footnotetext{
${ }^{53} \mathrm{http}: / /$ www.umts-forum.org/component/option,com docman/task,doc download/gid,2089/Itemid,12/, last accesses on Aug $20^{\text {th }} 2009$
} 
costs per bit need to be deployed to handle the future demand for mobile broadband. The roadmap developed by $3 \mathrm{GPP}$ enables operators to do just that - irrespective of their legacy network infrastructure.

The capability to operate the network in a self-organized manner reduces the operational expenditure of operators and hence helps to reduce cost per bit. Self-Organized Networks ( $\mathrm{SON}$ ) is a set of recommendations ${ }^{54}$ put together by the operator community under the umbrella of the NGMN alliance. 3GPP has adopted the recommendation and included them in the LTE standard as TS32.50055. Key features of SON are:

- Automation of neighbour relation lists in LTE and between different 3GPP Radio Access Technologies,

- Self establishment of a new eNodeB in the network,

- Self-configuration and self-healing of eNodeBs,

- Automated coverage and capacity optimization,

- Optimization of parameters due to troubleshooting,

- Continuous optimization due to dynamic changes in the network,

- Automated handover optimization,

- Optimization of QoS-related radio parameters.

\footnotetext{
${ }^{54} \mathrm{http} / /$ www.ngmn.org/uploads/media/NGMN_Recommendation_on_SON_and O M_Requirements.pdf, last accessed on Aug $20^{\text {th }} 2009$

${ }^{55}$ http://www.3gpp.org/ftp/Specs/html-info/32500.htm, last accessed on Aug $20^{\text {th }} 2009$
} 


\section{GPP Standardization body}

3GPP was established in December 1998. 3GPP is a collaboration of various regional and national standardization bodies. $3 \mathrm{GPP}$ refers to the member standardization bodies as “Organizational Partners ${ }^{56, .}$.3GPP’s organizational partners are:

- ARIB (Japan) - Association of Radio Industries and Businesses

- CCSA (China) - China Communications Standards Association

- ETSI (Europe) - European Telecommunications Standards Institute

- ATIS (USA) - Alliance for Telecommunications Industry Solutions

- TTA (Korea) - Telecommunications Technology Association

- TTC (Japan) - Telecommunication Technology Committee

There are more than 350 individual members. Membership in an Organizational Partner is a pre-requisite for Individual Membership of 3GPP. All entities registered as members of an Organizational Partner and eligible for participation in the technical work of that Organizational Partner can become Individual Members of 3GPP if they are committed to support 3GPP and to contribute technically or otherwise to one or more of the Technical Specification Groups within the 3GPP scope. An Individual Member has the right to participate in the work of 3GPP by attending meetings of the Technical Specification Groups and subtending groups.

\footnotetext{
${ }^{56}$ http://www.3gpp.org/partners, last accessed on Aug $20^{\text {th }} 2009$
} 


\section{GPP scope \& objective}

3GPP prepares, approves and maintains the necessary set of Technical Specifications and Technical Reports for GSM/GPRS/EDGE and an evolved 3rd Generation and beyond Mobile System. The original scope of 3GPP was to produce globally applicable Technical Specifications and Technical Reports for a 3rd Generation Mobile System based on evolved GSM core networks and the radio access technologies that they support (i.e., Universal Terrestrial Radio Access (UTRA), both Frequency Division Duplex (FDD) and Time Division Duplex (TDD) modes). The scope was subsequently amended to include the maintenance and development of the Global System for Mobile communication (GSM) Technical Specifications and Technical Reports including evolved radio access technologies (e.g. GPRS and EDGE).

Both service providers and equipment vendors are members of $3 \mathrm{GPP}$ and there is no difference between them concerning membership.

\section{Structure of 3GPP}

3GPP consists $^{57}$ of a Project Co-ordination Group (PCG) and Technical Specification Groups (TSGs). The Technical Specification Groups establish Working Groups as required. Figure 5 depicts the structure of 3GPP.

\footnotetext{
${ }^{57}$ http://www.3gpp.org/specification-groups, last accessed on Aug $20^{\text {th }} 2009$
} 
Figure 5: 3GPP Structure

\section{Project Co-ordination Group (PCG)}

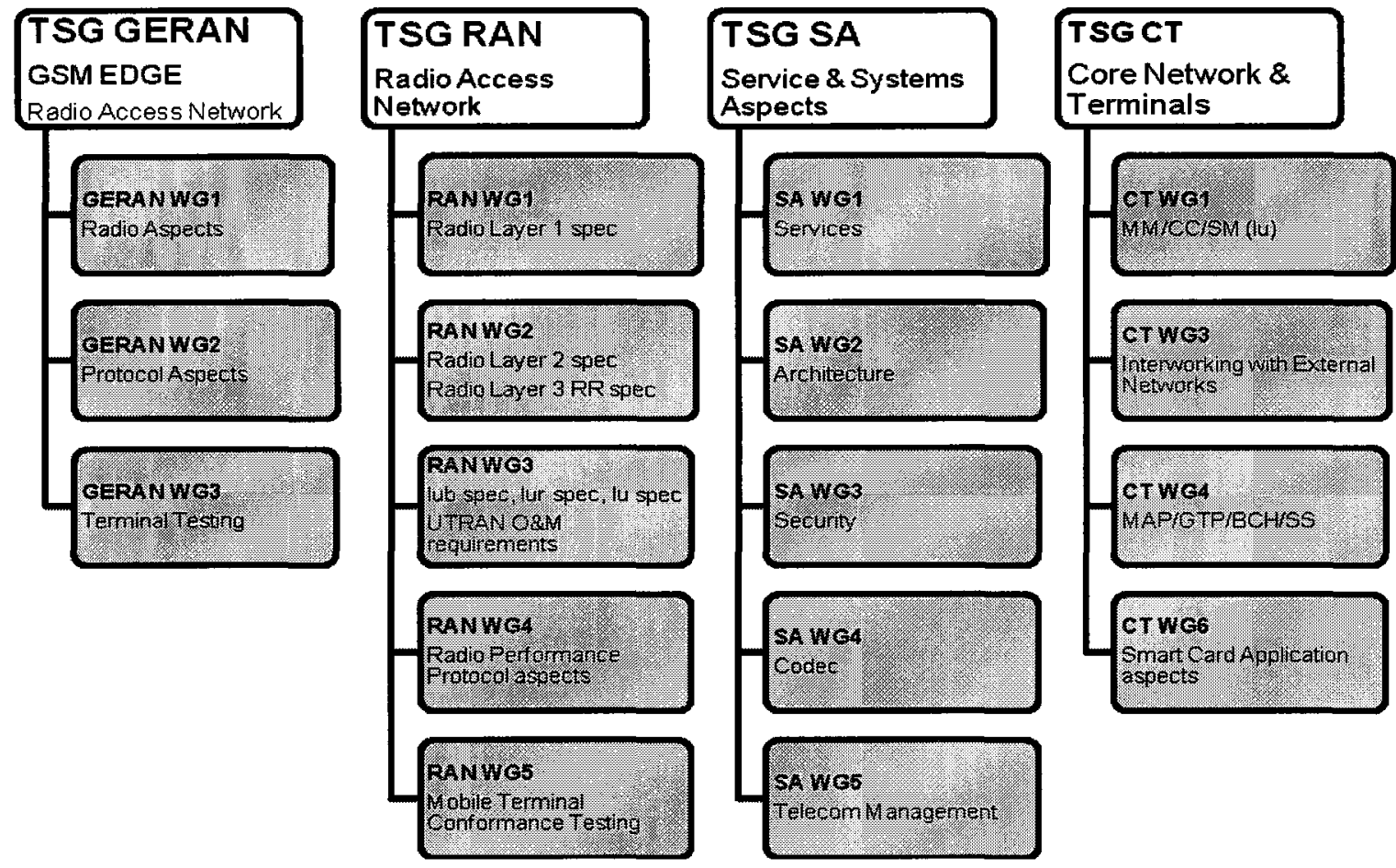

\section{Support Organizations}

3GPP enjoys ${ }^{58}$ the help from certain support organizations that help to define the standards. Next generation mobile networks and LTE/SAE trial initiative are such

${ }^{58}$ ABI Research. 2008. Long Term Evolution (LTE) Network Deployment Strategies, Market Drivers,

Opportunities, and Challenges. 
organizations. Various vendors and operators have come together to facilitate the LTE standard setting by providing recommendations and providing feedback by knowledge gathered during trials.

\section{Next Generation Mobile Network (NGMN) alliance}

NGMN is an alliance of major service providers who are also early adopters of mobile communication technology. Several operators (Sprint Nextel, China Mobile, Vodafone, Orange, T-Mobile International, KPN Mobile, and NTT DoCoMo) formed the alliance in September 2006. Subsequently, NGMN defined the high-level requirements for all nextgeneration broadband wireless networks - not just LTE. This type of initiative is one of the key differences between LTE and its predecessors, which were primarily vendordriven technologies. The NGMN alliance's ${ }^{59}$ mandate is to complement and support the work within standardization bodies by providing a coherent view of what the operator community is going to require in the decade beyond 2010. NGMN has provided 3GPP with recommendations on optimized networks, self organized networks and higher performance networks. These recommendations, which LTE has been developed around, are incorporated into the standards. Another interest of NGMN is to further the mobile ecosystem.

One of the benefits of NGMN is that service providers have buy-in throughout the standardization process. As a result, they will be more comfortable with the standards

\footnotetext{
${ }^{59}$ http://www.ngmn.org/aboutus.html, last accessed on Aug $20^{\text {th }} 2009$
} 
when they are completed and LTE will be optimized for operators. The radio network components will include features to simplify the building and management of the network. Features will include plug-and-play capabilities, self-configuration, and selfoptimization to simplify network rollout and management costs.

In addition to a service providers' role as NGMN members, various types of vendors play the role of sponsors of NGMN alliance's activities. Universities and non-industrial research institutes are also contributing to NGMN's activities in their role of advisors to the alliance.

\section{LTE/SAE Trial Initiative (LSTI) ${ }^{60}$}

LSTI is a global, collaborative technology trial initiative focused on accelerating the availability of commercial and interoperable LTE mobile broadband systems. Major vendors (Nortel, Alcatel-Lucent, Ericsson, Nokia and Nokia Siemens Networks) and operators (Orange, T-Mobile and Vodafone) founded the initiative and have added more stakeholders (chipset vendors, operators and equipment vendors) since its inception. Vendors and operators began testing LTE early in the development process. The test results are shared with operators and 3GPP in an effort to improve the standards as the technology is being defined. Moreover, LSTI collaboration ensures that operators can rely on published results since they participate in the process. LSTI testing helps remove the hype from LTE and make the results more realistic. The efforts of NGMN and LSTI

\footnotetext{
${ }^{60}$ http://www.Istiforum.com/about/intro.html, last accessed on Aug $20^{\text {th }} 2009$
} 
in conjunction with $3 \mathrm{GPP}$ are driving LTE to be a comprehensive technology with early interoperability testing and operator confidence. Objectives of LSTI include:

- driving the industrialization of 3GPP Long Term Evolution and System Architecture Evolution

- demonstrating the 3GPP LTE capabilities

- promoting 3GPP LTE to operators, vendors, analysts and regulators

- simplifying the technology with a full packet-based network and developing newer business models for service providers, vendors and operators

- evolving the 3GPP LTE standard with findings from the proof-of-concept and interoperability trials 